Historic, archived document

Do not assume content reflects current scientific knowledge, policies, or practices. 



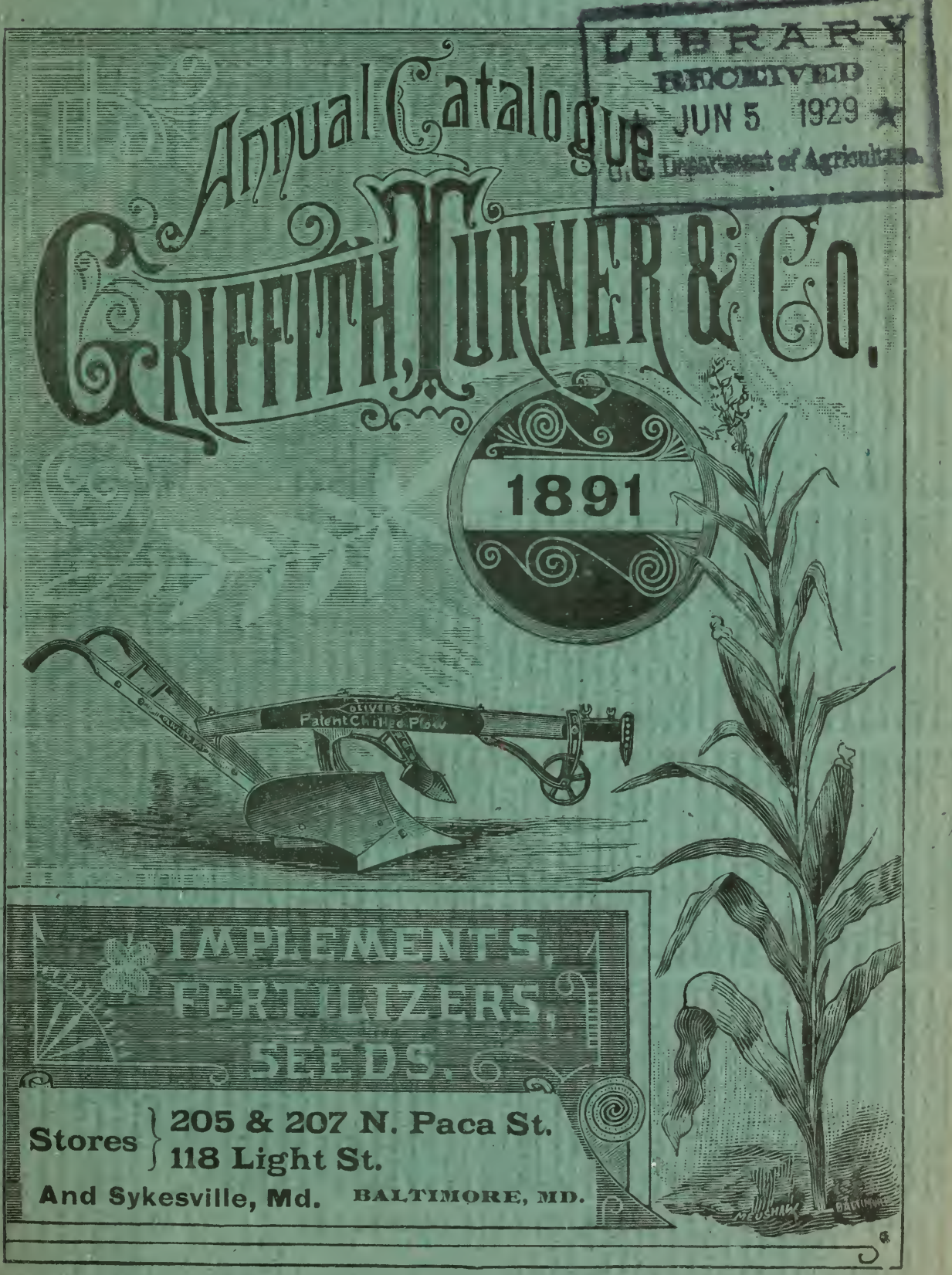




\section{SEED*TABLET.}

\section{THE QUANTITY OF SEED USUALLY SOWN TO AN ACRE.}

Barley, broadcast.........2 to 3 bush. Beans, dwarf in drills.......... $1 / 2$ bush. Beans, pole, in hills ........ 8 to ro qts. Beet, in drills............... to 5 lbs. Broom Corn, in hills. ........4 to 6 qts. Buckwheat, broadcast........ 3/4 bush. Carrot, in drills..............2 to 3 lbs. Corn, in hills................. Corn, for soiling $\ldots \ldots \cdots \cdots \cdots \cdots+\cdots, \cdots$ bush. Clover, Alsike................. ro lbs. Clover, red, alone............... 55 lbs. Clover, red, with Timothy and

Red Top................. Io lbs. Clover, white, alone........... Clover, white, with other seeds...4 lbs. Clover, Lucerne, alone............ Is lbs. Cucumber, in hills............... 2 lbs. Celery, to transplant........... $1 / 2 \mathrm{lb}$. Cabbage, in beds to transplant. ...1/4 lb. Flax, broadcast............. I to 2 bush. Grass, Blue, alone............2 28 Ibs. Hungarian ............. I bush. Lawn .............. Orchard................ 28 lbs. Red Top............... 28 lbs. Rye................ I bush. R. I. Bent ........... " ${ }_{\text {Hemp }} \quad$ Timothy......................... Millet ...................... I bush.
Mustard, broadcast.......... I2 to 16 qte? Mangold Wurzel.................. Oats, broadcast... ......... Onion, in drills ............. Parsnip, in drills............ Peas, Early, in drills........... I bush. Peas, Marrowfat, in drills....... I 1 $/ 4$ bush. Peas, broadcast................. Potato, cut tubers, in drills....... bush. Radish, in drills............. 6 to 8 lbs. Radish, broadcast.............. Rye, broadcast ............... I bush. Salsify, in drills............ 6 to 8 lbs. Sorghum............... 10 to $12 \mathrm{lbs}$. Sainfuin, broadcast.......... I to 3 bush. Spinach, in drills........... I2 to I5 lbs. Sage, in drills............ 8 to ro 1 bs. Squash, (bush varieties), in hills....

................. (running varieties), in hills. .

................. 3 to 4 lbs. Turnip, in drills............... I lb. Turnip, broadcast................ I lb. Tomato, to transplant.......... Vetches, broadcast.......... to 3 bush. Wheat, broadcast......... I I 2 to 2 bush. Wheat, in drills.............. I bush. Clover, together | ro lbs. Clover. Timothy, $\left\{\begin{array}{l}\text { for } \\ \text { I/t bu. Timothy. }\end{array}\right.$ Red Top $\}$ one acre $\left\{\begin{array}{l}\text { I bu. Red Top. } \\ \text { I bu. }\end{array}\right.$

\section{Quantity of Seeds Required of a Given Number of Plants, Number of Hills or Length of Drills.}

Asparagus........... I oz. to $50 \mathrm{ft}$. drill, Beet............... oz to to $50 \mathrm{ft}$. Carrot............... oz. to $150 \mathrm{ft}$. Endive.......... I oz. to $\mathrm{I}_{50} \mathrm{ft}$ : Okra............... oz. to $40 \mathrm{ft}$. Onion.............. I oz. to Ioo $\mathrm{ft}$. Onion sets, small...... q qt. to $20 \mathrm{ft}$. Parsley............. I oz. to I $50 \mathrm{ft}$. Parsnip.............. I oz. to $200 \mathrm{ft}$. Radish............. oz to $100 \mathrm{ft}$. Salsify............. I oz. to $70 \mathrm{ft}$. Spinach............. oz to roo ft. Turnip............ oz. to I $50 \mathrm{ft}$. Peas............. I qt. to $100 \mathrm{ft}$. Dwarf Beans.......... Leek............... I oz. to Ioo ft.
Pole Beans. ......... I qt. to I5o hills.

Corn............... q qt. to 200

Cucumber............. I oz. to 50

Wiatermelon........ I oz. to 30

Muskmelon ........... oz. to 60

Pumpkin............ oz to 40

Early Squash......... oz. to 50

Marrow Squash.. ..... oz. to I6

Cabbage............. oz. to 2000 plants.

Cauliflower........... oz. to 2000

Celery.............. oz. to 3000

Egg Plant ............ oz. to 1000

Lettuce............. oz. to 3000

Pepper............. oz. to rooo

Tomato............. oz. to I 500 
For the convenience of our customers who come to Baltimore by Steamer, or who have not the time to visit our Paca Street Store, we have established a Branch House at No. 118 Light street, in charge of one of the firm, Mr. George W. HobBs, who shall be glad to see you.

Have also secured the services of Mr. Peter Scully, who has been identified with the Seed trade during the last twenty-seven years. Mr. Scully was for a long time in the employ of the old firm of R. SinclatR \& Co., and has since that tinie devoted himself to the Seed and Agricultural Implement business.

Shall be pleased to have you call and examine our line of goods.

We wish to say further that we are offering an entire new stock of Seeds, selected from none but reliable growers.

Full line of Agricultural Implements, Wagons, Buggies, Road Carts and Fertilizers, a description of which will be found on the following pages. 
, 


\section{$T O O U R P A T R O N S^{\prime}$}

In reviewing our last year's business, we desire to state to our customers that the result has been most gratifying; the associations have been pleasant and the goods in return have been satisfactory.

Our Mr. John M. GRIfFith made his usual visit to our Seed farmers, both in the United States and Canada, in order to see the growing crops, and we feel assured that we are offering the best Seeds to be obtained.

Our Mr. M. S. GRIFFITH also visited a number of leading Agricultural Implement Manufacturers, in order to secure some special agencies and at the same time to familiarize himself with the construction of our goods. Owing to the extremely low prices being quoted by some manufacturer: and dealers, it is absolutely necessary that they make and handle correspondingly cheap goods; and since we have always claimed to sell the best of everything in our line, we propose to keep them up to that standard.

Our Fertilizer trade has been all that we could ask; and the greatly increased business is an evidence that our customers appreciate the quality of the goods.

We shall continue to offer a line of Carriages, Buggies and Road Carts, as low as any other first-class house in the trade.

Trusting that our past relations are a guarantee of future fair dealing, we remain, 


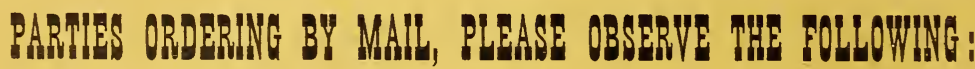

SEEDS, POSTAGE FREE.-Seeds in our 5 and to cent flat papers, ounces and $1 / 4 \mathrm{lb}$. packages, will be mailed Free of Postage to the purchaser.

SEEDS BY MAIL on which the purchaser must pay the postage. Peas, Beans and Corn, 8 cts. per pint. Small Seeds in quantities over $1 / 4 \mathrm{lb}$., $8 \mathrm{cts}$. per $1 \mathrm{~b}$.

REMITTA NCES. Remit by check, draft, postal money-order or postal note ; or, if under One Dollar, in postage stamps.

NOTICE. The greatest care is taken to supply every article true to name and of the very best quality, at the same time it is understood that we do not warrant our seeds and that we are not in any respect responsible for any loss or damage arising from any failure thereof.

On account of short crops in some varieties of Seeds, Prices are subject to change without notice. ASPR1'2015. Sow the seed in the seed bed late in the Fall or in the early Spring, as soon
one inch deep. Thin the plants to ground can be worked, in drills one foot apart, covering the seed about
bed when one or two years old.

Conover's Colossal.-The largest variety grown. Pkt. 5 cts.; oz. 10 cts.; $1 / 4$ lb. 20 cts.; 1 b. 45 cts. Asparagus Roots.-In season.

BeanS. DWARF, SNAP OR BUWM. Select light warm soil and plant, when danBer from frost is passed, in the Spring, in drills two to two and a half feet apart, dropping the beans about two inches apart in the drills, and cover one inch deep. On account of short crop of Beans, all prices are subject to change without notice.

First in Market.-The earliest of all. Pt. 20 cts.; qt. 35 cts.

Early Yellow Six Weeks.-Very early. Pt. 10 cts.; qt. 20 cts.

Extra Early Red Valentine.-An early form of the old Red speckled. Qt. $25 \mathrm{cts}$.

Red speckled Valentine.-Round pod, tender and prolific. Qt. 20 cts.

White Valentine.-Seed white; very desirable. Pt. 15 cts.; qt. 25 cts.

violet.-Improved round pod wax bean. Qt. 40 cts.

Landreth's scarlet. - A sort come to stay. Qt. 35 cts.

Black Wax.-Yellow pod; early for a snap bean; superior. Pt. 15 cts.; qt. 25 cts.

White Wax.-White pod; among the second early varieties. Pt. 15 cts.; qt. 30 cts.

Improved Golden Wax.-Rich, tender, delicious, early. Pt. 15 cts.; qt. 25 cts.

Pink Eye Wax.-Pt. 25 cts.; qt. 40 cts.

White Cranberry.-Valuable when dry for winter use. Qt. 20 cts.

Royal Dwarf white Kidney.-Pt. 15 cts.; $q$ t. 25 cts.

Dwarf Horticultural.-Very fine. Pt. 15 cts; qt. 25 cts.

\section{POLE OR RUNNING VARIETIES.}

Set the poles three or four feet apart, and plant six to eight beans, with the eyes downward, around each pole, thinning to four healthy plants when they are up. They require the same soil and treatment as the dwarf varieties, with the exception that they crave stronger soil, and do best in a sheltered location.

Giant Wax, Red seed.-Pods long, clear waxy yellow, succulent, teuder, fine flavor. Pt. 25 cts.; qt. 40 cts.; $1 / 4$ bush. $\$ 2.75$.

Southern Prolific. - Suitable for table seventy days after germination. Pt. 20 cts.; qt. 40 cts.

speckled Morticultural, or Cherry.-Very productive; used with or without pods. Pt. 15 cts.; qt. 30 cts.

Cherry.-Great favorite; used with or without pods. Pt. 15 cts.; qt. 25 cts.

Extra Large Lima.-As a shell bean surpasses all in quality. Qt. 40 cts.

Dreer's Improved Lima.-An excellent variety. Qt. 40 cts.

Extra Early Lima.-New variety. Qt. 40 cts.

Regular L,ima. $-Q$ t. 30 cts.

ENGI.ISH BEANS. Broad Windsor.-Matures in fifty days after germination. Pt. 20 cts.; qt. 35 cts. 


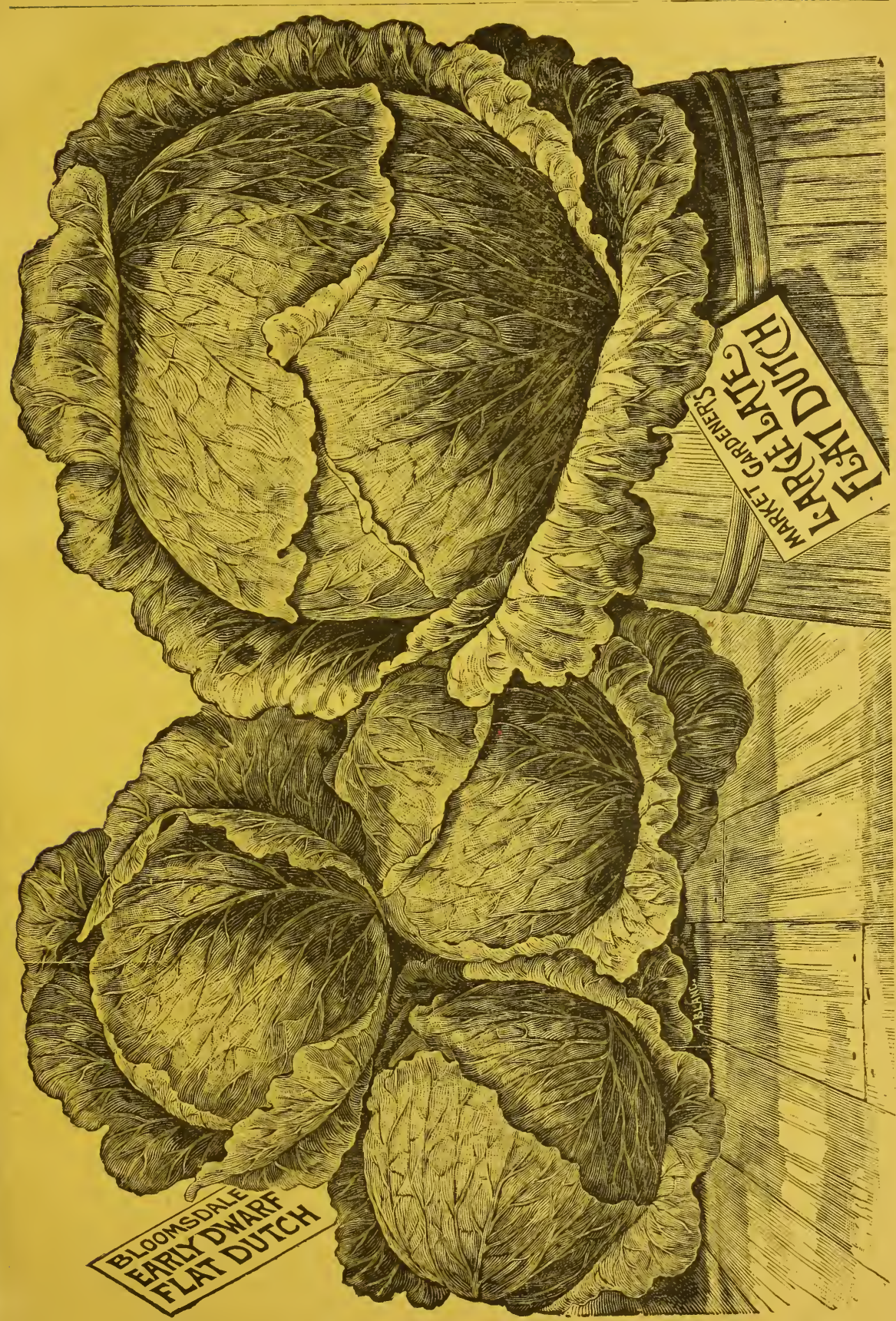


Beet.

Select a deep, rich, sandy loam, and manure with well decomposed compost. Sow in drills, fourteen to sixteen inches apart, and cover one inch deep. When the young plants appear, thin to four or five inches apart. For early use, sow as soon as the ground can be worked in the Spring; for Autumn use, about the middle of May; and for Winter use, from 10th to 20th of June, according to variety; the LNNG varieties requiring more time to mature than the Round EARI.Y kinds. The Mangold Wurzles are grown for stock, and as they grow larger require more room. They should be sown in drills two and a half feet apart, and the plants be thiuned to twelve or fifteen inches in the row. One ounce of seed will sow about one hundred feet of row.

Very Early Forcing.-Pkt. 5 cts.; 0 . 10 cts.; $1 / 4$ lb. 20 cts.; lb. 60 cts.

Ear1y Eclipse Red Turuip.-New, extra early. Pkt. 5 cts.; $0 z .10$ cts.; $1 / 41$ b. 15 cts.; 1 b. 40 cts.

Early Egyptian.-This is a flat Beet, very early and deep red color. Pkt. 5 cts.; oz. 10 cts.; $1 / 4$ lb. 15 cts.; 1b. 40 cts.

Bassano, or Extra Farly Turnip.-Pkt. 5 cts.; oz. 10 cts.; $1 / 4$ lb. 15 cts.; lb. 40 cts.

Early Blood Turnip.-In shape like a turnip, deep red color, and best for general use. Pkt. 5 cts, oz. 10 cts.; $1 / 4$ lb. 15 cts.; $1 / 2$ lb. 25 cts.: lb. 40 cts.

Large Long BIood.-A large and desirable variety. Pkt. 5 cts.: oz. 10 cts.: $1 / 41 \mathrm{lb} .15 \mathrm{cts} . ; 1 \mathrm{~b} .40 \mathrm{c}$.

White Sugar Beet.-A large growing sort and used for feeding stuck. Pkt. 5 cts.; oz. 5 cts.; $1 / 4$ lb. 10 cts.; lb. 30 cts.

Long Red Mangold Wurzel.-A large, long variety, grows well out of ground; color, light red. Pkt. 5 cts.; oz. 5 cts.; $1 / 4$ lb. 10 cts.; lb. 30 cts.

Golden Tankard Mangold.-The best type of Mangold; small top, broad shoulders, smooth, rich skin, very solid fleshed, golden stemmed; heavy producer; the best. Pkt. $5 \mathrm{cts}$.; oz. $5 \mathrm{cts} .1_{1 / 4} \mathrm{lb}$. 10 cts.; lib. 35 cts.

\section{Brussells Sprouts.}

A class of plants allied to the Cabbage family, producing great numbers of small heads for sprouts on the main stem of the plant, which are used in the manner of Cabbage. Plant in rich soil, in hills two feet apart each way. Dwarf Improved. - Pkt. 5 cts.; oz. 25 cts.; $1 / 4 \mathrm{lb} .65 \mathrm{cts}$.

B1. OCCO1. The Broccoli are closely allied to the Cauliflower family. They require similar Early Purple Cape.-Large compact. Pkt. 5 cts.; oz. 20 cts.

Large Early White.-Head, white, like Cauliflower; the best. Pkt. 10 cts.; oz. 35 cts.

\section{Cabbage.}

Cabbage will thrive on any good corn land, though the stronger the soil the better they will develop. New land is preferable. Plow deep and manure very libefrom two to two and a half feet apart. The larger varieties to be from two to four feet apart in the rows, with the rows from two and a half to four feet apart, the distance varying with the size.

King of Ear1y. - Ten days earlier than any uther Cabbage. Pkt. 5 cts.; oz. 25 ets.; $1 / 4$ lb. 75 cts. Landreth's Earliest. -An excellent early sort. Pkt. 5 cts.; oz. 25 cts.; $1 / 4$ lb. 75 cts.; lb. $\$ 2,50$.

Early York.-One of the earliest. Pkt. 5 cts.; oz. 15 cts.; $1 / 4$ lb. 45 cts.; lb. $\$ 1.50$.

Early Summer.-Flat head, the earliest summer variety. Pkt. 5 cts.; oz. 25 cts.: $1 / 4$ lb. 75 cts.

Eariy $\mathbf{M a r l z e t . - L a r g e ~ e a r l y ~ r i p e n i n g ~ v a r i e t y . ~ P k t . ~} 5$ ets.; oz. 30 cts.; $1 / 4$ lb. 75 cts.: 1 b. $\$ 2.75$.

Select Very Early Jersey Wakefield.-Wonderfully fine. Used very extensively by market gardeners. Pkt. 5 cts.; oz. 25 cts.; $1 / 4$ lb. 70 cts.; lb. $\$ 2.50$.

Early Winningstadt.-Head large, cone shaped and solid. Pkt. $5 \mathrm{cts} ., 0 z .15 \mathrm{cts} . ; 1 / 4 \mathrm{lb} .35 \mathrm{cts}$. 1b. $\$ 1.25$.

Reedland Early Drumhead (Frnst EARLY.)-To any one wanting a Cabbage of reliability, be he Market Gardener, Private Gardener, or amateur, we recommend the Reedland. Shurt stemmed. flat headed, large and rery early for a flat headed sort. In all locations a favorite variety. and recommended by all experienced Cabbage growers It will do for first, second and third early, in termediate and late. Indeed it suits all seasons, all conditions and all wants. Pkts. 5 cts.; oz. 40 cts.; $1 / 4$ lb. $\$ 1.10 ; 1$ b. $\$ 4.00$.

Bloomsdale Early Dwarf Flat Dutch.-A variet 5 which stands the sun and produces fine large heads. Pkt. 5 cts.; oz. 25 cts.; $1 / 4$ lb. 75 cts.; lb. 82.50.

Iarket Fardener's I,arge I-ate Flat nutch-(very choice.) - We cannot praise this stock too highly, we unhesitatingly declare it to have no superior. We have never seen its equal. The head is broad, thick and flat, well covered in by leaves lapping across the centre, outside leaves feathered to the base of the leaf stem. There is no risk in this stock. Pkts. 5 cts.; oz. 35 cts.; 1/4 lb. 95 cts.; 1b. $\$ 3.50$.

Large Late F1at Dutch.-Large and excellent for winter; very extensively grown. Pkt. 5 cts.; oz. $20 \mathrm{cts} . ; 1 / 4$ lb. $50 \mathrm{cts}$; l lb. $\$ 1.75$.

Large Drumlinead.-Solid heads, resembles Flat Dutch. Pkt. 5 cts., oz. 20 cts., $1 / 4$ lb. 50 cts., 1 b. $\$ 1.75$.

Drumhead Savoy.-An excellent rariety of fine quality. Pkt. 5 cts., oz. 20 cts., $1 / 4$ lb. 60 cts., lb. $\$ 2.00$.

(Continued on page 6.)

Special Prices to Canners, Truckers, Gardeners and Farmers buying in large quantities. 


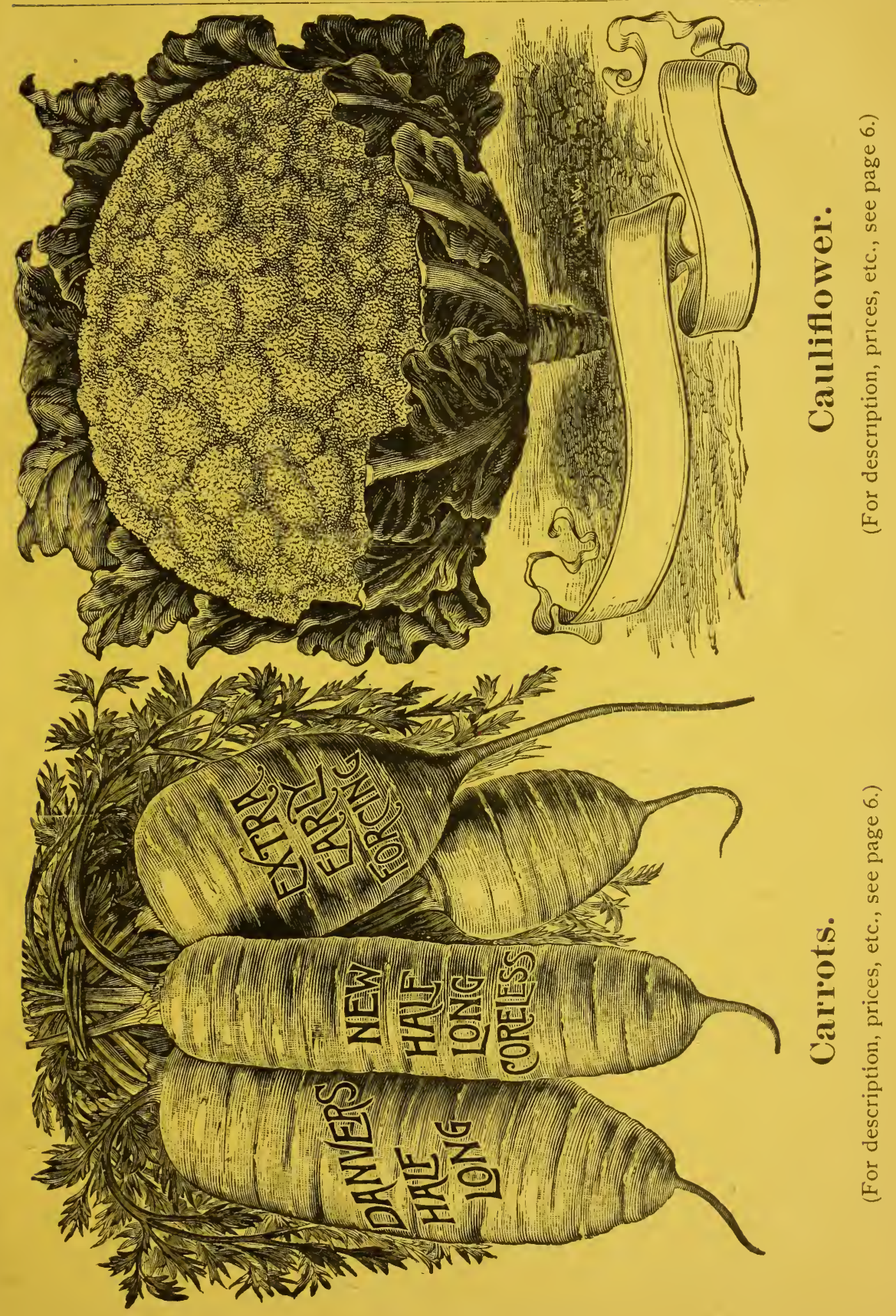


(CA BBAGE.-continued.)

Green Globe or Curled Savoy.-A beautiful rariety of fine flaror. Tery hardy and is improred by frost. Pkt. 5 cts., oz. 25 cts., $1 / 4$ lb. 70 cts., 1 b. $\$ 2.50$.

Red Dutch.--Exclusirely for pickling. Deep purple flat heads. Pkt. 5 cts., oz. 20 cts., $1 / 4$ lb. 50 cts., lb. $\$ 1.75$.

Cauliflower.

The most delicate and delicious of all the Cabbage family and requiring the same culture and treatment: but being more delicate, the good culture and richness of the soil rccommended for Cabbage are absolutely necessary for the Cauliflower. By sowing the early rarieties in the Spring in a hot bed or cold frame, or eren in an open border, they can be obtained in pretty good season.

Select Early Dwarf Erfurt.-Long the standard of highest excellence. Pkt. 20 cts., oz. \$2.25.

Extra Early Paris.-A most excellent early sort. Pkt. 10 cts., oz. 60 cts.

Non pareil.-A standard early rariety, Pkt. 10 cts., oz. 60 cts.

Early Snowball.-Compact, fine for frames and verr reliable for field culture; one of the best for market, gardener or private use. Pkt. 25 cts., oz. \$3.00.

CA110t. Carrots thrise best in rather a light loam. The ground should be well manured CA110t. with fine, well-rotted or composted manure and be thoroughly worked, quite deep. Pla $t$ in rows fourteen inches apart, and thin plants to five or six inches in the row. Plant from middle of $A$ vil to middle of May.

Extra Early Forcing. -Ten days ahead of all others. Pkt. 5 cts., $0 z .10$ cts., $1 / 41 \mathrm{~b} 30$ cts.. $1 \mathrm{~b} . \$ 1.00$.

Early Scarlet Horn.-Blunt rooted, early, good. Pkt. 5 cts., oz. 10 cts., $1 / 41$ b: 25 cts, 1 b. 75 cts.

Orange Danvers, Half-Long.-A decided acquisition of the half-long trpe, broad-shouldered, crlindrical, admirable in color, fixed in habit, a wonderful producer. Pkt. 5 cts., $0 z .10$ ets., $1 / 4 \mathrm{lb}$. 25 cts., lb. 75 cts.

Lc ig Orange.-Deep orange color, long, smooth, fine. Pkt. 5 cts, oz. 10 cts., $1 / 1$ lb. 20 cts., 1b. 70 cts.

H: If-Long (Coreless.)-Pkt. 5 cts., oz. 10 cts., $1 / 4$ lb. 25 cts., 1b. 80 cts. Cele1'y. $\quad \begin{aligned} & \text { Plant seed in hot bed or verr early in open ground. Transplant four inches apart } \\ & \text { when three incles high, in rich soil, finely pulrerized; water and protect until well }\end{aligned}$ ro. ter, then transplant into rows either on suríace or in well manured trenches a foot in depth, half filled wi h well-rotted manure. Set the plants from eight to twelre inches apart. To blanch, draw earth ar. and the plants, from time to time, taking care not to corer the tops of the centre shoots.

White Solid.-A large, standard sort, white and crisp. Pkt. 5 cts., oz 25 cts., $1 / 4$ lb. 65 cts., 1b. $\$ 2.00$.

BC iton Market.--Short, compact and solid; a favorite of many. Pkt. 5 cts., oz. 25 cts., 341 lb. 65 cts.

G: den Heart.-A showy sort, of excellent qualities; one of the best. Pkt. 5 cts., oz. 25 cts., $1 / 1$ lb. 65 it s., 1b. $\$ 2.25$.

Falf Dwarf White.-Pkt. 5 cts , 0 z. 20 cts., $1 / 4$ lb. 60 cts., 1b. $\$ 2.00$.

W vite Plume.-An early, handsome variety. Pkt. 5 cts., oz. 25 cts., $1 / 1$ lb. 65 cts., lb. $\$ 2.25$.

Golden Self-Blanching.-Beautiful golden color; delicious flaror. Pkt. 10 ets., oz. 40 cts.

Celeriac, or Turnip Rooted,-A rariety forming a large, solid root. Pkt. 5 cts., $0 z .20$ cts., $1 / 4 \mathrm{lb} .60 \mathrm{cts}$. Flevoring Celery (Seed.)-For soup. Pkt. 5 cts., $1 / 4$ lb. 10 cts., $1 / 2$ lb. 15 cts, lb. 25 cts.

\section{Corn Salad.}

A favorite salad plant in Europe and rerz hardv. Sown in August, and rery early. Sown in April, it is soon in use. "The leares are sometimes boiled and serred as spinach Pkt. 5 cts., oz. 10 cts., $1 / 4$ lb. 20 cts., lb. 60 cts.

\section{Cor'll--for Table Use.}

On account of short crop of Corn, all prices are subject to change without notice.

Extra Early Baltimore.-The earliest of all. Pt. 15 cts., qt. 25 cts., $1 / 4$ bush. $\$ 1.00$, bush. $\$ 3.50$.

Extra Early Adams.-Pt. 10 cts., qt. 20 cts., $1 / 4$ bush. 90 cts., bush. $\$ 3.00$.

Adams Early.-A farorite in the South. Pt. 10 cts., qt. 20 cts., $1 / 4$ bush. 75 cts., bush. $\$ 2.50$.

Early Minnesota Sugar.-One of the first early among sugar corn. Pt. 10 cts., qt. 15 cts.

Crosby. - Pt. 10 cts., qt. 15 cts., $1 / 4$ busb. 85 cts., bush. $\$ 3.00$.

Cory Sweet White.-Earliest sweet corn known; of superior merit. Pt. 10 cts., qt. 20 cts., $1 / 4$ bush. $\$ 1.10$.

Stowell's Evergreen Sweet.-Excellent; keeps green till cold weather; ear's large; one of the best. Pt. 10 cts., qt. 20 cts.

Mammoth Sweet.-The largest variety grown. Pt. 10 cts., qt. 20 cts.

Egyptian.-Ears long, sweet and tender. Pt. 10 cts., qt. 20 cts.

Landreth.-Remarkably productive, three ears on a stalk; good, try it. Pt. 10.cts., qt. 20 cts.

Black Mexican Sugar. - The Black Corn is especially rich in sugary qualities. Pt. 15 cts., qt. 20 cts.

Special Prices to Canners, Truckers, Gardeners and Farmers buying in large quantities. 


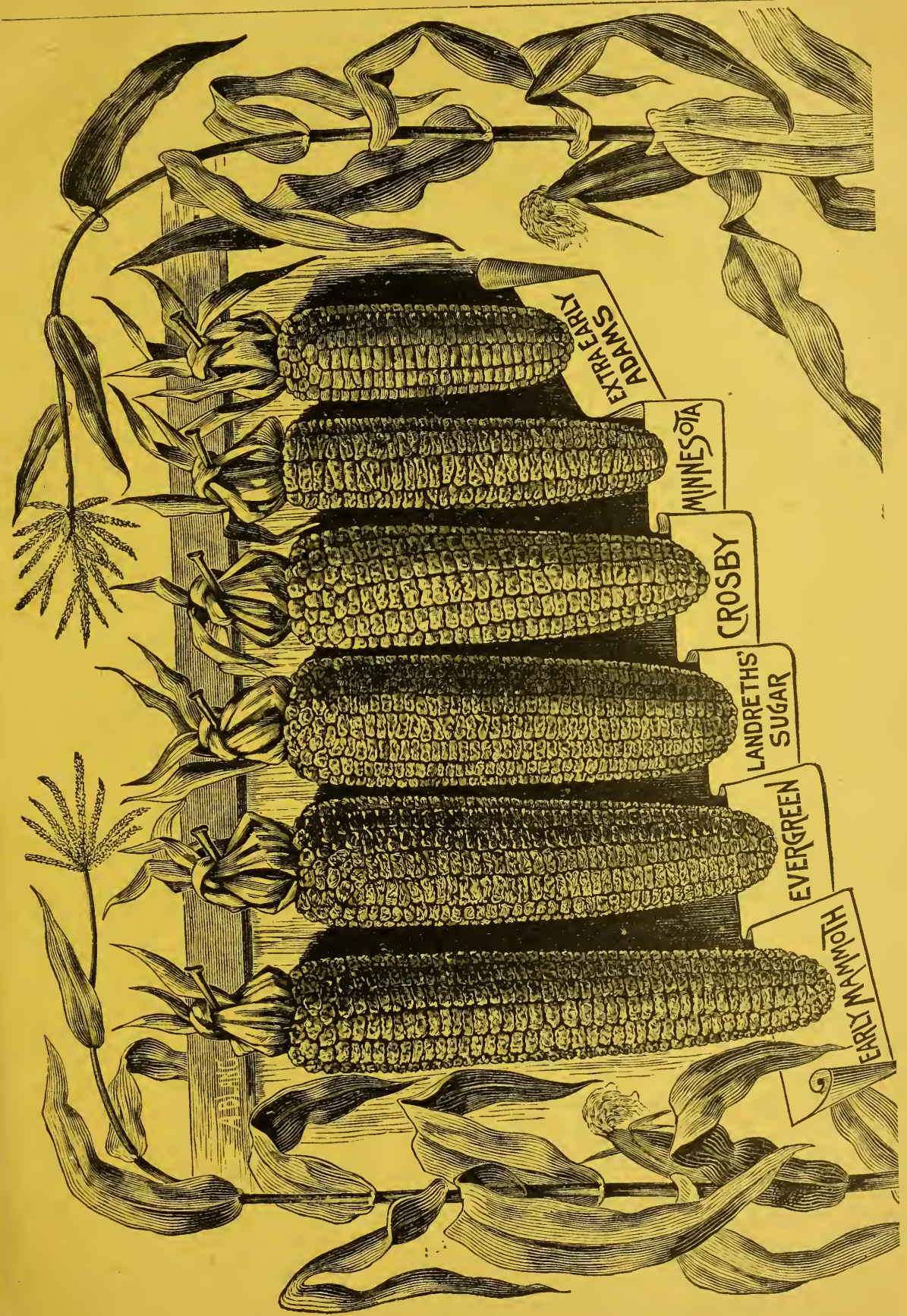




\section{FIELD VARIETIES.}

Maryland White Dent.-Good for meal. Qt. 10 cts., $1 / 4$ bush. 50 cts., bush. $\$ 1.50$.

Improved Maryland Early Yellow Dent.--Stalks medium height; ears large; will produce more than any otber corn. Qt. 10 cts.. $1 / 4$ bush. 50 cts., bush. $\$ 1.50$.

These varieties have taken first premium orer all other Field Corn wherever exhibited.

\section{ADVATTAGES OTER ALL OTHER TARIETIES OF FIELD CORY.}

1. Comes early, strong and rigorous.

2. The fodder grows from seren to ten feet, which does not exhaust the soil.

3. It will stand the drouth better than a large stalk.

4. When dry. fiftr-six years will make one bushel of shelled corn.

5. The grains are unusually deep.

6. This corn will rield fire to ten bushels per acre more than anx other corn generally planted.

7. Fields as good on thin land as any other corn.

s. One bushel will plant five acres and make twenty-fire bushels more than any other corn generaily fianted.

\section{Cress.}

PEPPER GRASs. Tsed as a small salad. Sow rert thickly in shallow drills, on Curled.-Pkt. 5 cts., oz. 10 cts.

Broad-Leared.-Pkt. 5 cts., oz. 10 cts.

Water.-Pkt. 5 cts., oz. 40 cts.

\section{Cucumber.}

The rines require a warm location. Plant after the ground has become larger sorts. Yanure with ashes, in hills four feet apart for the smaller rarieties, and fire feet for the the surface. Sprinkle the rines with plaster or air-slacked lime to protect from bugs.

White-spined.-Great bearer, excellent for early forcing, or for out-door cultivation. Pkt. 5 cts., oz. 10 cts.. $1 / 4$ lb. 20 cts., lb. 60 cts.

Early Frame.-Early, short prolific. Qualiț of fruit good. Pkt. 5 cts., oz. 10 cts., $1 / 4$ lb. 20 cts., 1b. 60 cts.

Long Green.-Superior. For pickles and for market. Pkt. 5 cts., 0 z. 10 cts., 1/1b. 20 cts., 1b. 60 cts. Jersey Pickle.-Said to green better than any other rariety. Pkt. $5 \mathrm{c..} 0 \mathrm{z} .10 \mathrm{c.,} 1 / 4 \mathrm{lb} .25 \mathrm{c} ., 1 \mathrm{~b} .75 \mathrm{c}$. Gherkin.-Burr Cucumber; used for pickles only. Pkt. 5 cts., oz. 20 ets.

\section{Egg Plant.}

Plant the seed in March in a hot bed, or for family use, in flower pots, in warm and settled in rows a warm window. Transplant in upen ground after weather has become tion for warmth as the garden will afford.

Large Round Purple.-Tnsurpassed, purple color and rich flaror; almost thornless. Pkt. 10 cts., oZ. $50 \mathrm{cts} ., 1 / 4 \mathrm{lb}$. $\$ 1.40,1 \mathrm{~b}$. $\$ 5.00$.

New Fork Improved.-This is a form of the old Large Round Purple; large, solid, weighty and showt. Pkt. $10 \mathrm{cts.,}$ oz. 50 cts., $1 / 4 \mathrm{lb} . \$ 1.40,1 \mathrm{~b} . \$ 5.00$.

Endire.

For early use sow as soon as the ground can be worked in the spring. in drills fifteen inches apart, and thin plants to six or eight inches in the row. To blanch the leares gather them carefuliy together when perfectly dry and tie with matting or soft fibrous material. Another method is to invert flower pots over the plant. The leaves are very highly esteemed for use as salads.

Green Curled.- TerJ popular. Pkt. 5 cts., oz. 15 cts.

\section{Kale, or Borecole.}

Plant in hills, two br three feet apart; select deep. rich cur.ed. Tery hardy. Frost improves it. Pkt. 5 cts., oz. 20 cts., $1 / 41$ b. 10 cts., 1b. $\$ 1.50$

Dwarf German Greens, or Sprouts. - This rariety sow in September, broadcast, and gather in early spring, like Spinach. Pkt. 5 cts., oz. 10 cts., $1 / 4$ lb. 20 cts., 1 b. 50 cts.

\section{Kohl Rabi.}

White Tienna.-Bulb light green; flesh white: rers rapid in growth, early in maturity, fine in texture and symmetrical in form. Superior. Pkt. 5 cts., oz. 20 cts., $1 / 4$ lb. 60 cts.

T a T. Select good Onion soil, manure liberally, and plant in April, in drills six to eight inches deep and eighteen inches apart, and thin to nine inches apart, in the drill. Gradually draw the earth around the plants until the drills are filled lerel with the surface. Draw for use in October. To be used in soups, or boiled as Asparagus.

Large Flag.-A large and strong plant; hardy. Pkt. 5 cts., oz. 15 cts. 
Lettuce.

Lettuce covers a rich and rather moist soil. The rows should be about twelve inches apart, and the plants thinned to ten or twelve inches apart for the leading varieties. The more rapid the growth the better the quality. Some varieties are peculiarly adapted for early culture, others for summer growth.

Early Forcing.-The best for hot beds or frames. Pkt. 5 cts., oz. 30 cts., 1/4 1b. 85 ets.

Early Curled Simpson.-Very early, excellent for salads. Form a compact mass of leaves. Pkt. 5 cts., oz. 15 cts., $1 / 4$ lb. 30 cts., 1b. $\$ 1.15$.

Bloomsdale Butter.-Black seed, fine for frames and out-door planting. Pkt. 5 ets., oz. 20 cts.

Large White Cabbage.-Large compact head, very fine, slow to shoot to seed. Pkt. 5 ets., oz. 15 cts. Tennis Ball. - A favorite forcing variety. Pkt. 5 cts., oz. 15 cts., $1 / 4$ lb. 35 cts.

Oak Leaf.-A good, tender, hardy Lettuce. Pkt. 5 cts., oz. 15 cts., 1/4 1b. 35 cts., 1b. \$1.25.

Boston Market.-A celebrated variety in New England. Of good heading habit, small, early and compact; quite desirable. Pkt. 5 cts., oz. $15 \mathrm{cts} ., 1 / 41 \mathrm{~b} .35 \mathrm{cts}$., lb. $\$ 1.25$.

Hanson.-A variation of the India, forming a half closed head. Pkt. 5 cts., oz. 15 cts., $1 / 41 \mathrm{~b} .35 \mathrm{cts}$. MO1011. Select warm and light soil-a poor light soil is better than a cold and rich one. the hills six feet apart for the musk varieties, and eight or nine for Watermelons.

\section{CANTEIOOUPE; MELON.}

Haltimore Mnrket.-Large, thick, green sweet flesh. Pkt. 5 cts., oz. 15 cts.

Extra Farly Hnckensack-Netted, green, flesh and excellent. Very showy, market variety. Pkt. 5 cts. oz. 10 ets.

Nutmeg.-Is one of the best old varieties. Pkt. 5 cts., oz. 10 cts.

Emerald Gem.-Meat salmon color, exceedingly sweet and delicious. Pkt. 5 ets., oz. 10 cts.

\section{WA TER MIEION.}

Kolb's Gem.-Very fine. A good shipper. Pkt. 5 ets., oz. 10 ets., 1/4 1b. 20 ets., lb. 60 cts. Boss Melon.-A new Watermelon of rare quality. Skin dark green. Pkt. 5 cts., oz. 10 cts. lcing. or lce Kind.-One of the best. Very solid, with thin rind. Pkt. 5 cts., oz. 10 cts. Mountain Sweet.-Early, solid, sweet and delicious. Pkt. 5 ets., oz. 10 ets Citron.-Used in preserving. Pkt. 5 ets., oz. 10 cts.

Nastul tum. Plant in May, in rows, the climbing varieties to cover some arbor or 110. fence, or climb, or twine around the house. The leaves are used for salad, and the seeds, when soft enough to be easily penetrated by the nail, for pickles.

Tall.-An ornamental climber. Pkt. 5 cts., oz. 10 cts.

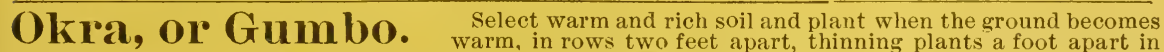
the row. The pods are used to thicken soup, being gathered when young.

Tall.-White, small and round; pods smooth. Pkt. 5 cts., oz. 10 ets., 1/4 1b. 20 cts., 1b. 60 cts.

Prolific.-Very prolific in pods. Pkt. 5 ets., oz. 10 ets., $1 / 4$ lb. 20 ets., lb. 60 ets.

OIIONS. The Onion must have a clean and very rich soil, or it will not do well enough to 011012 . pay for the trouble. Use well rotted manure freely, and be sure to get the seeds or sets in as early as possible in the spring, no matter if it is ever so cold and unpleasant; and keep the soil mellow and elear of weeds, and if seed is good, you will have a large crop of Onions. On no other condition can you hope for success. Disturb the roots of the Onion as little as possible, either in thinning or hoeing, and never hoe earth towards them to cover, or hill, as we do most other things.

Exira Early Red.-Onions of fit size for table use may be raised from the black seed the first season. Pkt. 5 cts., oz. 20 cts., $1 / 4$ lb. 60 cts., lb. $\$ 2.00$.

Sllver Skinned -White, mild flavored, not a good keeper. Pkt. 5 cts., oz. 25 cts., $1 / 4$ lb. 75 cts., Ib. $\$ 2.50$.

Large Red Wethersfield -Pkt. 5 cts., 07.15 cts., $1 / 4$ lb. 40 ets., 1b. \$1.25.

Southport.-White Globe. A large, showy variety. Pkt. 5 cts., oz. 25 cts., $1 / 41 b .65$ cts., 1 b. $\$ 2.25$.

Large Yellow Strasburg.-Very fine. A good keeper. Pkt. 5 cts., oz. 20 cts., 1/4 1b. 50 cts., 1 b. $\$ 1.50$.

Danver's Yellow.-Oval shape, straw color. Good. Pkt. 5 ets., oz. 20 ets., $1 / 41 \mathrm{~b} .50$ cts., lb $\$ 1.40$.

Onion Sets.-From these most of early Onions are raised. (Market prices.)

PI.ST Select rich soil; sow the seed in drills one foot apart, covering half an inch $121^{\circ} \mathbf{S}$. deep. As the seed is usually from fifteen to twenty-five days in vegetating, it will be necessary to sow early. Thin plants to four inches apart when two inches high. The beauty of the plant may be increased by several successive transplantings. It is used principally for flavoring soups, etc., and for garnishing in its natural state.

Fern Leaved.-Pkt. 5 cts., oz. 10 cts., $1 / 4$ lb. 25 ets., $1 b .75$ ets.

Double Curled.-Fine. Beautifully curled. Pkt. 5 cts., oz. 10 cts., 1/4 lb. 20 cts., 1b. 65 cts.

Moss Curled.-A very select, crimpled variety. Pkt. 5 cts., oz. 10 ets., 1/4 lb. 30 ets., lb. 90 cts.

Special Prices to Canners, Truckers, Gardeners and Farmers buying in large quantities. 


\section{Parsnips.}

The Parsnip flourishes test and gires the longest, largest. smoothest roots rions rear. Manure especialls if fresh. makes the roots somerhat ill-shaped. som as early in the spring as the ground can be made reads. pretty thickls, in drills from twelve to eighteen inches apart. and about an inch deep. Thin the plants to tire or six inches apart.

sugar or Hollow Crowned.-The Hollow Crowns are considered superior in qualits to the other rarieties. Smooth, tender and early. Pkt. 5 cts., oz. 10 ets.. $1 / 1$ lb. 15 ets.. 1 b. 50 cts.

\section{Peas.}

The dwarf rarieties should be liberally mancred: the tall sort will run too much to rine riously in good condition. Hare the dwarf, that grow not orer fifteen inches high, in rows two feet apart: those rarieties attaining the height of from two to three feet, in rows three feet apart, and th rows of the tallest sort, four feet apart. Bush the tall kinds when six inches high, or poles, set erery six or eight feet, with single shoe thread passed from one to the other erery lour inches in height. answer finels.

\section{VERY DWARF.}

The rer

American Wonder.-The earliest mrinkled pea. Verr productire and sweet. Pt. 15 cts., qt. 25 cts.. $1 / 4$ bnsh. $\$ 1.50$, bush. 55.00 .

Prenium Gem - An improrement upon the Little Gem. Ters luscious in flaror: try it. Qt. 20 cts., $1_{4}$ bush. $\$ 1.20$, bush. $\$ 4.00$.

\section{DWA RF. Grow about two feet high.}

First Farly Pea.-Earliest of all, and most profitable market yea. Because most nniform in maturity. Pt. 15 cts., qt. 25 ets.. ${ }^{1} \frac{1}{4}$ bush. $\$ 1.25$. bush. $\$ 3.50$

Landweth's Exira Early.-This is a rers early rariety, used largely by market gardeners. Pt. 15 cts., qt. 25 cts., $1 \frac{1}{4}$ bnsh. $\$ 1.25$. bush. $\$ 3.50$

Garden+rs' Favorite.-A mrinkled rariety named and introdaced br ourselres; most delicious flaror: prolific bearer: gite it a trial. Pt. 15 ets., qt. 25 cts., ${ }^{1} 4$ bush. $\$ 1.00$, bush. $\$ 4.00$.

straıg -1 - - l large, wrinkled, blue pea of excellent qualitr: rery long, large well filled pods; one of the best. Pt. 20 ets., qt. 30 ets.. 14 bush. $\$ 1.50$, bush. $\$ 5.50$.

First and [Best.-One of the early rarieties. Qt. 20 cts.

Rumal New Yorker.-In maturity it is among the first early. Qt. 20 cts., 1/4 bush. 75 cts., bush. \$3.

Early Kent, Early May, Daniel U'Ronke. Ac.-Qt. 20 ets., $1_{4}$ bush. 65 cts., bush. \$2.50.

Torkshire Hero.-A wrinkled rariets; productive and of a rers superior flaror. Qt. 20 cts., ${ }^{1} 4$ bush. $\$ 1.00$, bush. $\$ 3.50$.

Adrancer.-A green wrinkled rariets; good. trs it. Qt. 20 ets.. $1 / 4$ bnsh. $\leqslant 1 . n 0, b n \leqslant b . \$ 3.50$.

Improved Dwarf White Marrowfat.-Standard market rariety. Pt. 10 cts., qt. 15 cts.

\section{TALL VARIETIES.}

Champion of England.-An old farorite; rich flarored and rers productire. Pt. 10 ets.. qt. 20 ets.. $1_{4}$ bush. $\$ 1.00$, bush. $\$ 3.00$.

Black-Eyed Marrowfat.-Large pod: prolific. Pt. 10 ets.. qt. 15 cts.

Telephone.-Large wrinkled seeds. Pods large and well filled. Qt. 25 cts.. 14 bus. $\$ 1.50$, bus. $\$ 5.50$.

sugar.-(Edible pods.) Cooked in the pods same as Snap Bean. Pt. 25 cts., qt. 40 cts.

\section{Pepper.}

Capsicnm or Pepper is cuitirated mainly for Pickles. It is nsed as a seasoning in many wars. and sometimes medicinally. sow the seed earls in a hot-bed. if possi ble. if not, select a warm place in the varden for a seed bed. and sonn as the soil is warm. Transplant when three or four inches high.

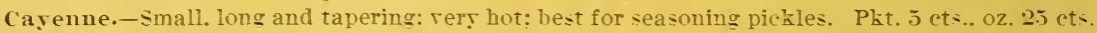
Large sweet Iountain.-Ters large and excellent for Mangoes. Pkt. 5 cts.. nz. 25 cts.

Bull Yose or Bell.-Good for pickling: rery hot. Pkt. 5.cts.. oz. 25 cts.

Golden Bell.-Similar to sweet Spanish. except the color. which is golden. A new introduction. Pkt. 5 cts.. oz. 30 cts.. ${ }^{1}+1$ lb. 75 cts.. 1 b. $\$ 2.75$

\section{Pumpkin.}

The Pumpkin is now rerr little used. except for agricnltural purposes, the

sweet Potato.-Fine flaror. a desirable table sort. Pht. 5 cts.. oz. 10 cts.. 1/4 1b. 25 cts., lb. 75 cts.

Large Cheese.-Skin reddish orange, flesh thick: fine and sweet. Pkt. 5 cts.. oz. 10 cts., 1/4 1b. 15 cts., $1 \mathrm{~b} .50 \mathrm{cts}$.

Cashaw.-solid flesh. fine and sweet: keeps well. Pkt. 5 cts.. oz. 10 cts.. 1/4 lb. 20 cts., 1b. 60 cts.

Connerticut Field.-Good for stock. Pt. 15 cts., qt. 25 ets., 1/4 bush. \$1.25, bush. \$3.50. 

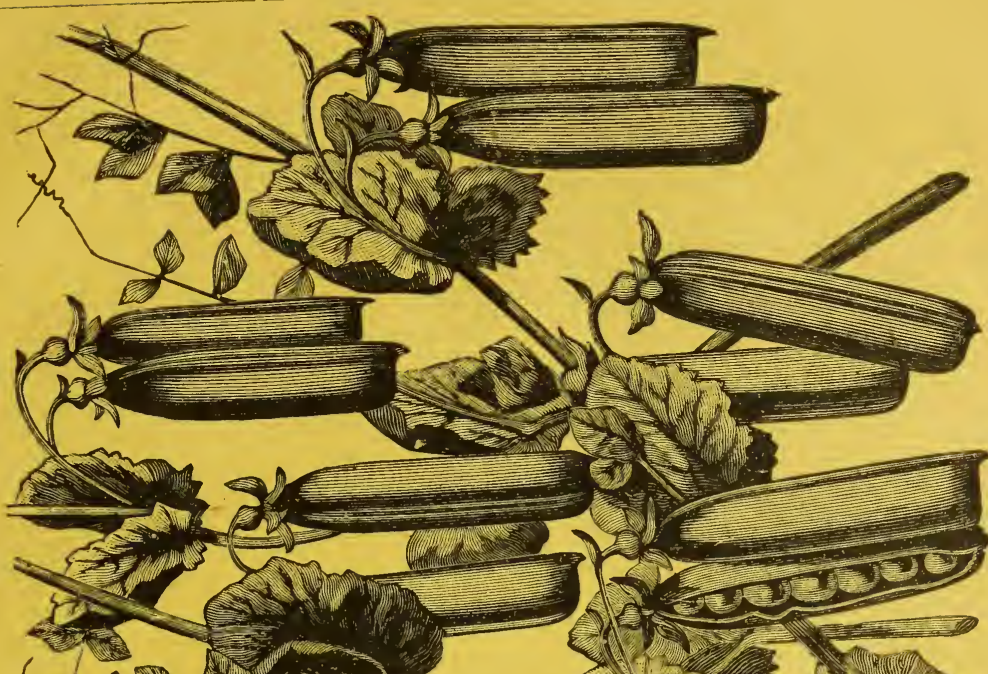

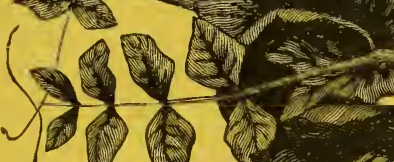

(3)
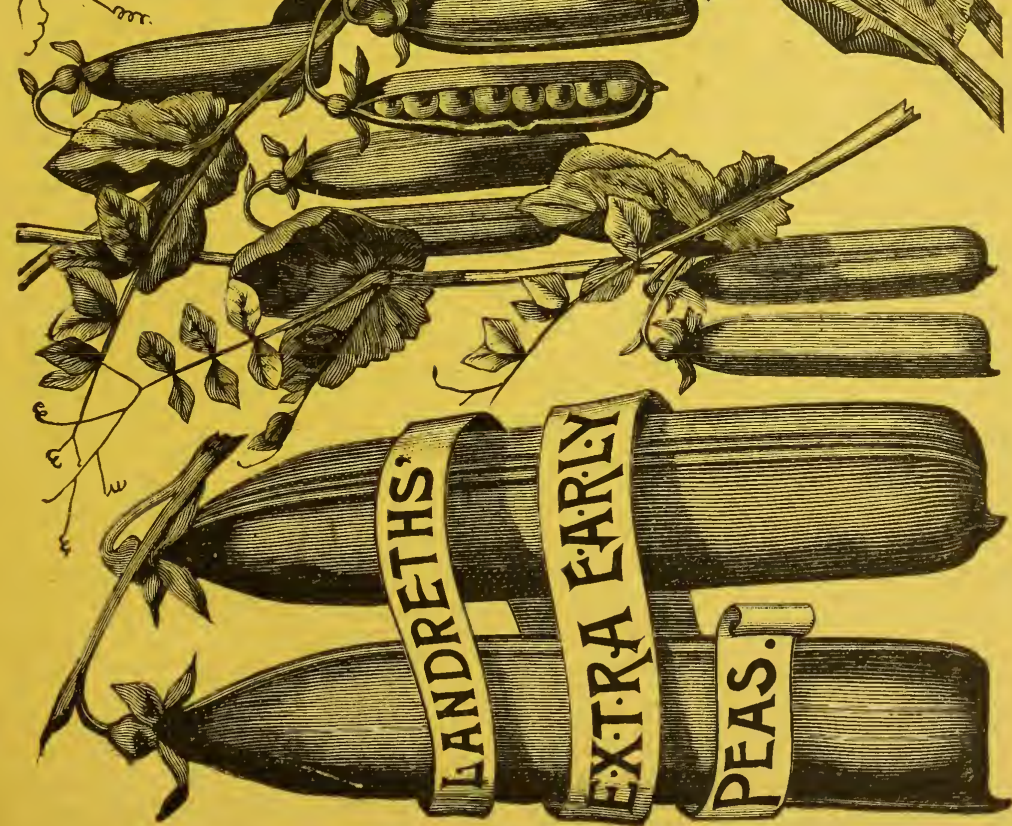
Radish. The Radish must make a rapid growth to be fit for use; it will then be crisp and greeably pungent.

Short-Topped Earliest White Turnip.-For forcing. Pkt. 5 cts., oz. $10 \mathrm{cts}$.

Early Red Turnip.-Turnip-shaped, skin red, for forcing. Pkt. 5 cts., oz. 10 cts.

White Tip Scarlet Turnip.-Red skin, fine flavor. Pkt. 5 cts., oz. 10 cts.

French Breakfast.-Of oval form, color scarlet, white tipped. Pkt. 5 cts., oz. 10 ets.

Long Scarlet.-Short top, deep scarlet roots, crisp, fine. Pkt. 5 cts., oz. 10 cts.

White Summer Turnip.-Fine for Summer use. Pkt. 5 cts., oz. 10 cts.

White Olive.-Quite salable in market. Pkt. 5 cts., oz. 10 cts.

Scarlet Olive Shaped.-Pkt. 5 cts., oz. 10 cts.

Yellow Turnip.-Very desirable for market. Pkt. 5 cts., oz. 10 cts.

Chartier.-Good, new variety. Pkt. 5 cts., oz. 10 ets.

Black Spanish.-Best late variety; black; keeps through the winter. Pkt. 5 cts., oz. 10 cts.

Large White Spanish Winter.-Fine keeping quality. Pkt. 5 cts, oz. 10 cts.

Chinese Rose Winter.-Remarkably fine for winter use. Pkt. 5 cts., oz. 10 cts.

\section{Salsify, or Vegetable Oyster. $\begin{gathered}\text { Sow in early spring, on light, rich } \\ \text { soil in drills, fourtean inches apart }\end{gathered}$} and thin the plants to three inches in the row. The roots will be ready for use in October, and will sustain no injury by being left in the ground during the winter. When cooked the flavor somewhat resembles the oyster, and is a good substitute for it.

White French.-Pkt. 5 cts., oz. 15 cts., $1 / 4$ lb. 40 cts., lb. $\$ 1.25$.

Sandwich Island Mammoth.-Pkt. 5 cts., oz. 20 cts., $1 / 4$ lb. 45 cts., lb. $\$ 1.50$.

Spinach. For summer use sow early in spring, in drills eight inches to one foot apart, cession may be obtained by sowing at intervals of two weeks through the season. For very early spring use, sow in Angust, and protect the plants through the winter by a thick covering of clean straw or some similar light corering. Spinach is used principally as greens for boiling, and is very highly esteemed for this purpose.

Round Leaved.-The popular summer variety. Pkt. 5 ets., oz. 5 cts., $1 / 4 \mathrm{lb} .10 \mathrm{cts}$., $1 \mathrm{~b} .20$ ets.

Bloomsdale Spinach.-(Extra curled.) An improvement upon the Curled Savoy Leaved. Pkt. 5 cts., oz. 10 cts., $1 / 4$ lb. 15 cts., lb. 30 cts.

Long Standing.-Best for spring sowing; slow to seed. Pkt. 5 cts., $1 / 4$ lb. 10 cts., lb. 20 cts.

Squash. The Squashes are all quite tender, and therefore, no progress can be made in ment the same as for Melons.

Early White Bush Scolloped.-A desirable and marketable sort. Pkt. 5 cts., oz. 10 cts.

Summer Crook Neck Early.-Fine flavor, a desirable table sort. Pkt. 5 cts., oz. 10 cts.

Winter Crook Neck.-Flesh red, fine flavor, largely grown for winter use. Pkt. 5 cts., oz. 10 cts.

Boston Marrow.-For autumn use. Fine for pies or baking. Pkt. 5 cts., oz. 10 cts.

Hubbard.-Fine and desirable for winter use. Pkt. 5 cts., oz. 10 cts., $1 / 4$ lb. 20 cts., lb. 70 cts.

Tomat S. Sow the seed in March or April in the hot-bed or in pots, in a sunny exposure 1010210. in the house. If it is desired to make very healthy, stocky plants, they may be transplanted or repotted when about two or three inches high, to dwarf and give them more room. When five or six inches high, if the ground has become warm transplant them to the open ground on a rainy or cloudy day, if possible; if not, the young plants should be liberally watered and shaded from the hot sun. 'T'he richer the soil, the more handsome and plentiful the fruit will be; but if it is desirable to have the fruit ripen as early as possible, select rather light, poor soil and a sunny location. Set the plants four feet apart each way.

A cme.-Of superlative merit, size medium; shape, slightly oval, smooth as an apple. Pkt. 5 cts., oz. 20 cts., $1 / 4$ lb. 65 cts., lb. \$2.00.

Paragon.-Here we have a variety-the perfection of a Tomato-large, solid and smooth as an apple, and deep red. It is superb. No praise can be too high. Pkt. 5 and $10 \mathrm{cts}$., oz. $20 \mathrm{cts}$., $1 / 4 \mathrm{lb}$. 60 cts., lb. $\$ 2.00$.

Trophy.-Large red variety. Pkt. 5 cts., oz. 20 cts.. $1 / 4$ lb. 65 cts., 1 b. $\$ 2.00$.

Queen.-Fruit somewhat resembles Paragon in appearance. Favorite among canners. Pkt. 5 cts., oz. 20 cts., $1 / 4$ lb. 65 cts., 1 b. $\$ 2.00$.

Beauty.-(New.) Very fine; try it. Pkt. 5 cts., oz. 25 cts., $1 / 4$ lb. 65 cts., lb. $\$ 2.00$.

Favorite.-This is a large perfect-shaped Tomato. One of the best. Pkt. 5 cts., oz. 20 cts., $1 / 1 / 2$ lb. 65 cts., lb. $\$ 2.00$.

(Continued on page 14.)

Special Prices to Canners, Truckers, Gardeners and Farmers buying in large quantities. 
TOMATO.-(continued.)

Mikado.-Color purplish red like that of the Acme. Pkt. 5 cts., oz. 20 cts., $1 / 4$ lb. 65 cts., lb. $\$ 2.00$.

Dwarf Champion.-Entirely distinct from any other variety; plant grows stiff and upright; can be planted three feet apart; extra early. Pkt. 5 cts., $0 \mathrm{z} .25 \mathrm{cts.,} 1 / 4 \mathrm{lb} .75 \mathrm{cts}$.

Early Jersey.-Good early variety. Pkt.5 cts., oz. 35 cts.

Peach Tomato.-Second early; resembling peach in appearance. Pkt. 5 cts., oz. 30 cts.

Perfection.-A superb Tomato. Pkt. 5 cts., oz. 20 cts., $1 / 4$ lb. 60 cts., lb. $\$ 2.00$.

Golden Queen.-A bright sellow large, solid : ripening well up to the stem; a good keeper, and, all things considered, the best Yellow Tomato erer introduced. Of enormous productireness. Pkt. 5 c:ts.. oz. 25 ets.. $1 / 4$ lb. 65 cts., lb. $\$ 2.25$.

Pear Shaped Yellow.-Sometimes known as the Yellow-Egg or Plum; used for preserves and pickles, of extraordinary productireness. Pkt. $5 \mathrm{cts}$., oz. $25 \mathrm{cts} ., 1 / 4 \mathrm{lb} .70 \mathrm{cts}$.

Grape, Clerry, or Currant.-Fruit borne in cluster, size of fruit half-inch in diameter, desirable for pickles or preserves. Ornamental. Pkt. 5 and 10 cts., oz. 25 cts.

\section{Turnip.}

For early use, sow the small sorts as soon as the ground can be worked in the spring, in drills fourteen inches apart-the Rutabagas thirty inches. As the seed is rery fine, it should be covered but slightly, excepting in rery dry weather. Select light and, if possiwith insects, a sprinkling of the same will be found beneficial. For fall and winter use, the early kinds should be sown from the middle of July to the middle of August, and the Rutabagas from middle of June to first of July, using from one to one and a half pounds of seed to the acre.

Early Red Top.-(Flat.) Fine, sweet, mild, rapid grower ; very early and pouplar. Pkt. 5 cts., oz. 10 cts.. $1 / 4$ lb. 15 cts., $1 / 2$ lb. 20 cts., lb. 35 cts.

Early White Top.-Differs from Red Top only in color. Pkt. 5 ets., oz. 10 cts., $1 / 41$ lb. 15 cts., 1 b. 35 cts.,

Large Early Red-Top Globe.-A rariety of recent introduction, of large size, rapid growth, unusually attractire and approved and admired by all who have seen it. A very much heavier producer than either of the preceding, and quite as early as the Flat Red-Top. We confidently recommend it as an acquisition. Pkt. $\overline{5}$ ets., oz. 10 cts., $1 / 4$ lb. 15 c.ts., 1 b. 40 ets.

Early White Egg.-A new variety of rapid growth; egg shaped and white, as its name indicates. A sort destined to be in great demand. Pkt. 5 cts., oz. 10 cts., $1 / 41$ b. 15 cts., lb. 40 ets.

Yellow Aberdeen, or scotch Yellow.-This is a highly approved CATTLE TURNIP. attaining a large size. It is solid. nutritious, a good keeper and in every respect reliable. Pkt. 5 cts., oz. 10 ets.. $1 / 4$ lb. 15 c.ts., 1 b. 40 ets.

A mber Grobe.-Pkt. 5 ets., oz. 10 ets., $1 / 4$ lb. 15 ets., lb. 40 ets.

\section{Rutabaga, or Swede Turnip.}

Improved Purple Top Rutabaga.-A standard field variety for stock, and fine for family use. Yellow fleshed. Pkt. 5 cts., oz. 10 ets., $1 / 4$ lb. 15 ets., $1 / 2$ lb. 25 cts., lb. 40 cts.

Sweet and Pot Hel'bs. A little collection of sweet Herbs is a treasure to will gire all the herbs needed in any family. Cut when in flower; dry in the shade.

Sage.-American. Pkt. 5 cts.; oz. 20 cts. Thyme.-Broad Leaved English. Pkt. 5 cts. Summer Savory.-Pkt. 5 cts. Sweet Basil.-Pkt. 5 cts.

Sweet Marjoram.-Pkt. 5 cts. ; oz. 20 cts. Coriander.-Pkt. 5 cts. Chervil. - Pkt. 5 cts.

Grass and Clover Seed.

Red Clorer. White Clorer. Perennial Rre Grass. Hungarian Grass. Timothy and Red on application. 


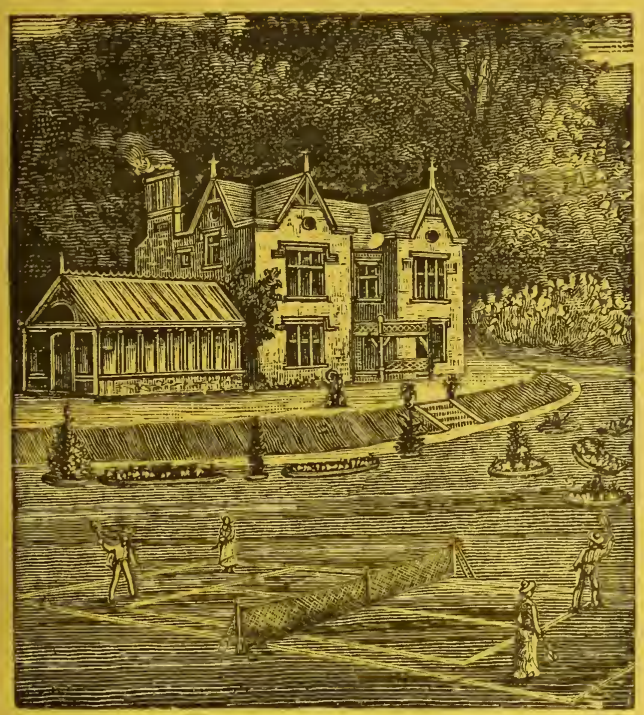

\title{
OUR SPECIAL
}

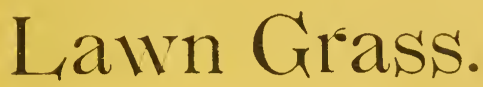

A first-class mixture prepared by ourselves and contailing nothing but choice seeds; extensively used on lawns in this vicinity, with the most satisfactory results. Qt. 25 cts., $1 / 4$ bush. $\$ 1.25$, bush. $\$ 5.00$.

We also have a cheaper grade of lawn grass which does not contain some of the high priced varieties to be found in the above special mixture, however this article makes a beautiful sod. Qt. $20 \mathrm{cts}$., 1/4 bush. $\$$ I oo, bush. $\$ 3.00$.

\section{Hammond's Slug Shot.}

The great merit of this insecticide lies in its non-poisonous properties ; no danger need be apprehended by the person applying it, nor will it injure animals should they eat it, unless in large quantities. It does not render injurious the vegetables or fruits on which it is applied, and yet it is probably the best insect destreyer that has ever been offered. It is particularly useful for the prevention and destruction of potato bugs and all worms and insects that infest our gardens. It comes all ready to be applied : there is no mixing with plaster or flour, no dissolving in water; it is simply dusted lightly on so that it reaches all parts of the plant. It will be necessary, however, to apply it occasionally, for it does not kill the eggs or prevent them from hatching. The best time to apply it is early in the morning, particularly for potato bugs, as they do not feed during the night. 'The quantity of Ilammond's Slug Shot needed for the acre varies accorling to the number and size of the plants, from ten to forty pounds. For further information send for little book on Slug shot. Prices: 10 lb. packages for 50 cts., $5 \mathrm{lb}$. packages for 25 cts. Special prices on large quantities in bulk.

\section{PARIS GREEN, in any Quantity, at Lowest Prices.}

\author{
ERB'S HORSE AND CATTLE POWDERS,
}

RUST EGG PRODUCER,

HAVEN'S ROOP PILLS,

\section{HAVEN'S CLLMAX CONDITION POWDERS, for Cattle and Poultity.}




\section{$\rightarrow$ FERTILIZERS}

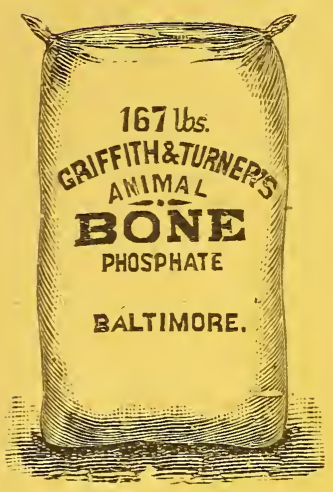

ANIMAL BONE PHOSPHATE.

The old reliable; a favorite with Truckers as well as Grain Farmers.

Where quick and permanent action is required it stands as one of the most popular brands in use. A complete Fertilizer, combining all of the necessary elements of Plant Food.

As a Truck Fertilizer it has but few equals, and we refer to the following well-known Farmers and dealers:

J. M. GILlESPIE, Rossville, Baltimore Co., Md.

ROBT. IV. CHARD, Armiger, Anne Arundel Co., Md.

O. S. PUMPHREY, Marley, Anne Arundel Co., Md.

IVILSON S.ANITARIUM, Mt. Wilson, Balto. Co., Md.

And many others.

\section{Price, - - \$32.00 per Ton.}

\section{ALKALINE PLANT FOOD.}

Prepared especially for Corn, Oats, Potatoes, and Summer crops generally. As a Potato Fertilizer this article has a reputation of many years' standing, and our greatly increased sales each year justify us in making the claims that we do for it. We use nothing but first-class materials and give you in the "PLANT FOOD" just what the Potato and other Summer crops require ; as its name implies it is a reliable plant food. The results obtained from the above on Celery alone are worthy of mention, and we have never seen it used for that plant without the most flattering results.

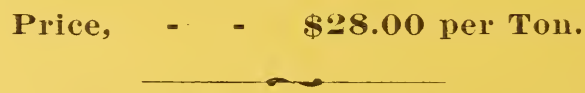

\section{SOFT GROUND BONE.}

Made from soft stock; becomes soluble in a short time; acts quickly with the best results; the cheapest Bone made. If you believe in Bone, try this brand, it will pay you. Ever increasing sales and popularity. 


\section{No. I DISSOLVED BONE.}

Sales for 1890 far ahead of any previous year. Made from Soft Bone, dissolved. Contains some blood and meat; try it and you will always use it.

Price, - - \$28.00 per Ton.

PURE DISSOLVED ANIMAL BONE.

Made from strictly pure Animal Bone.

Price, - - $\$ 30.00$ per Ton.

AMMONIATED BONE PHOSPHATE.

A high grade Ammoniated goods; used extensively for wheat and grass.

Price, - - \$28.00 per Ton.

\section{BUTCHER'S BONE PHOSPHATE.}

Made largely from Bone, Meat and Blood. Used on both Spring and Fall crops. One of the cheapest articles on the market for the money, as it is rich in Ammonia, Potash and Phosphoric Acid.

Price, - - \$25.00 per Ton.

\section{AMMOINATED SOLUBLE BONE.}

Prepared especially for farmers who want an Ammoniated goods but who do not desire much Ammonia.

$$
\text { Price, - - \$24.00 per Ton. }
$$

\section{SOLUBLE BONE PHOSPHATE.}

In fine mechanical condition; a good Fertilizer for the money.

Price, - - \$21.00 per 'Ton.

HIGH GRADE ACID PHOSPHATE, or Dissolved S. C. Rock.

Finely ground, dissolved and in good condition. 


\section{FULL LINE OF FARM AND GARDEN HARDWARE.}

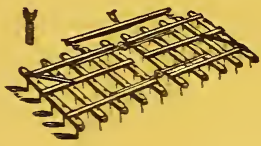

Garden Harrows.

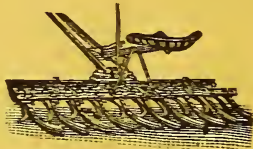

Acme Harrow,

$\$ 20.00$ to $\$ 25.00$.

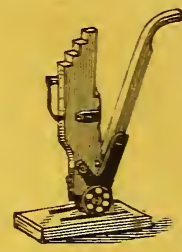

Wagon Jacks.

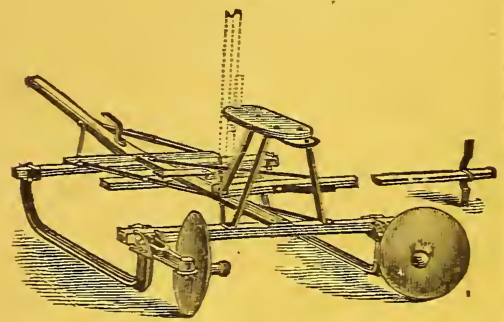

Darnell's Pat. Furrower S Marker.

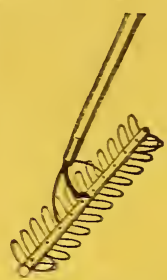

Daris' Lawn Rake. Price. 75 ets.

$\$ 1.50$ to $\$ 4.00$.

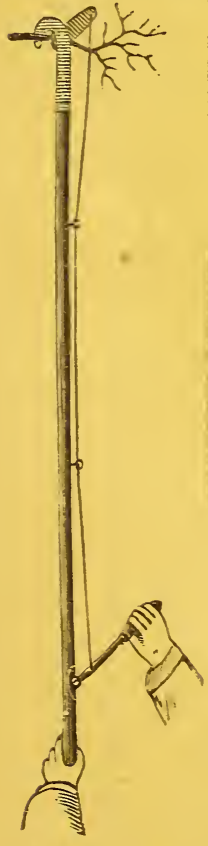

Tree Pruner.

LEWIS COMBINATION FORCE PLMP.

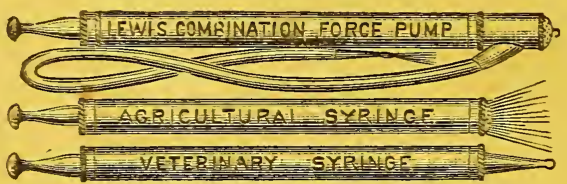

It makes 3 complete polished brass machines, (see cut.) To introduce we will send a sample pump. express paid. for \$5.00 and will also give a raluable illustrated book, just published, containing the latest and best receints for insects of all kinds, to each purchaser of a pump. Receipt alone are $\pi$ orth \$5.00). Pump will throw water 50 to $60 \mathrm{ft}$. Indispensable for spraying fruit trees. lioods guaranteed as represented. Send for illust'd catalogue, price list, $\&$ c.

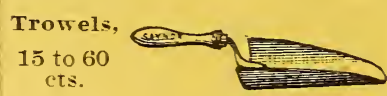

cts.

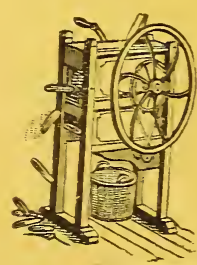

Little Giant Corn Shellers

Double Spout Shellers, \$16.

Double Spout shellers with shaker, \$20.

Single Spout, With Fan, \$1i. Without, \$9.

Oat and Barley Forks.

Grass Edging Knives.

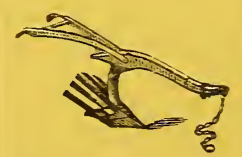

Potato Plow.

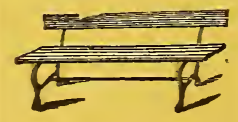

Settees.

FOR LAWNS ANO HALLS.

$41 / 2$ feet, - $\$ 4.30$ $51 / 2$ feet, - 4.80

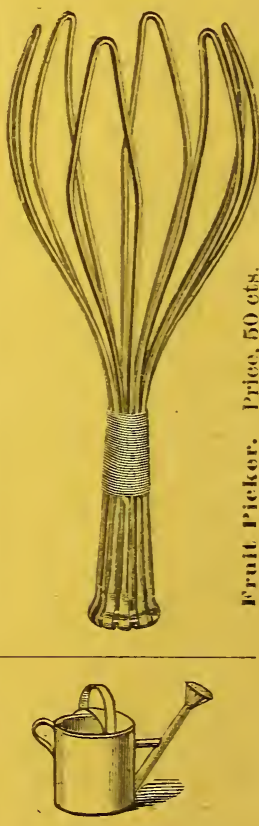

Watering Pots. 


\section{FULL LINE OF FARM AND GARDEN HARDWARE.}

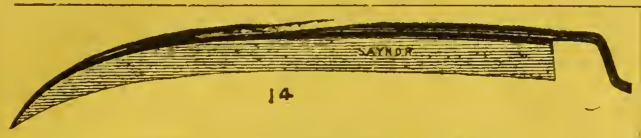

Scythes. American, 65 and 75 cts.

English T. Waldron, \$1.25. Snathe or Handle, 35, 50 and $75 \mathrm{cts}$. Scythe stones, 5, 10 and $20 \mathrm{cts}$.

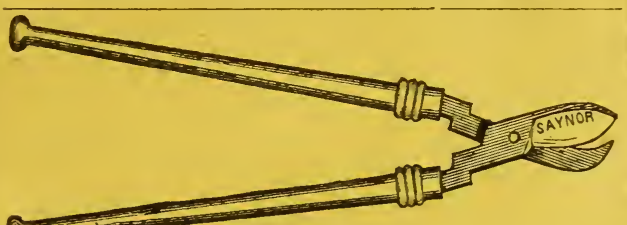

Shears. Medium, \$2.50; large, \$3.50.

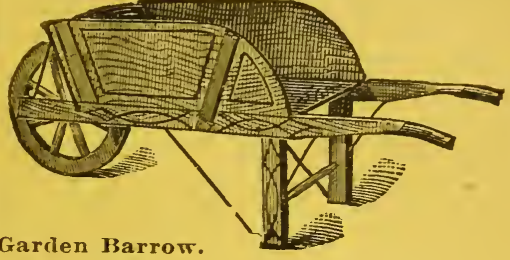

Made of best timber; nicely finished.

No. 1, Boy's size,

$\$ 3.50$

No. 2, "

To. 3, “ "

No. 4, Man's " $\quad$ - $\quad$ - $\quad$ - $\quad$ - $\quad$ - 4.50

No. 5, " " $\quad$ - $\quad$ - $\quad$ - $\quad 5.50$

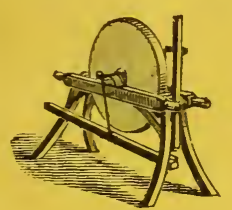

Grind Stones.

(MOTNTED.)

No. $1, \$ 4.50$; พo. 2 ,

\$4.00; Y. 3 , \$3.50.

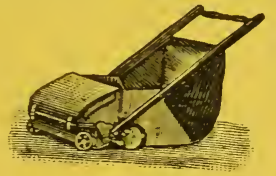

Lawn Sweeper.

Revolving brush; sweeps all refuse back into box.

Hand Machine, - \$16.00

Horse "“ - $\$ 6.00$

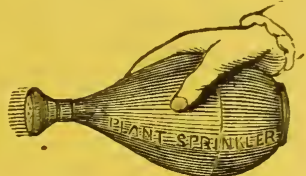

Rubber sprinkler.

For sprinkling cut flowers, seedlings, plants and clothes

Price, \$1.00; by mail, \$1.15

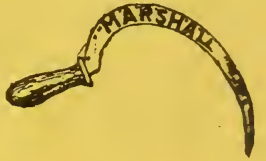

Grass Hooks.

American, 40 cts.

English 50 "

German, 50 “
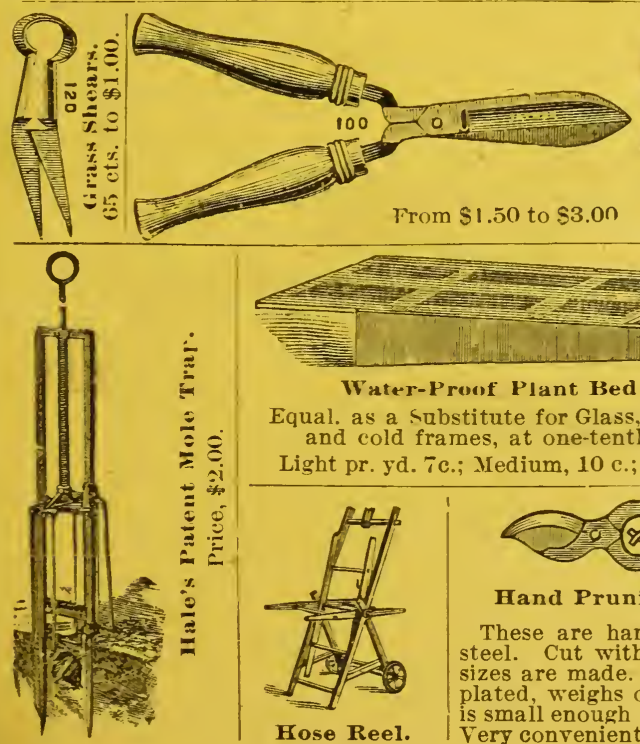

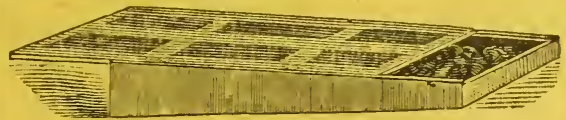

Water-Proof Plant Bed cloth.

Equal. as a Substitute for Glass, on Hot Beds and cold frames, at one-tenth the cost.

Light pr. yd. Tc.; Medium, 10 c.; Heary, 14 c.

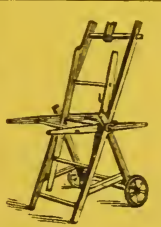

Hose Reel.

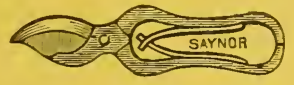

Hand Pruning Shears.

These are hand-forged, solid steel. Cut with ease. Sereral sizes are made. One is nickelplated, weighs only 3 ozs., and is small enough for rest pocket. Very convenient for ladies' use.
Excelsior Portable Hand Force Pump.

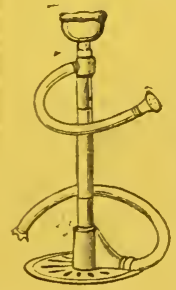

To place in bucket crtub The ligntest and neatest thing of the kind we hare seen; throws water 40 feet Change from stream to spray instan? tily.

Price, complete, \$4.50.

Large Assortment.

Lowest Prices. 


\section{Philadelphia Hand Horse Lawn Mowers}

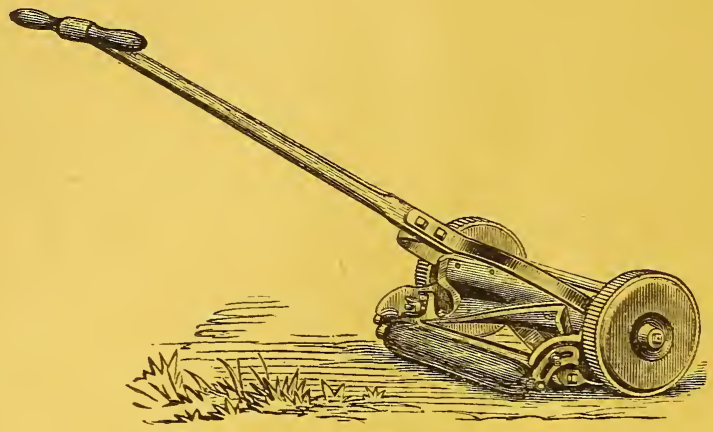

Philadelphia Hand Mower.

Simple in construction; durable and light running-therefore cheap. Full stock of machines and repairs always on hand. This is a favorite and always pleases the buyer.

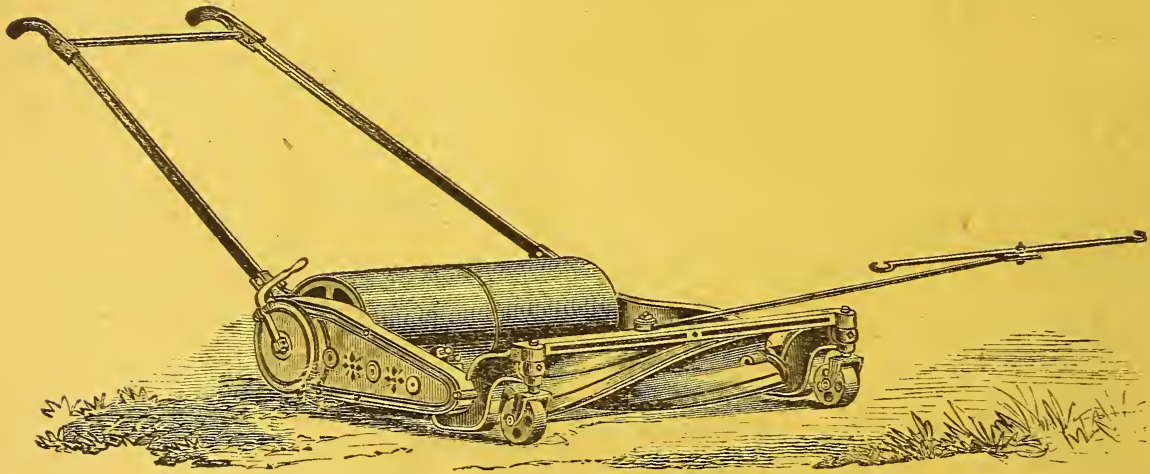

Philadelphia Horse Mower.

In use at Druid Hill Park, at many other Parks and Squares and on a large number of lawns in this vicinity. A first-class machine in every respect,-always on hand at lowest prices.

We make a Specialty of Repairing Lawn Mowers, for which purpose we employ efficient mechanics, and in this way become thoroughly acquainted with the construction of all machines on the market.

When you buy a Lawn Mower, be sure to select one which has merit, and for which you can get repairs. The Philadelphia is just such a machine. Write for Special Cir. cular and Prices. 


\section{Continental Hiğh Wheel Mower.}

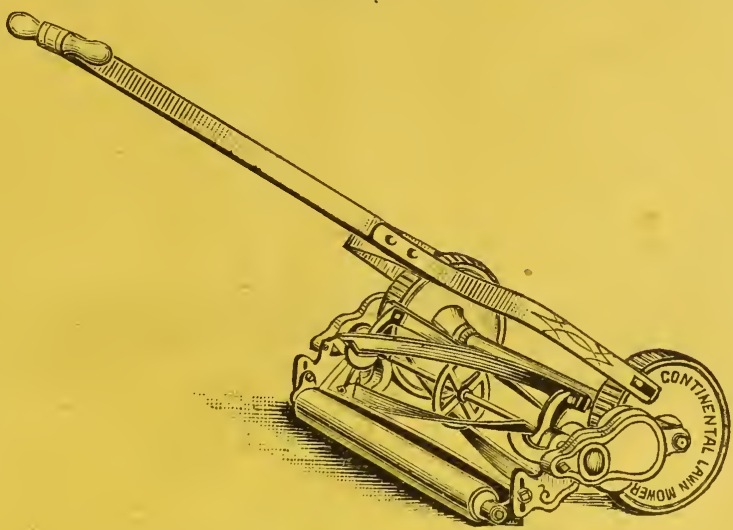

Continental High Wheel Mower.

A distinct type of machine in popular favor.

Owing to the demand for a High Wheel Mower for uneven lawns we have secured what we consider the best machine of the kind made. Every customer more than satisfied with the Continental.

In use at Patterson Park, and on the lawns of Messrs. Robert Garrett, William H. Whitridge, R. B. Smith, German H. Hunt, Edw. A. Griffith, at Church Home, the Woman's College of Baltimore City and very many others.

Splendidly built. A full stock of machines and repairs always on hand. Write for Special Circular and Prices.

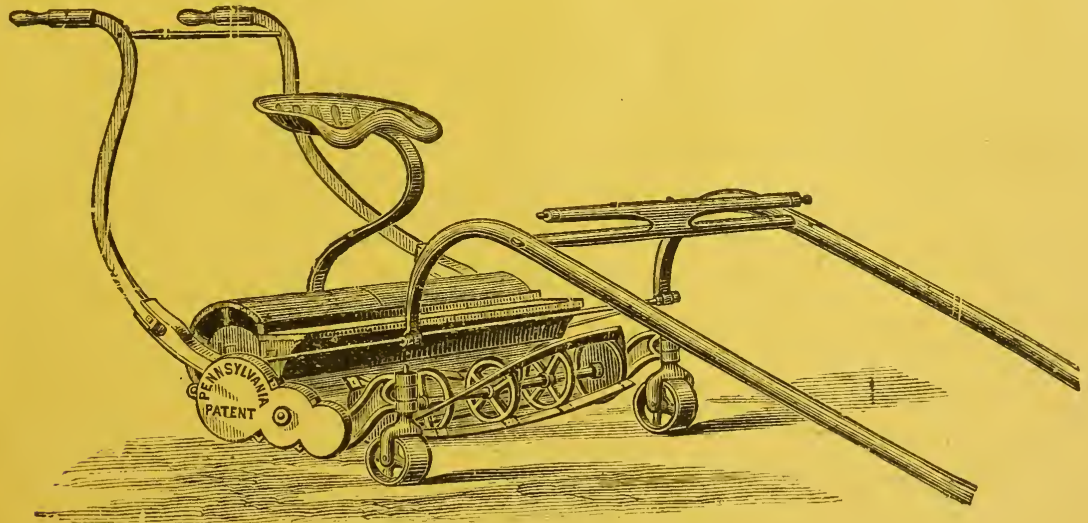

\section{Pennsylvania Horse Mower.}

The Pennsylvania is a complete Mower, well-made, easily repaired, and one which can be recommended to purchasers. One of the best. Write for Circular and Prices. 


\section{THE No. 4O,}

\section{Full Chilled, Sloping Landside, Both Right and Left Hand.}

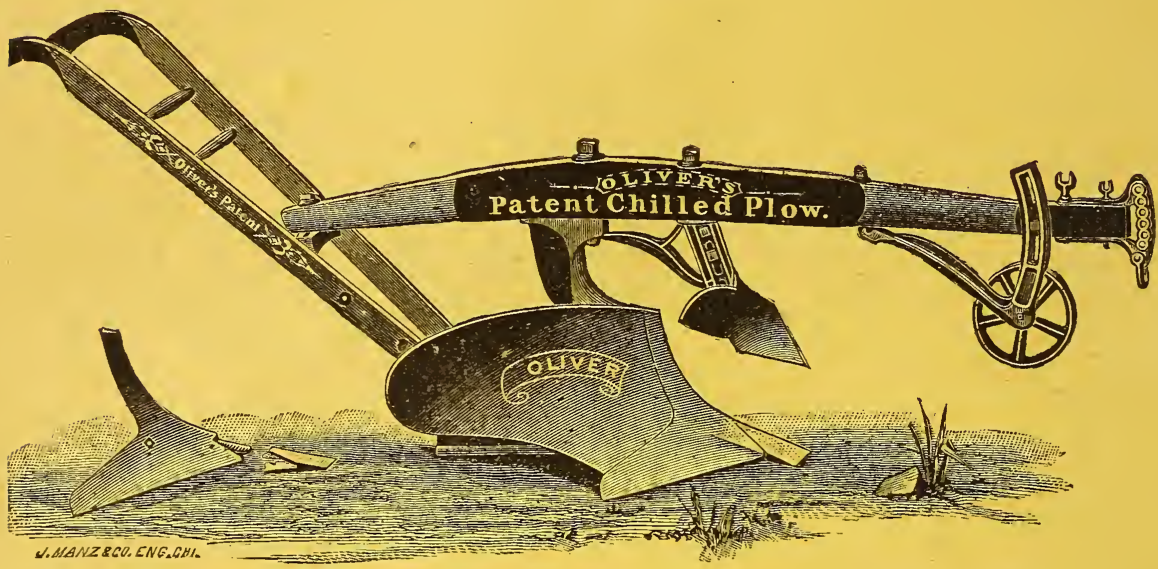

\section{Here we present a Cut of the World Famous No. 40 Series, embrac- ing the Numbers 10-0, 13, 19, 20, E and 40 Plows.}

These patterns are better known, have reached a larger sale, have proved more popular, and given better satisfaction than any plows on the face of the globe. They are durable, easily handled, easy running, perfect in their work, economical in repairs, and have done more to advance the science of farming than any other agency ever employed. They are made only of Oliver's celebrated chilled metal, are made both right and left hand, and every plow has the name "Oliver" on beam, handles, and wearing parts. They are the best general purpose plows in the world, have had the longest run, and their reputation has been maintained from first to last. They are fitted with the new share and reversible slip point shown on the next page, and also with the regular share so well known and so often counterfeited. They will continue to hold their places in public favor in spite of all the opposition brought against them ; and the farmer who wants the best plow made will make no mistake in buying the "Oliver." In buying shares and other extra wearing parts, be sure that the name "Oliver" is cast on them. All others are imitations and not to be depended on in any respect. 


\section{OLIVER'S PATENT SLIP NOSE SHARE.}

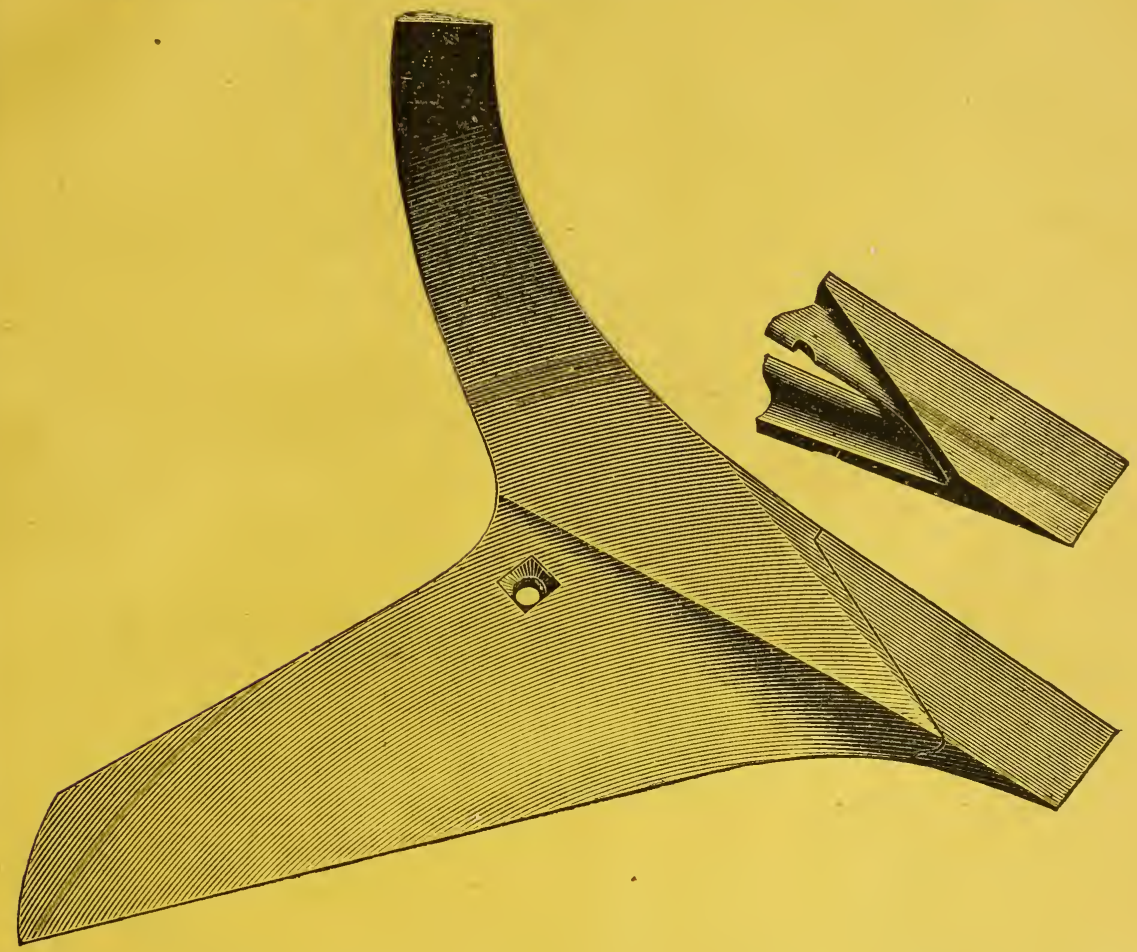

Special attention is directed to the new Share in the cut above shown. It is called "Oliver's Patent Slip Nose Share," and represents the grandest improvement in the way of a saving device ever offered to the tillers of the soil. It is a well known fact that the Nose of any share wears off more rapidly than any other portions, and is more liable to breakage in rough or stony ground. In the new Slip Nose Share these annoyances are overcome, for the point can be removed, reversed or replaced readily, and a new share is practically the result. Both the Share and the Slip Point are made heavy where they join, and being fastened with a nail, key or even piece of wood, the arrangement is so simple that any one can easily make the changes.

This new Share is adapted to use on all the No. 40 series, which embraces the IO-O, I3, I9, 20, E and 40 plows. In fact, all Oliver chilled plows, outside the "Combination" series, will be so fitted, and will have this advantage when Cast Shares are used.

Users of our plows will appreciate the fact that this Share and Point can be used on their old plows, which have done such good service, and they will not have to buy a new plow to get their benefits. We offer this device as a practical, sensible and economical invention, and one that will give thorough satisfaction upon trial and use. 


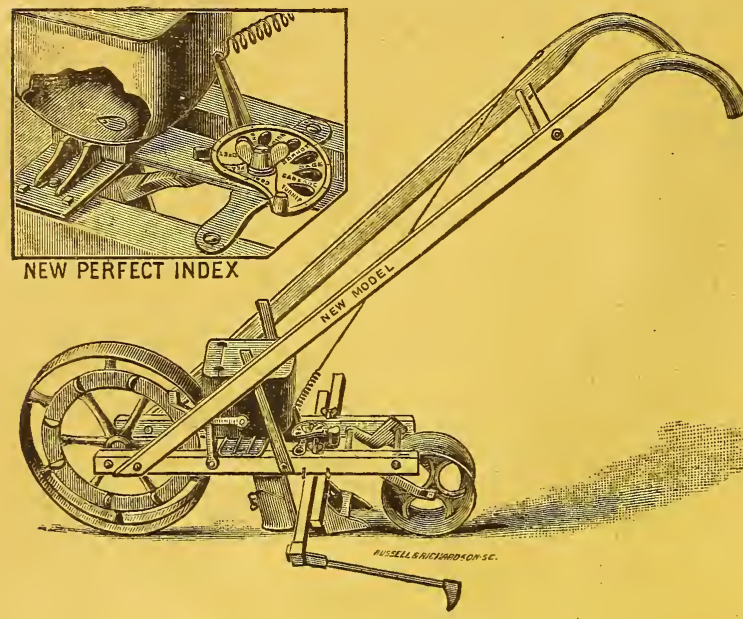

\section{THE- \\ New Mođ́di Serd Drill \\ GUARANTEED TO BE \\ The Most Perfect Drill}

IN AMERICA.

Thoroughly tested and fully endorsed by all the Leading Seedsmen of the country.

Each year emphasises the fact that it is still at the head of the line.

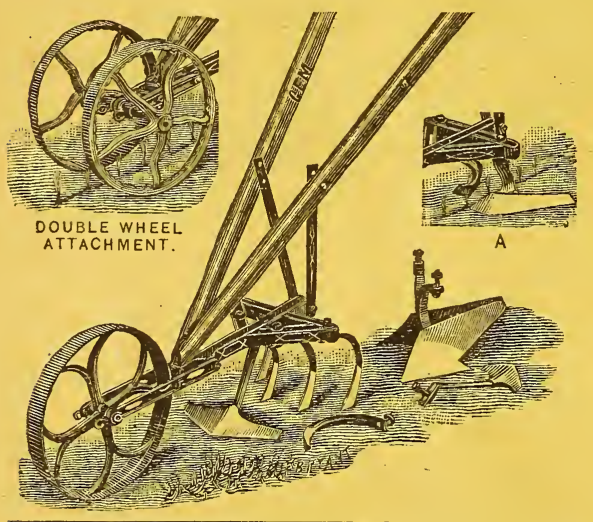

\section{The BEDI WHEEl HOE.}

An Old Tool, but Nothing Beats it Yet.
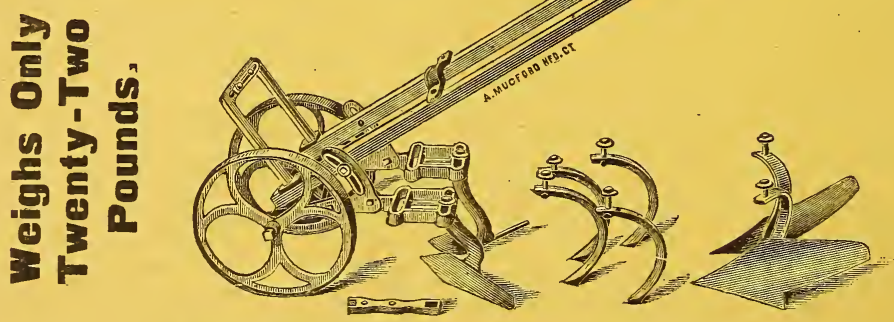

The "JEWEL" Double Wheel Hoe and Gultivator Combined.

All malleable iron and steel, with the exception of wheels and handles. Adjustable in every way. 


\section{THE "IRON AGE" HORSE HOE.}

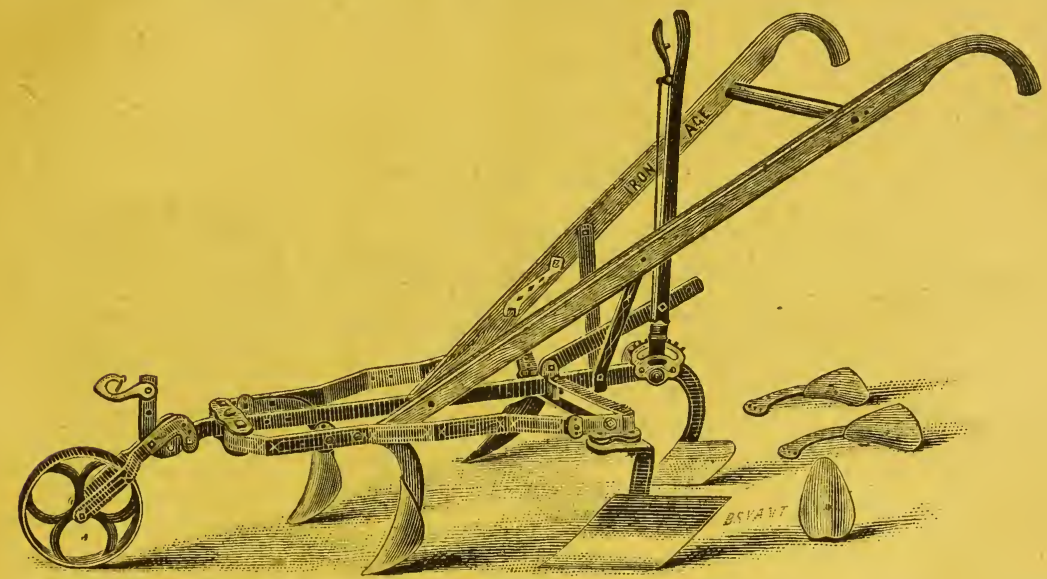

SHOWN WITH WHEEL AND CULTIVATOR COMBINATION, ALSO WITH LEVER ADJUSTER.

One of the most satisfactory implements, for a reasonable price, ever made on this continent. Probably no tool has been so widely imitated as the "IRON AGE" Cultivator, the original of this style of implement, and we are quite sure no other tool has kept so far ahead of its imitators. All Steel frames. New shape side bars, giving facility to use tool either with five or seven teeth-a grand, good thing. Sold with or without Lever Adjuster.

\section{"Iron Age" Combined Harrow and Cultivator.}

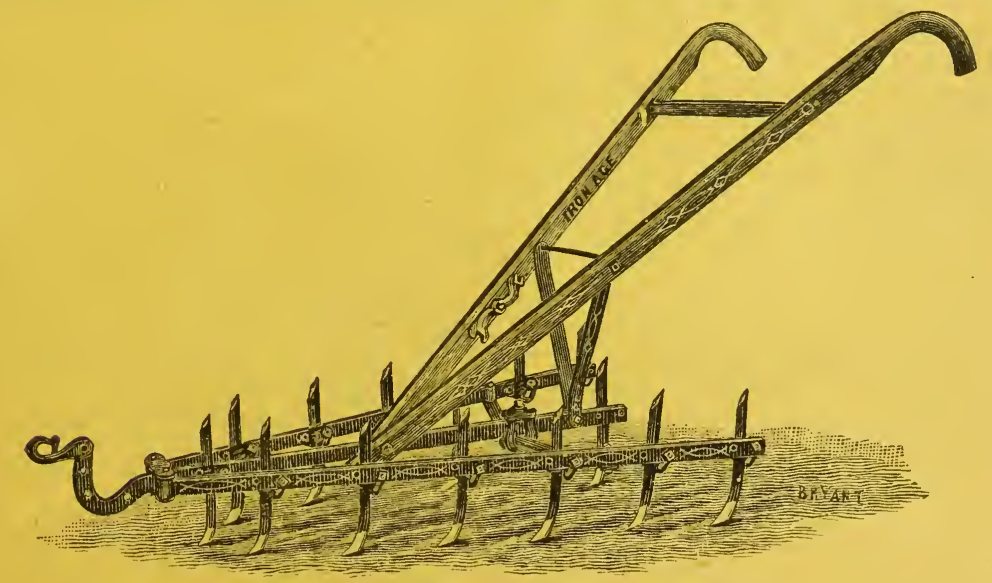

STEEL TEETH, DIAMOND SHAPE.

A comparatively new implement, but one every way worthy of purchase by all wide-awake farmers. They cannot afford to do without it. Four positions of teeth, doing good work in all crops. 


\section{$\rightarrow$ BATEMAN'S:}

COMBINATION OF

\section{Barrel Truck, Hand Cart, Sprinkler and Barrel Force Pump.}

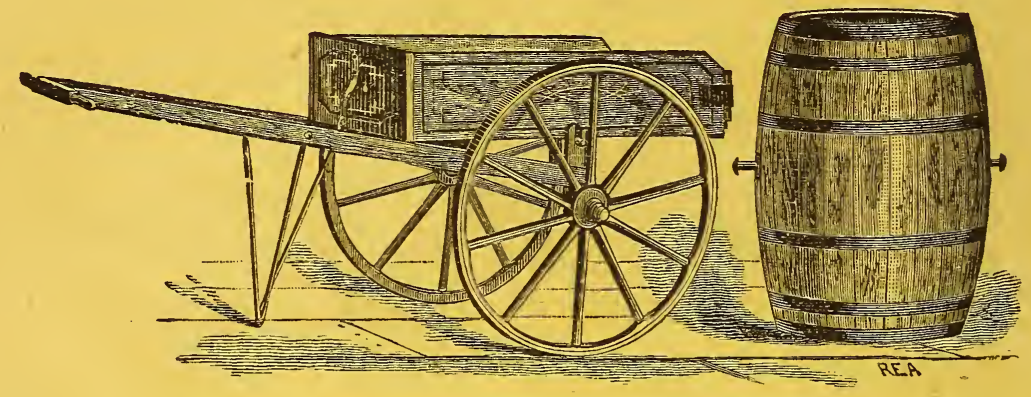

When we consider the almost innumerable uses to which the Combined Truck and Hand-cart can be applied, its "handiness" and the immense amount of time and hard labor saved by its use, it is not a matter of surprise that it is steadily growing into favor. It is one of those articles that causes the user to wonder how he ever did without it, as it really becomes indispensable when once used.

The Barrel is raised from the ground, carried to the place desired and instantly detached, all without handling. The weight being balanced over the axle, no lifting or down pressure is needed in transportation.

Other barrels for various purposes can be used as needed, extra trunnions being furnished, if desired, which can be readily attached to any oil or spirit barrel, thus increasing indefinitely the value of the Truck.

We have wheels of $I 1 / 2,21 / 2$ and 4 inches tread, but always send Truck with Wheels I $1 / 2$ inches, unless otherwise specified.

We also supply a Box, with trunnions and spring catch, making a very superior dumping Hand-cart. No castings to break; all irons of the best wrought. Very stiff, compact, handsome and low in price. Furnished with or without Barrel or Box, as ordered. A first-class force pump, entirely of brass, furnished as an attachment. Just the thing for washing windows and carriages and for spraying trees.

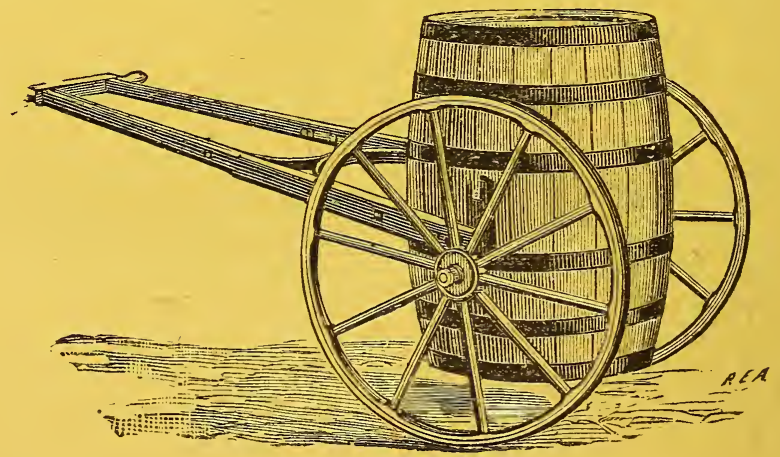




\section{BEST SMOOTHING HARROW MADE.}

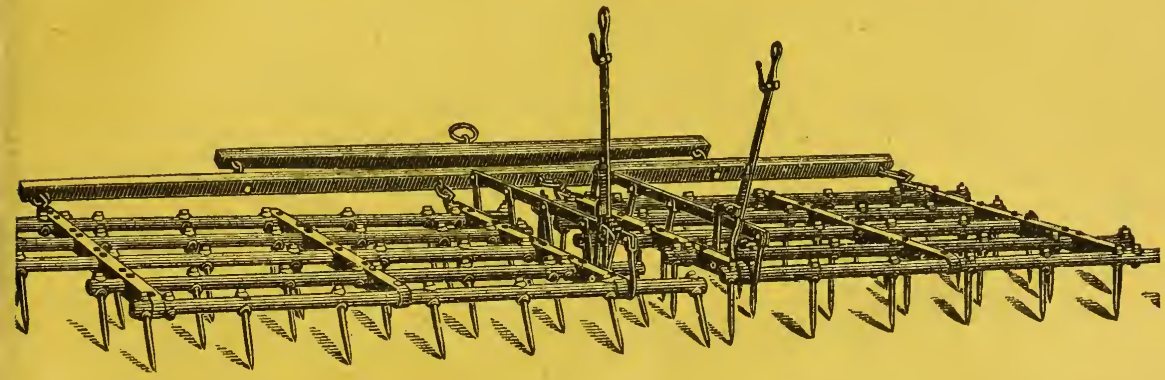

Owing to the greatly increased demand for smoothing harrows, we have contracted for the best line of goods of the kind on the market. Every Evans Harrow we have ever sold has given perfect satisfaction.

\section{EVANS ADJUSTABLE STEEL FRAME HARROW.}

The above cut represents our New Lever Harrow. It can be used as a stralght tooth pulverizing Harrow, or a slanting tooth smoothing Harrow. By means of the lever the teeth can be set straight or to any desired slant. The beams are made of iron tubes and the teeth pass through the same and are threaded and held firmly in place by a tap. If stalks or trash accumulate on the teeth, when used as a straight tooth Harrow, the teeth can be changed in a moment by means of a lever, to a slanting position for cleaning off the trash. As a smoothing Harrow it never clogs, all rubbish being cut in two, or passing down and off the ends of the teeth and is completely buried; and for cultivating young corn in its early stage, it is unequaled. It thoroughly pulverizes the soil and destroys the weeds, while the young corn remains uninjured. Specially adapted to cultivating wheat in the spring. Price \$20.00.

\section{THE EVANS TRIPLE HARROW.}

\section{SIMPLE, PRACTICAL, COMPLETE.}

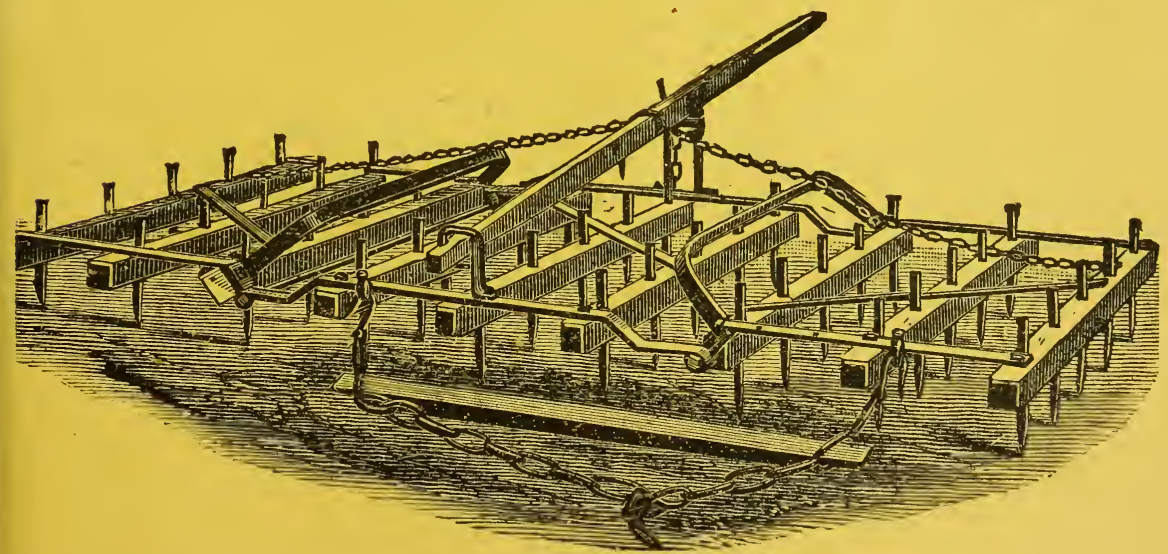

Has Runners ready for the road without unhitching the team. Convenient to move from place to place about the farm. Any boy can handle it. Saves labor and time.

DESCRIPTION.-It has a Lever Attuchment, by aid of which each section can be raised clear of the ground, and cleaned of stalks or trash, or passed over stones or stumps without stopping the team, and is so easily handled a boy can operate it. Price $\$ 17.00$, 


\section{CLARK'S CUTAWAY HARROW.}

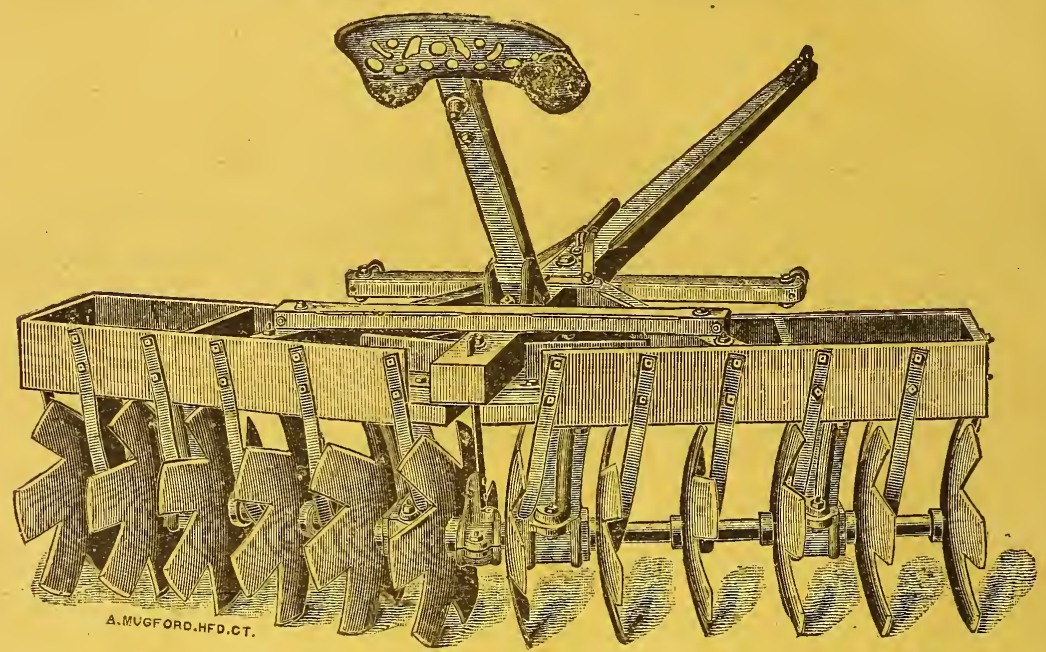

\section{One of the Greatest Inventions of the Age. A Trimmph of Mechanical Genius.}

The most complete disk harrow made; will run 25 per cent. lighter than the solid disk and do very much better work; will not ridge the ground; impossible to clog; cuts the weeds and trash at the same time mixing them with the soil. Besides these advantages, the Cutaway is provided with the new mechanical movement of ball and socket joint, where the wings of the harrow connect at an angle under the end of the pole. This little part is by itself one of the triumphs of mechanical genius. A connection of this kind allows the axles to revolve at distinct angles, and besides cutting and slicing, the implement tears and twists the sod and mixes the soil, putting that which is on the top under, and bringing up the lower earth so far as it reaches. This can be regulated by weighting the drag. With all this motion, there is but little of the side displacement of soil that is so objectionable and damaging a feature of old disk harrows. Considering these movements, one cannot fail to reason what a perfect seeder it must prove. I2 Disk, I6 inches, Price $\$ 30.00$.

Send for List of Farmers and Gardeners who use and recommend the Cutaway. Among very many others we call your attention to the following:

Baltimore Manual Labor School Farm, Aug. 23, i889.

Mess. Griffith, Turner \& Co.

Gentlemen :- We are delighted with the Clark's Cutaway Harrow. It is decidedly the best pulverizer we have ever seen. We can do more pulverizing with it, especially in heavy clayed soil, in one day than we can do in two with any other harrows that we have ever tried or seen work. It does not bring up anything that has been plowed under, but cuts up and mixes manure, etc., with the soil.

$$
\text { Respectfully, }
$$

E. Stabler.

Mess. Griffith, Turner \& Co.

The Cutaway Harrow gotten of you has given perfect satisfaction, and consider it the implement for much work which cannot be performed satisfactorily with any other form of surface pulverizer I have seen. In short, it will do well what any other harrow will do and much that no other will.

Very Respectfully, J. H. Goodridge, Mgr. for J. H. Rieman. 


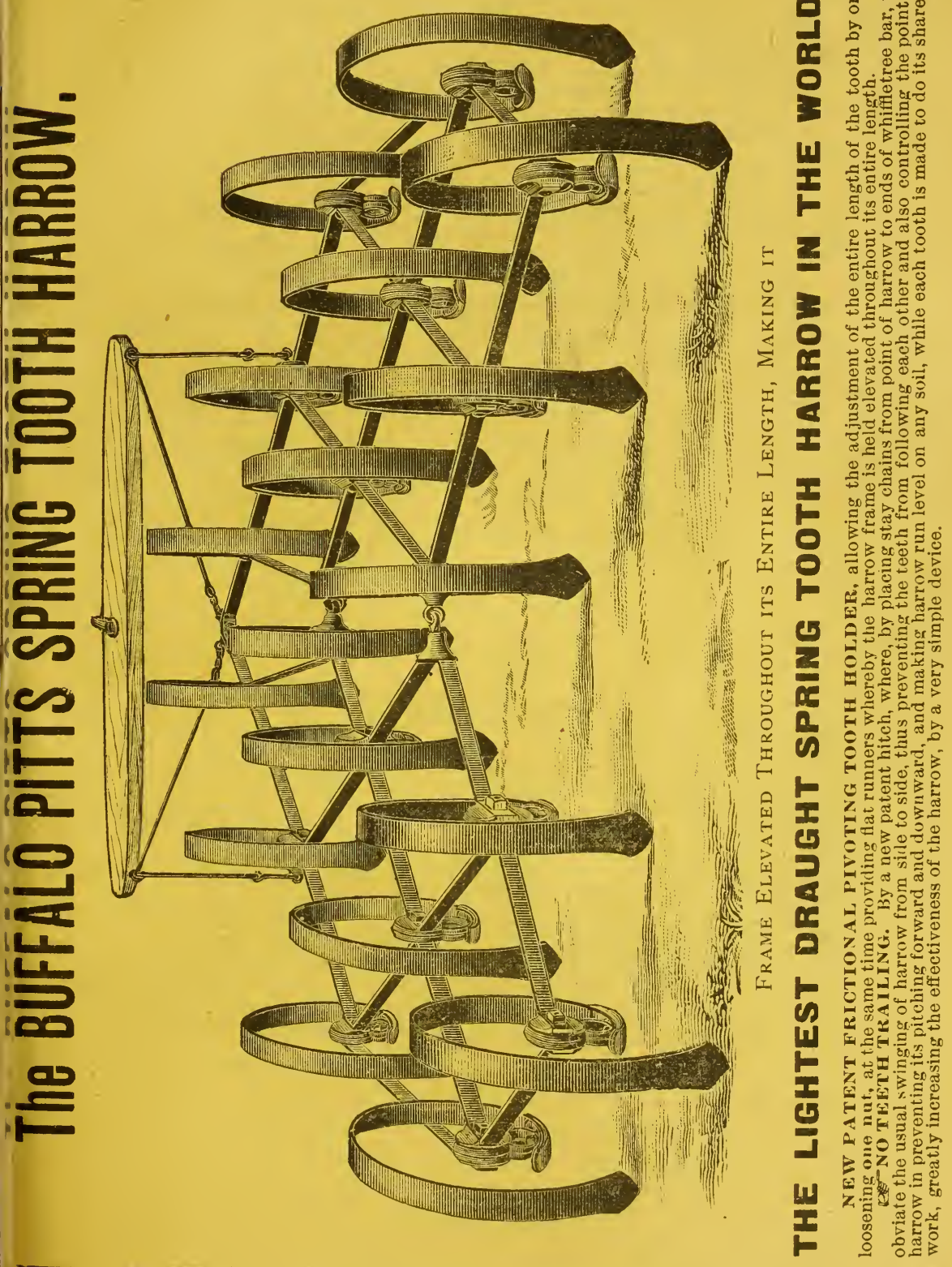




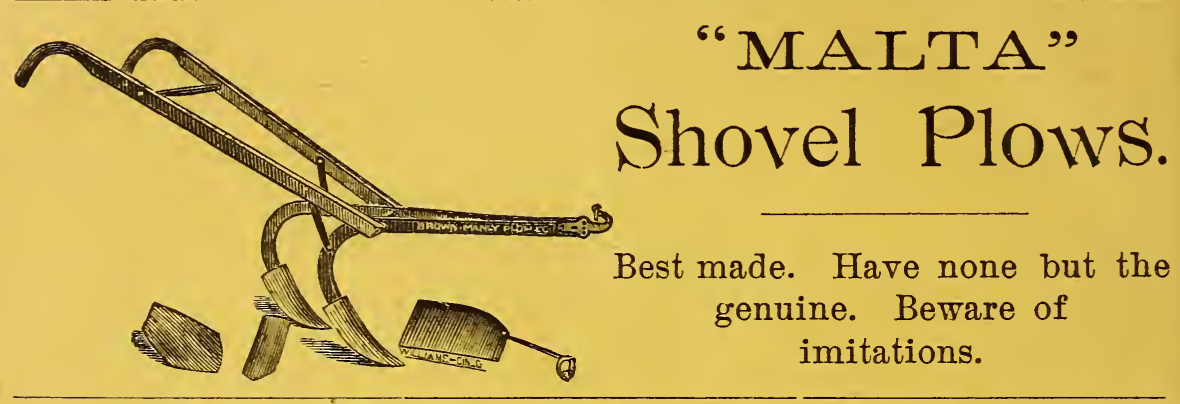

\section{Maita Malking and Riding Cultivators.}

Its numerous adjustments combined with neatness, strength and durability, make it the favorite. One of the most useful implements in use. The Malta has been sold in this section for years, and has proven itself worthy of the reputation it enjoys throughout the country. Malta Rider, \$30.00. Malta Walker, \$25.00.

REFERENCES :---Wm. D. Griffith, Shawan, Balto. Co., Md. E. A. Talbott, Ellicott City, Howard Co., Md• Joshua W. Dorsey, Ellicott City, Howard Co., Md. Devries \& Miller, Arlington, Balto. Co., Md. And many others.

\section{Lawn and Field Rollers.}

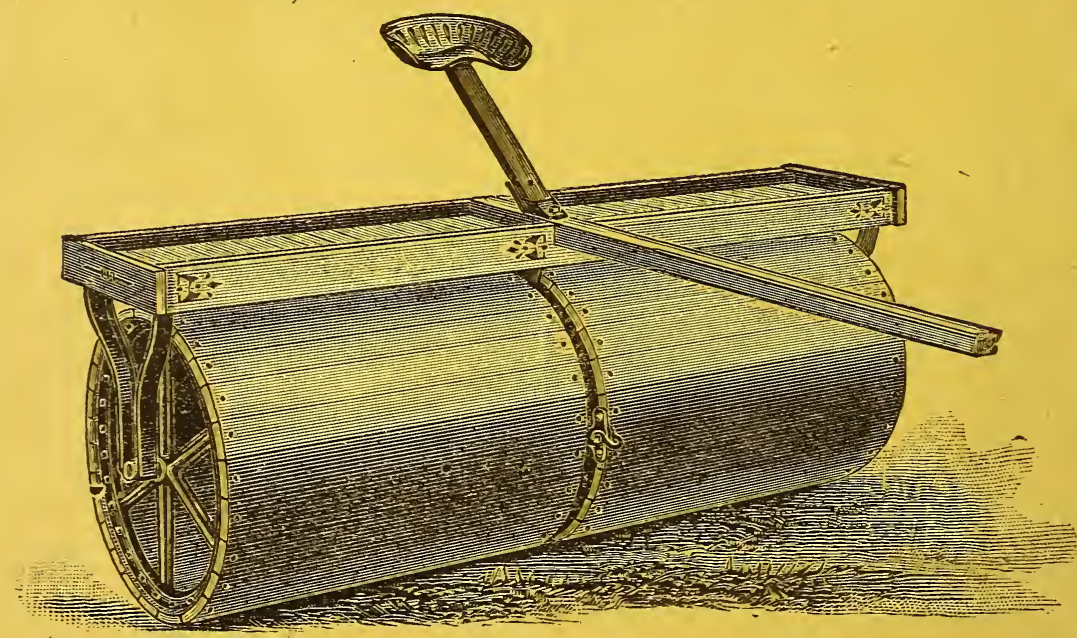

\section{Lawn Sizes and Prices:}

No. o, Io inch diameter, 2 sections, $61 / 2$ inch face, I30 lbs., - - - - - $\quad \$ 7.00$

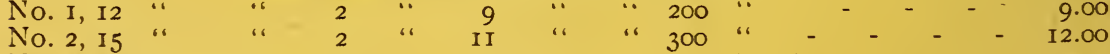

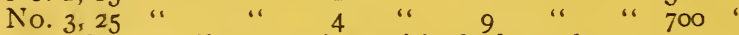

36.00

horse rolier complete with shafts and seat.

Field Sizes and Prices:

Wood Field Rollers, 28 inches diameter, - _ _ _ _ _ - $\$ 30.00$

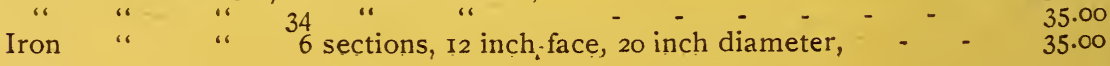




\section{The NEW EVANS GORN DRILL}

With and without Fertilizer Attachment. Also arranged for Planting Peas.

Plain Drill, - - - $\$ 16.00$

With Fertilizer Attachment, $\$ 20.00$
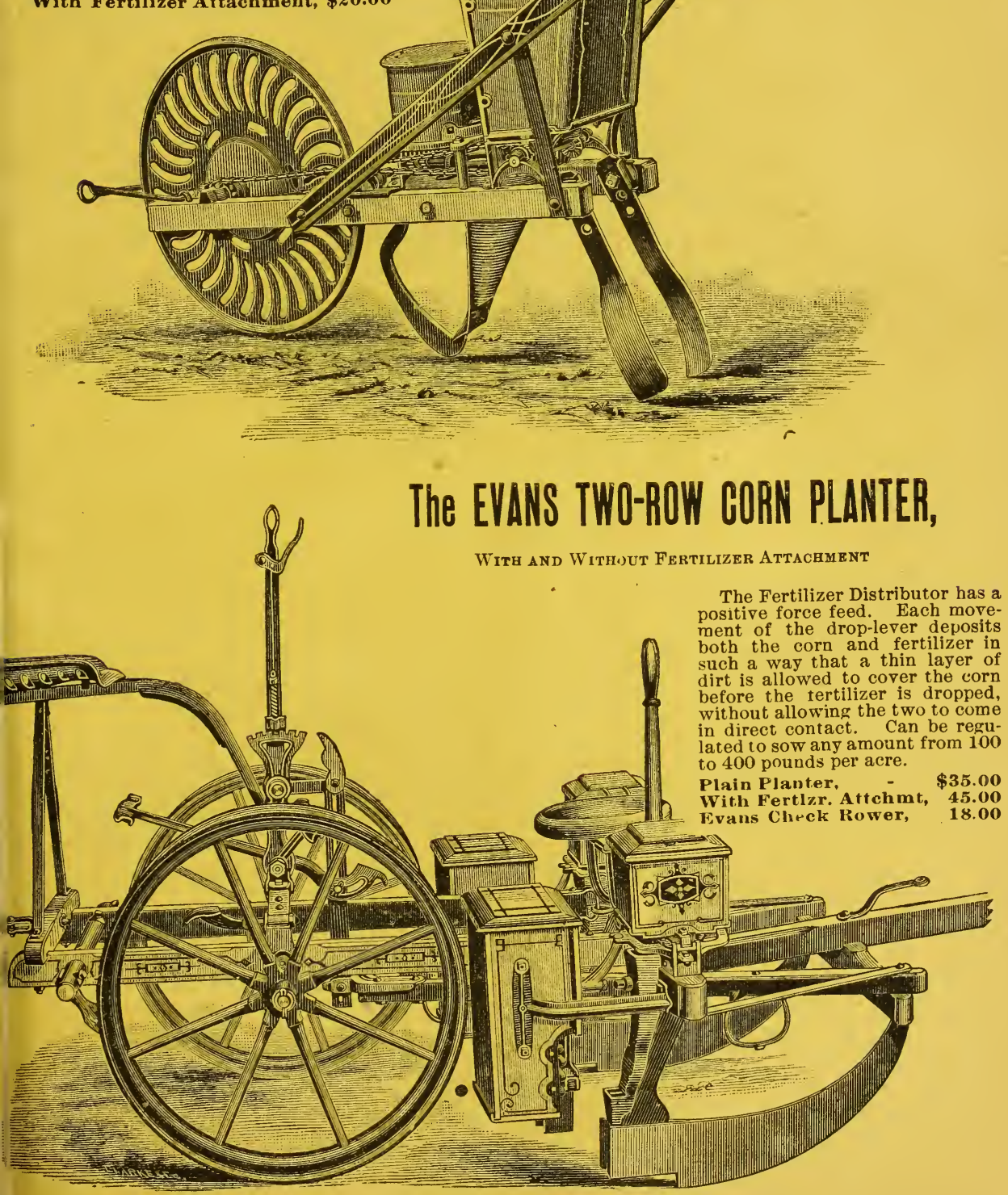


\section{$\rightarrow$ PHHOON'S PATENT BROADGEST SEED SOWER $\%$}

$\longleftrightarrow$ FOR SOWING

Wheat, Oats, Hemp, Barley, Rye, Buckwheat, Grass, Seed, Rice, \&c.

SOWS FROM

4 to 8

ACRES PER

HOUR,

At an ordinary walking gait, throwing $W$ heat about $\mathbf{4 0}$ feet wide.

SPECIAL GATE for GRASS SEED.

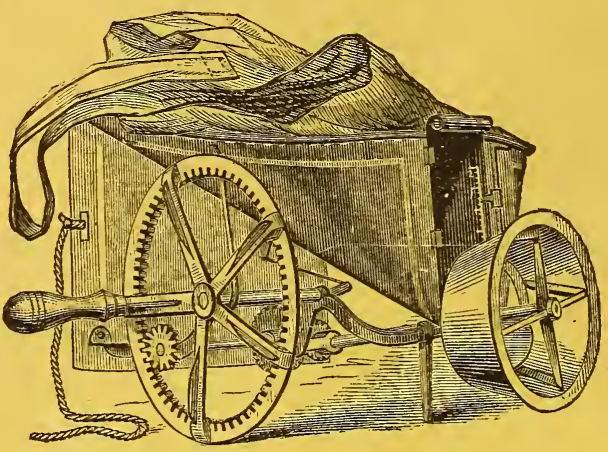

WARRANTED

TO GIVE

PERFECT

SATISFACTION,

And save their cost in less time than any other implement yet offered.

STRONGLY BUILT : LAST FOR YEARS :

The acknowledged superiority of these machines over all others has already placed them in the front rank of labor saving implements. A saving of four-

fifths of the Labor and one-third of the Seed is effected by

their use, and a person entirely unused to sow-

ing by hand can use this machine

with perfect success.

The Breadth of the Cast will be according to the Weight of the Seed.

The Heavier the Seed the greater the Distance to which it is thrown. The passages ordinarily should be as follows:

Wheat \& Rye, from 30 to $36 \mathrm{ft}$.

Barley,

Hemp,
66 27 "63 66

66 27 " 30 "6
Oats, - - from 21 to $25 \mathrm{ft}$. Clover, Millet \& Hung. Seed, " 20 " $\mathbf{2 4}$ "6 Timothy, - " 15 " 18 "

\section{ABOUT SOWING IN THE WIND.}

Anyone familiar with the use of the machine, can sow satisfactorily in a much stronger wind than will admit of sowing well by hand; but as the ordinary work of a day can easily be done with the Sower in two or three hours, that time may be chosen early in the morning or late in the afternoon-when it is usually calm, or nearly so.

\section{PRICE, \$4.0O.}




\title{
Thompson's Glover and Girass S'eeder.
}

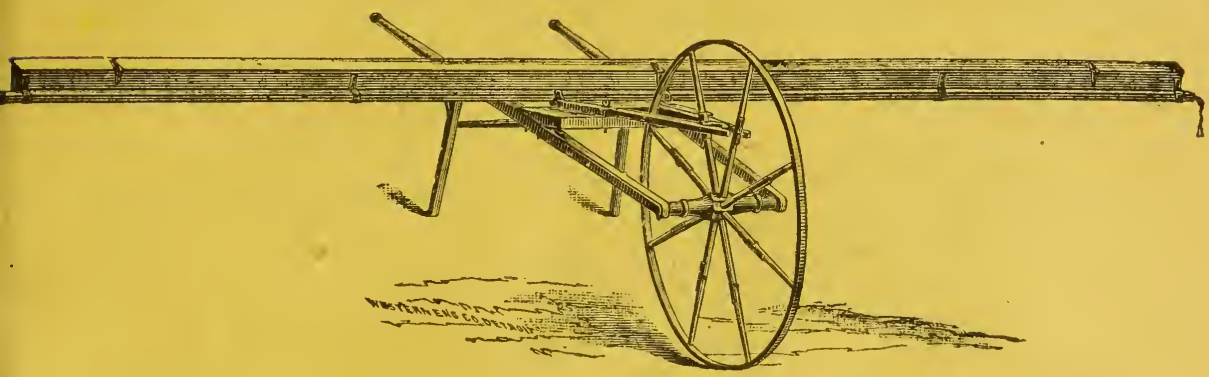

One of the best articles illustrated in this Catalogue. Sows 12 or 14 feet wide, any amount desired per acre. 'Can be used in wet, dry or windy weather. Will sow $20^{\circ}$ to 25 acres per day, and does its work accurately. Read what Messrs. James Oliver and J. I. Case, the noted manufacturers, say about it:

o. E. THOMPSON,

Office of Oliver Chilled Plow Works, South Bend, INd., Dec. 11, 1886.

Dear Sir:-The Seeder purchased of you has had my personal examination, and I am pleased to say that I regard it as being most complete in every respect. The reputation it enjoys is fully merited; and were I to need another I would not hesitate to buy yours. In fact I would hare nothing else. Wishing you all possibie success in its manufacture, I remain,

Yours truly,

JAMES OLIVER.

\section{J. I. Case Threshing Machink Co., Racine, Wrs., Aug. 19, 1887.}

O. E. THOMPSON,

Dear Sir:-The Thompson Clover and Grass Seed sower you sold me works to my entire satisfaction. No man farming 40 acres can afford to be without one. Mine is loaned half tha time to my neighbors. I may have to get another so as to keep one for my own use.

Yours, etc.,

J. I. CASE.

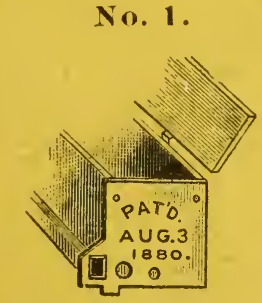

CLOVER.

\section{END VIEW. No. 2 and 3.}

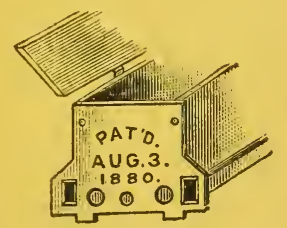

RED TOP.

CLOVER.

PRICE LIS'T.

\begin{abstract}
No. 1 Complete Clover and Grass Seeder, - the most popular styie, - - - - \$10.00
No. 2 “ Seeder with Double Hopper for Red Top, Orchard Grass, etc., _ _ 12..0

No. 3 " " " " "Flax and large quantities of Millet, 12.50
\end{abstract}




\section{TEIE FAFMIEIR'S FRIEND.}

\section{The Staver Buckeuge Feed mill and Power Combined.}

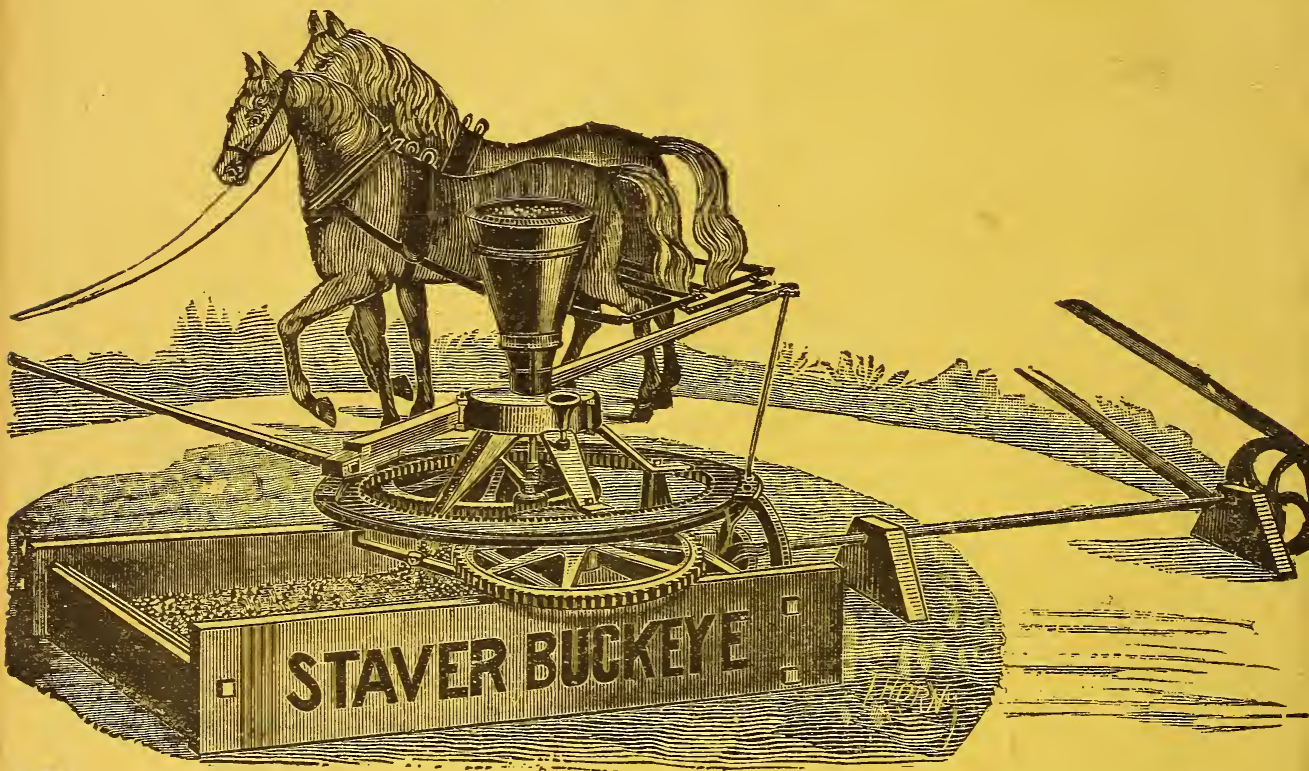

Fan For grinding corn and cob or shelled grain. Can also be used as a separate two horse power for running other machinery. The combination of a Feed Mill and a Horse Power in one Machine makes a great reduction in the cost, and furnishes a light running machine which meets with general favor. There are nearly fifteen thousand of these combined mills now in use, and the demand grows every year, proving that it is what the farmer needs.

The Staver Buckeye is a rapid grinder yet light running, and just right for two horses.

The Sweep is so constructed as to utilize End Pressure and apply it to turning the Master Wheel, making a saving of 20 per cent. in draft. It can be attached quickly, without using wrench or bolts.

Among list of farmers and dealers who use and handle these mills, we refer you to:

White Hall, Balto. Co., Md.-This is to certify that we ground at the rate of twenty $(20)$ bushels an hour corn and oats, mixed half and half on a Staver Buckeye Mill with two horses weighing nine hundred pounds each.

$$
\text { Signed, THOMAS LYTLE, }
$$

Geo. B. Graham, Baltimore, Md.

Samuel J. Messersmith, Baltimore, Md.

J. March McComas, White Hall, Balto. Co., Md.

J. M. Anderson, Phœenix, Balto. Co., Md.

A. A. Miller, Upper Falls, Balto. Co., Md.

Mount Hope Retreat, Balto. Co., Md.

Dr. Wm. Lee Stevensons, Balto. Co., Md.

Chas. Holmes, Manor, Balto. Co., Md

Rev. E. E. Shipley, Cooksville, Howard Co., Md.
Geo. F. Gallion, Marriattsville, Howard Co.. Md. Thos. H. sandford, Fllicott ' ity, How'd Co., Md. P. L. Hargett \& Co., Frederick, Md.

I. T. Fulks \& Co.,Gaithersburg, Montgm'y Co., Md.

E. Young, St. James College, P. O., Wash. Co., Md.

S. M. Anderson, New Freedom, York Co., Pa.

J. K. Barnitz, Hanover. York Co.. Pa.

J. H. Fortenbaugh, Mechanicsburg, Cumb.Co.,Pa.

L. H. Miller, 'Thomasville, York $\mathrm{Cu}$., Pa.

S. D. Estep, Millwood. Clarke ('o., Va.

Fergerson \& Hutter, Lynchburg, Va.

Col. John D. Holt, Lynchburg, Va.

R. S. Mitchell, Ruffin, N. C.

W. V. Moore, Hamilton, Loudon Co., Va.

Suter \& Dold. Harrisonburg, Va.

E. Walton, Alexandria, Va.

Staver Buckeye Combined Mill and Power, 


\section{Vertical French Burrs Mill.}

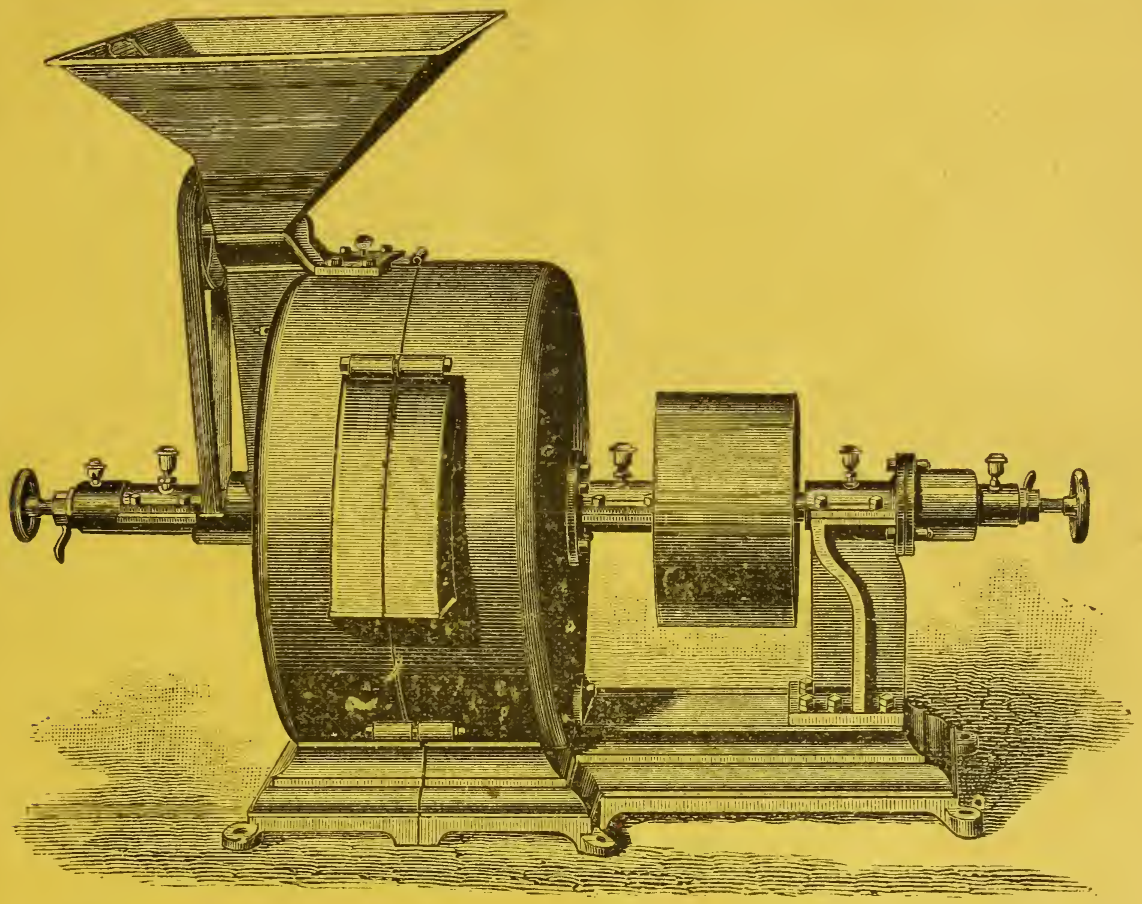

Waldron \& Sprout, Muncy, Pa., Manufacturers of the Celebrated Vertical French Burr Mills, suitable for Grain or any material that can be ground on a mill, also Manufacturers of Buckwheat Separators, Scourers, Buckwheat Shuckers, Round Reels, Scralpers, Corn Ear Crushers, Corn Meal Bolts and General Mill Machinery.

It will pay you to write for Catalogue and Prices before purchasing elsewhere.

GRIFFITH, TURNER \& CO., GENERAL AGENTS. 


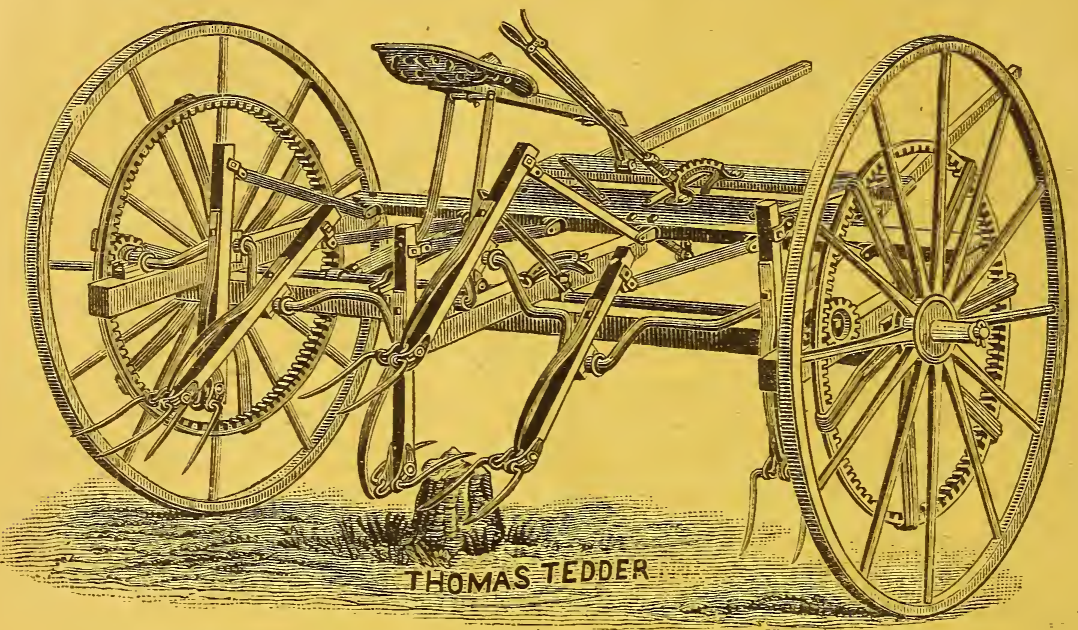

THE CELEBRATED THOMAS HAY TEDDER. Price, $\$ 40.00$

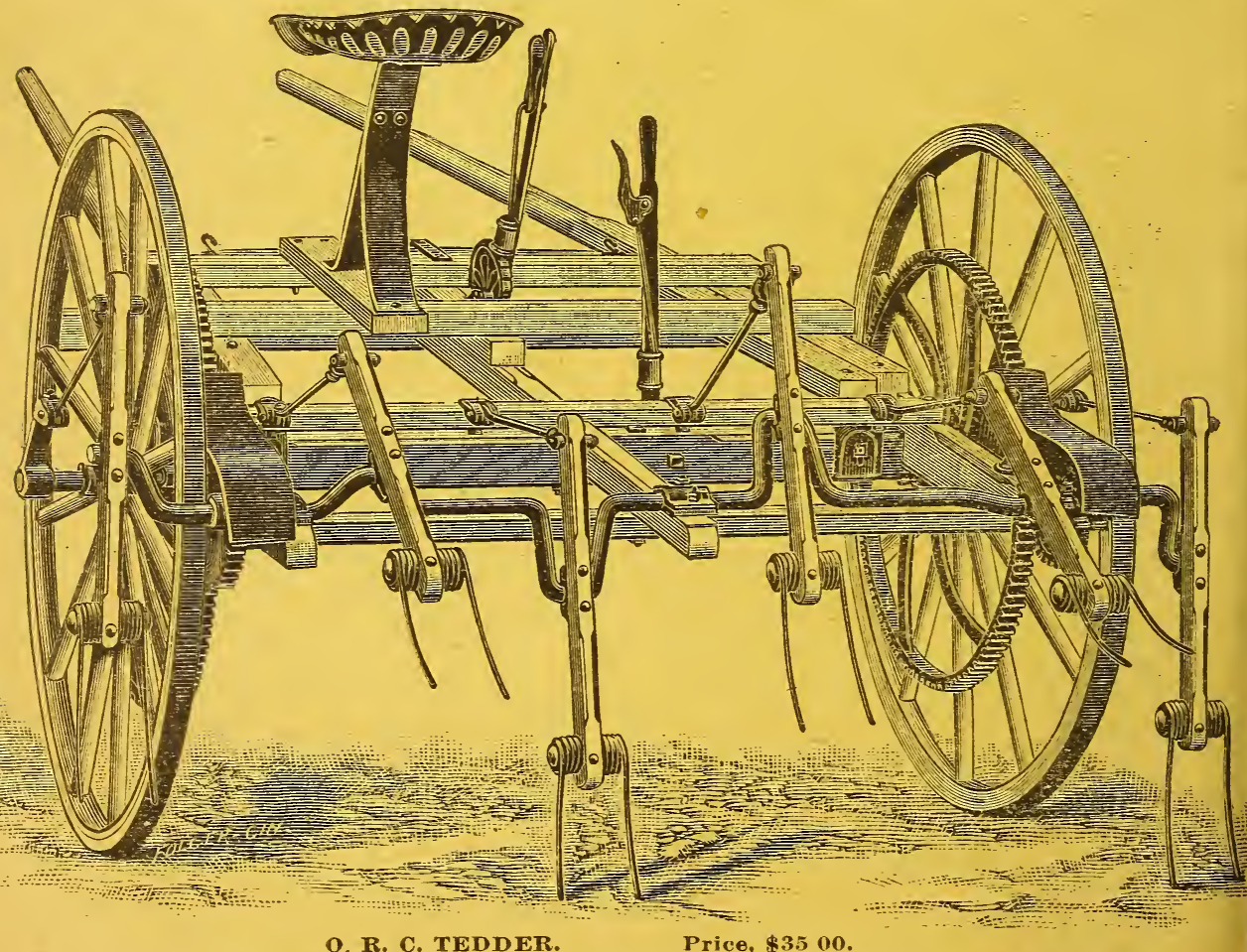

O. R. C. TEDDER.

Price, $\$ 3500$

With Combination'Shafts and Tongue; with Outside Fork and Shields over Gearing. 


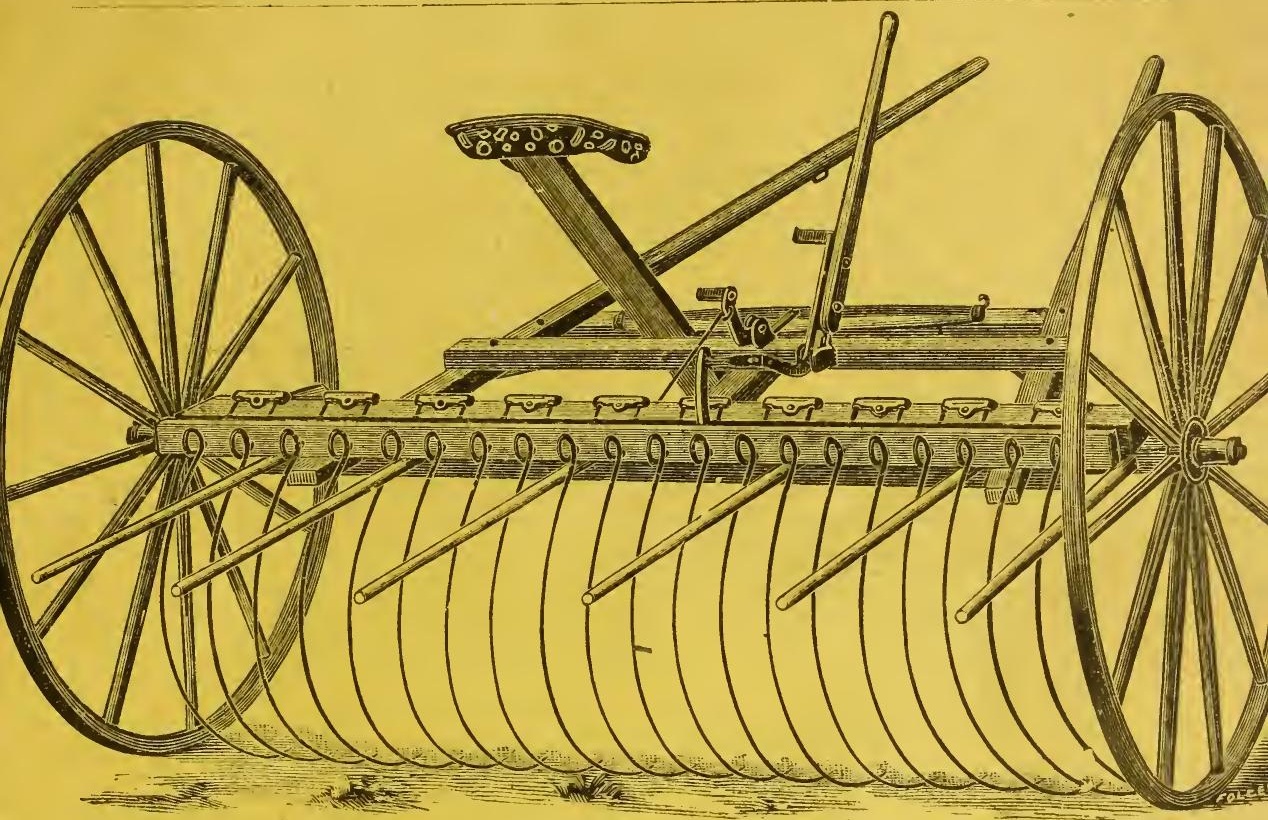

Above Cut represents the "GAZELLE," one of the best Self-Dump Rakes made.

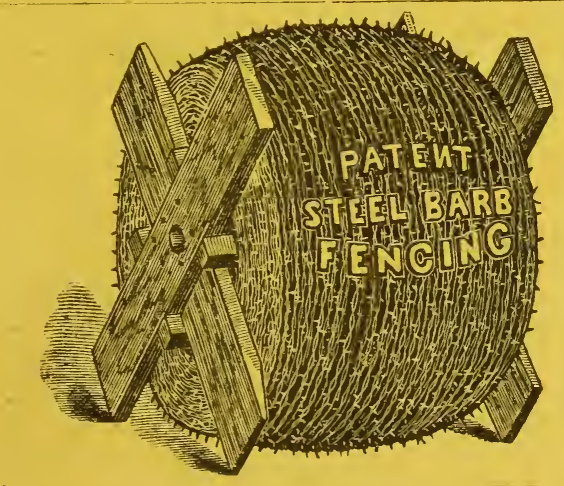

\section{PRICES OF RAKES.}

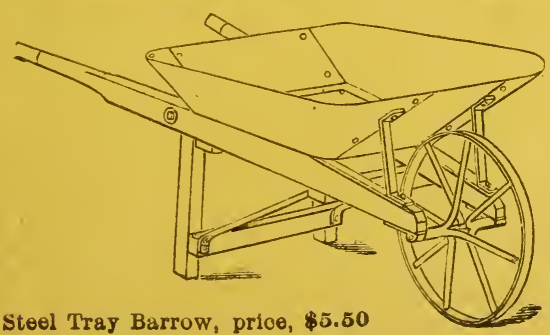

GAZELLE, - - $\quad$ - $\$ 25.00$

THOMAS RAKE, - 25.00

THOMAS IMPERIA L, 23.00

ROYAL SELF-DUMP, 25.00

VICTOR SELF-DUNP, 20.00

DAYTON HAND-DUMP, 20.00

ADVANCE HA N D-DUMP,15.00

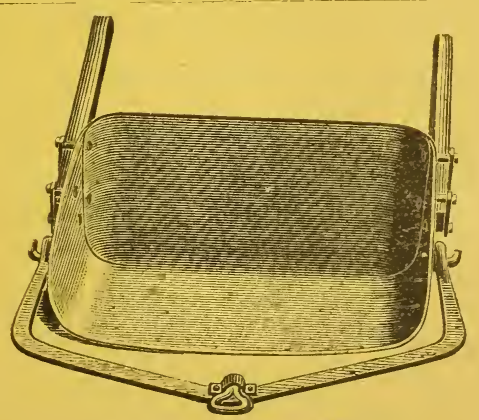

Steol Scraper, price, $\$ 8.00$. 


\section{DOCTOR BAIIFY Ensilage and Dry Forage Cutters.}

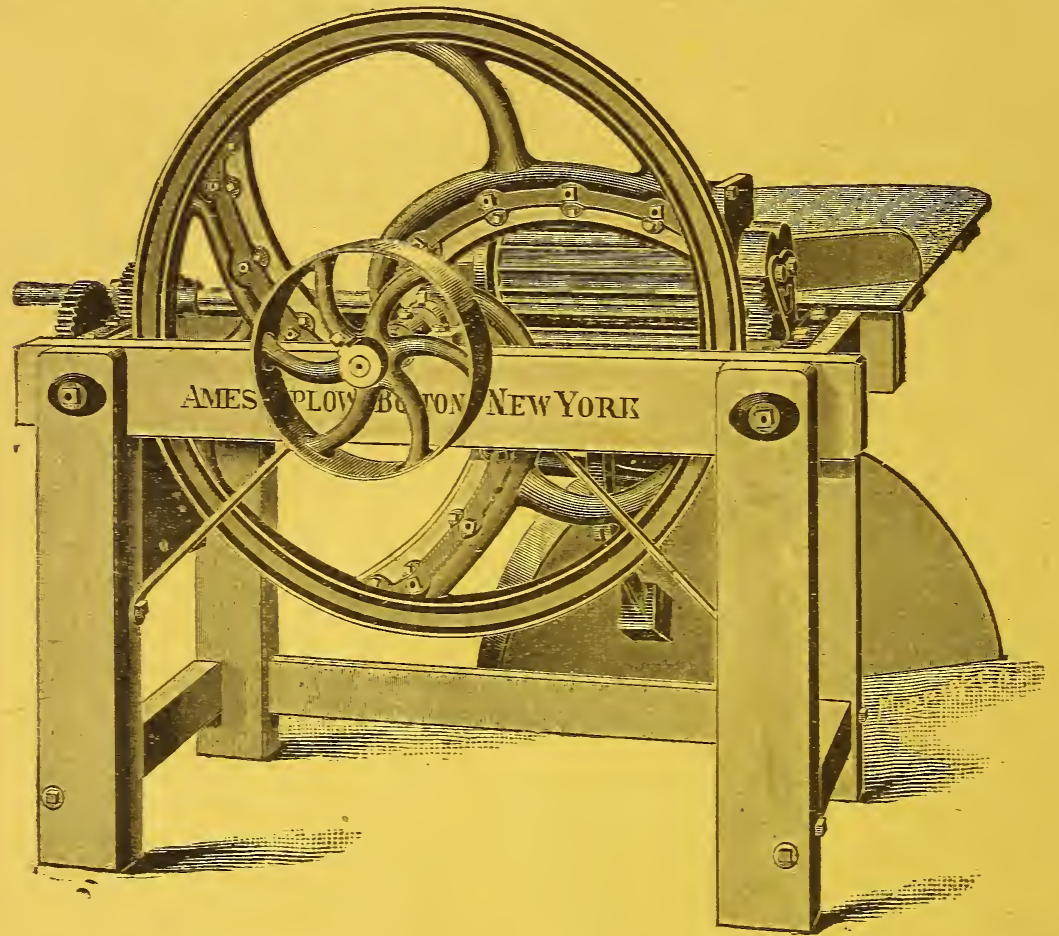

The Dr. Bailey Ensilage Cutters have many advantages possessed by no other Ensilage machine or cutter. Strength, durability, simplicity and rapidity of work are among the qualifications. They are giving entire satisfaction, and the ever increasing demand shows their great popularity. Ife herewith illustrate and describe in part only the advantages which can be claimed by no other cutter made.

There are six sizes. The size with ro-inch knives (illustrated on a following page) is for hand use; the I2-inch machine is for use by hand or horse power, the fourteen inch machine is for one-horse power, while with a one-horse power the I6inch machine (illustrated above) will cut much more than any cutter having convex knives.

Upon a careful test at "Winning Farm," the Doctor Bailey 20-inch machine cut green corn fodder at the rate of seren tons per hour, $3-8$ of an inch long, and at the rate of 15 tons per hour, 3-4 of an inch long.

The I2, I4, I 6 and 20 -inch machines cut ten different lengths-3/8, I/2, 3/4, $7 / 8, I, I 1 / 4$, $I \frac{1}{2}, I 3 / 4,2$ and $21 / 2$ inches. The IO-inch machine cuts four different lengths- $3 / 8, I, I \frac{1}{2}$, and $23 / 8$ inches.

\section{Prices :}

$9-$ inch,$\ldots \ldots \ldots \ldots \ldots \$ 28.00 \mid$ I2-inch,$\ldots \ldots \ldots \ldots \ldots \$ 55.00 \mid$ I6-inch $\ldots \ldots \ldots \ldots \ldots \$ 95.00$ I0 " ........... 35.00 I4 " .......... $75.00 \mid 20$ "6 ......... I 20.00 


\section{DOOTOR BAIIFY}

\section{Ensilage and Dry Forage Cutters. \\ I0 Inch Machine, for Hand Use.}

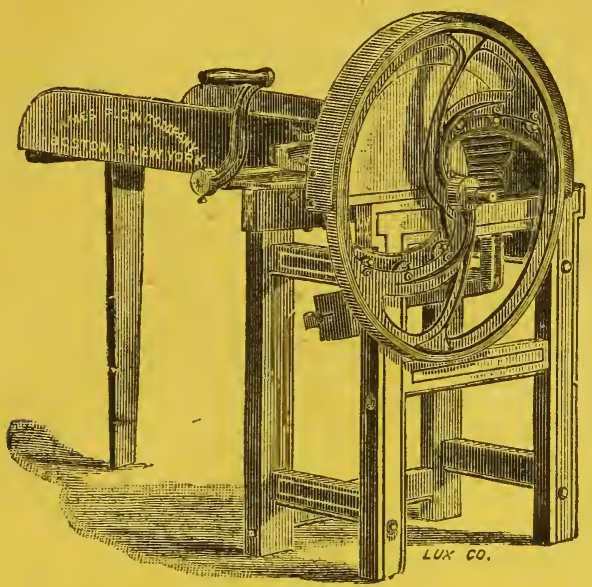

Joshua Regester, Baltimore, Md.

Gen'l Geo. S. Brown.

Powhatan Railroad Co.

McAfee Bros.,

F. Fribee,

Jesse Tyson.

Baltimore Chrome Works "

John Gill,

Theo. Mottu,

Samuel H. Tagart,

T. Alex. Seth,

German H. Hunt,

J. Q. A. Holloway

Walter Garland,

Samuel Messersmith,

Miss Mary Garrett,

Central R. R. Co.,

Christian Lipps,

s. C. Lee \& sons. for Champion Harvesting Machinery

John Crowther, Texas, Baltimore Co.

R. F. Caples, Cockeysville, ":

August Hook, " "

Z. Poteet,

J. M. Mecomas, White Hall,

Mrs. Mary E. Galloway, Timonium, Balto. Co.

Mrs. M. A. Worsley, liders. Baltimore Co.

Mrs. Ir, stevenson,

re $\mathrm{Co}$

Mrs. M. Worthington, Glyndon,

Michael Fringer, Pikesville,

Wm. Burnham,

Frank Sanderson,

Arthur Rich,

E. Cowling, Brooklandville,

Johu Hillen, Rosedale,

Martin L. Jean, Rockdale,

Dr. H. F. Ware, North Branch,

Sam'l M. Rankin, Long Green.

Fred. VonKapff, Govanstown,

S. N. Trump, Rossville,

J. M. Anderson, Phœenix, Md.

Cochran-Oler Ice Co., Balto., Md.

Charles I'. Cockey, Pikesville, Baltimore Co

Miss Annie D. Taylor, Govanstown,

J. K. Geise, Butler, Baltimore Co.
One of the best and most satisfactory Hand-Power Cutters ever offered to the trade. We give you names of a few

\section{OF THE MANY}

Who are using both hand and power Cutters, and to whom we refer anyone who wants to purchase.

James Milling, Rossville, Baltimore Co. Charles Brooks, Belfast,

Notre Dame Academy,

Mount Hope Retreat,

J. F. Lowekamp, Jessups, A. A. Co.

David Hanway, Bel Air, Harford Co.

Garrett Amos, Falston,

J as. Twning, Upper Crossroads,

A. B. Hollingsworth, Wilna,

L. B. Robinson, Jerusalem Mills, ".

C. C. Kinsey, Pilesville,

Jarnes A. Wiles, A berdeen,

James Smith

Isaac Amos, Emmerton,

E. A. Talbott, Ellicott City, Howard Co.

St. Charles College,

A. V. Thomas,

Christian Hanson,

E. R. Dennis,

E. G. Selby, Lisbon

Rev. E. E. Shipley, Cooksville,

James H. Hobbs,

John Patrick, Lisbon,

C. A. Ware,

Geo. Wm. Smith, Frederick, Md

E. Swomley, New Market, Frederick Co

Outerbridge Horsey.

C. M. Lewis, Walkersville,

J. H. Gassaway, Germantown, Mont. Co. Col. Jas. A. Boyd, Boyds,

Geo. W. Devilbiss, New Windsor, Carroll Co. Granville s. Haines, Union Bridge,

H. F. Caylor

Geo. P. Buckey, Jr.

L. Scott Mercier, Woodbine,

Chas. E. Coffin, Muirkirk, Prince George's Co.

C. R. Paxton, Leesburg, Va.

C. Billups, Norfolk, Va.

Wm. H. May \& Son, Alexandria, Va.

S. D. Estep, Millwood, Va.

N. O. Allen, Summit Point, W. Va.

S. M. Anderson, New Freedom, $\mathrm{Pa}$. 


\section{Celebrated Ross Cutters and Carriers.}

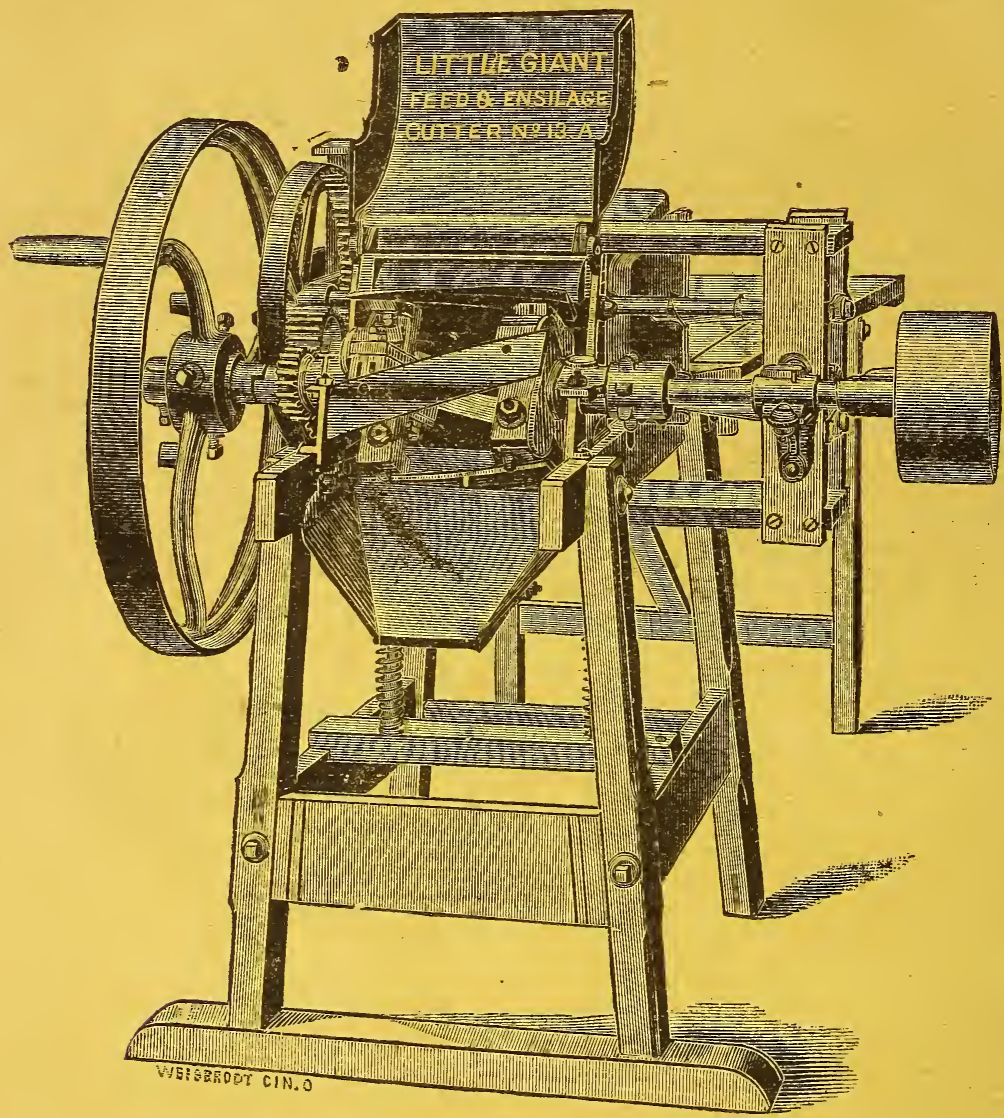

The above Cut shows the Power Cutter.

Seme of the characteristics of this popular machine are, first:-The Upward Cut, whereby the knife shaft rests naturally on its bearings, and thus avoids that jarring of other machines, as the Downward Cut lifts the shaft out of the box.

By the Upward Cut the edges of the knives and the cutting plate are both in full view, so that after sharpening and grinding. the knives can be adjusted accurately and easily, whereas with the Downward Cut, the edges of the knives and cutting plate are obscured by the back edge and curve of the knife.

By a perfect arrangement the feeding rollers can open either parallel or obliquely, and at the same time retain all parts in perfect position; and by opening obliquely will feed heavily on one side and less on the other; they are self-feeding and cannot clog or stop.

By a peculiar device the fly wheel is fastened securely by a key and screw, but so arranged that by loosening the set screw, it is quickly and easily removed without touching the key.

The length of cut can be quickly and easily changed, every piece being plainly marked, so that mistakes are impossible. 


\section{THE No. 9 A, HAND-POWER CUTTER}

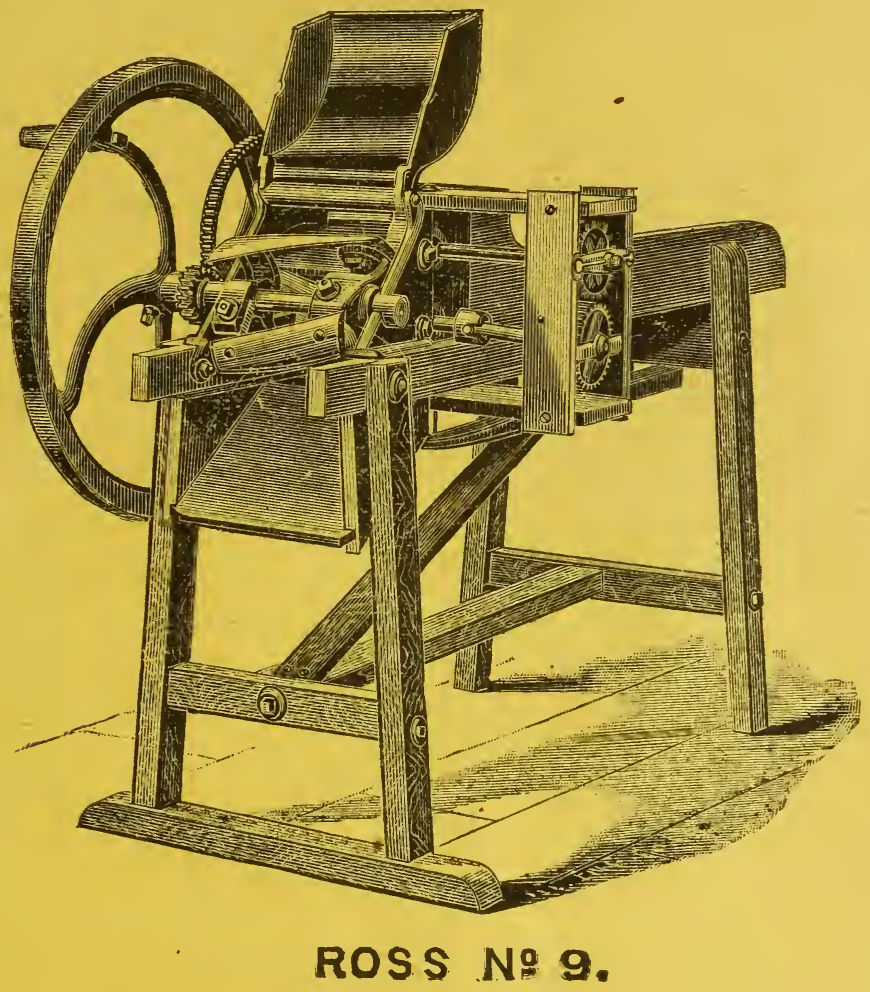

This is the famous hand-power Cutter of the Ross principle; it is very heavy, strong and durable, simple in construction; does not get out of order, and the knives retain their edge after long periods of continuous usage. "It has the Upward Cut, self-feeding rocking rollers and chilled cutting plates; is suitable for every purpose, in the city or on the farm, and cuts every kind of material with ease and in a most perfect manner.

\section{Prices of Ross Cutter's :}

Lever $\$ 5.00$ net.

No. 7, Cylinder Hand Cutter, - _ _ _ _ _ _ _ _ _

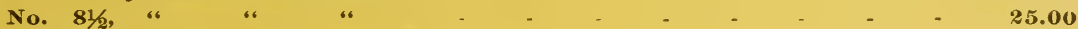

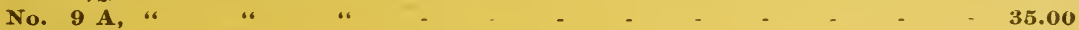

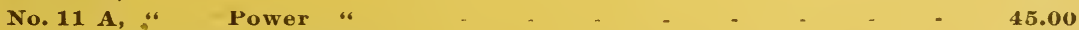

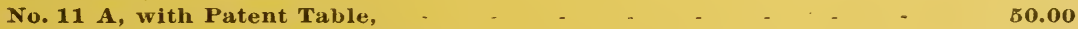

No. 13 A, Cylinder Power Cutter, - _ _ _ _ - _ _ - $\quad$ - $\quad$ - 6.00

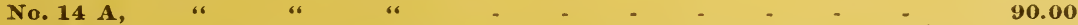

From prices on Cylinder Cutters we make a discount of 20 per cunt. to the Farmers, the price on Lever Cutter is net. 


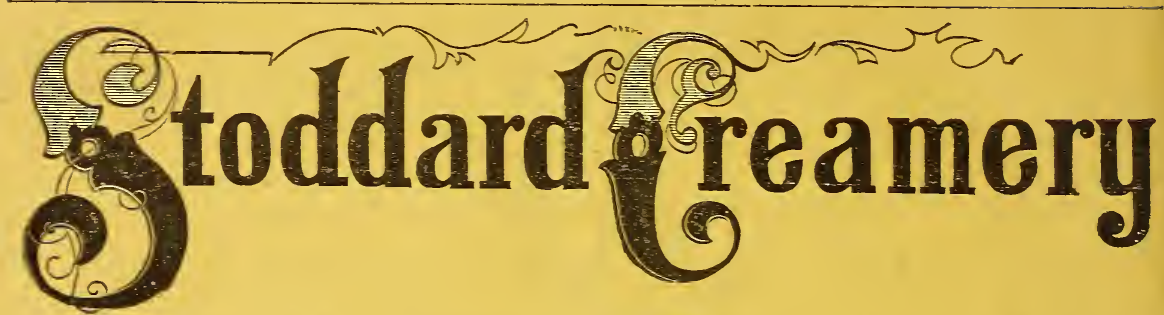

\section{WITH SURFACE SKIMMI
With or Without Special Refrigerator.}

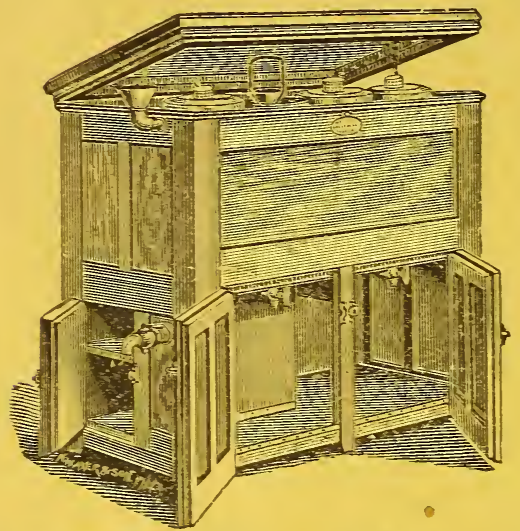

THOROUGH IN CONSTRUCTION. SIMPLE IN OPERATION. $=$ ACCURATE IN ITS WOREING.

Combining more points of merit than ans other cream-raising apparatus on the market.

tuaroid Sediment in Cream by using the Stoddard Creamery, which is the only one provided with a Perfect Working Surface Skimmer.

Made in sizes to suit any Dairy from One to Fifty Cows. Used with or without Ice, and adapted to summer or Winter Dairying.

DON'T BUY A POORLY MADE CHCRY BECAUSE IT'S CHEAP. BUY THE BEST.

\section{THE STODDARD CHURN,}

The Most Perfect on the market. as attested by Sales.

MADE IN 9 SIZES FOR DAIRY or FACTORY.

Wrth or Wrrhoct Pelless.

The principle is Concussion and not Friction. Has no Floats or Paddles. Corer Remored Instantly. Has Best Fastener Made. Send for Prices.

WE CAY FURNISH FULL LINE OF DAIRY SCPPLIES.

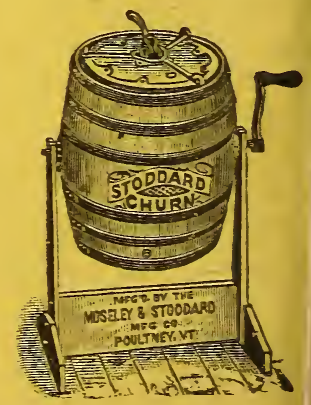




\section{THE AMERICAN ROUND WASHER,}

IS THE BEST WASHER MADE.

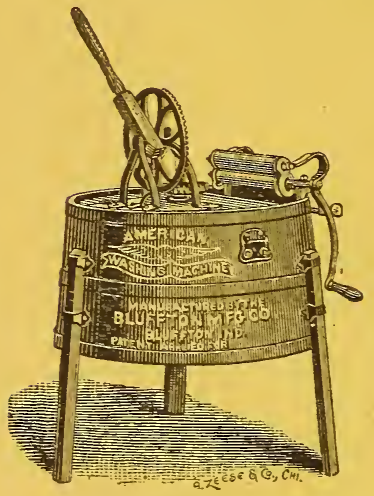

Actual trial has proven beyond a doubt that it will

WASH CLEANER, QUICKER,

WITH MORE EASE

AND LESS INJURY

To the clothes than any machine now in use.

\section{PRICE, \$8.00.}

We claim that the American Round Washing Machine is the best washer made, and the price is within the reach of all who use a washing machine. We, therefore, invite the attention of dealers, and the public at large to our American Round Washer. We are aware that there is a great deal of prejudice and opposition to our cause, from the fact that so many washers have proven worthless Our machine is novel in its construction, being a truncated cone form, with the larger dimensions down. This is to prevent the clothes from packing, giving the water free access through the fabric, and washes in less time and with less work than the square box. This, a thorough investigation has proven beyond a doubt. Also, that a tub made of clean pine, with heavy iron hoops, is far superior to a box, and will last much longer. Not so liable to leak. We use only thoroughly seasoned timber in our machines.

Our prices are lower than for any other washer made, with the same amount of labor to make it. It has come to stay. IVe have found that many washing machines now manufactured are so constructed that wringers cannot be used on them; or, if so, only a certain kind. On the American Round Washer you can use any kind of a Wringer. See cut. Please call at our place of business and get an American Round Washing Machine, give it a fair trial, following directions which are on each machine, and if you do not think it worth more than it costs, return it and get your-money.

THE BLUFFTON CLOTHES-BAR.

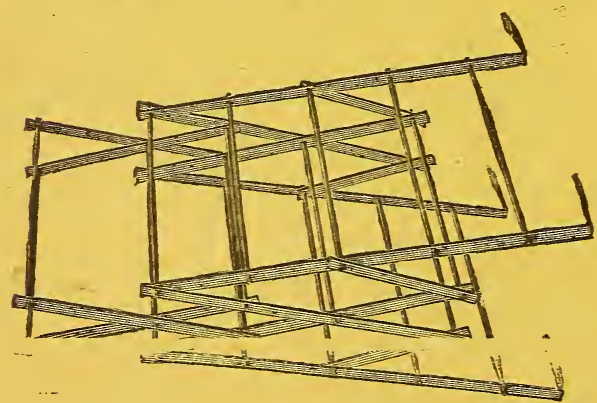

57 feet of Hanging Room. Price, $\$ 1.00$.
The Best Folding Ironing-Board in Use.

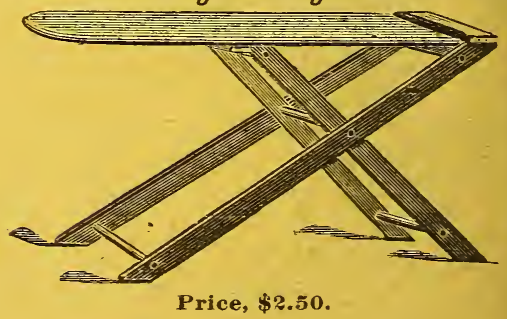

SUPERIOR WRINGERS

Always in stock. 


\section{The Howari Patent Mdjustistabie Borster spring.}

IMPROVED PATENT, OCT. 19, I888.

25,000 sets in use. Their success established throughout the United States. Examine the cuts and note the principle of its construction. The center springs, for heavy use, are the old reliable elliptic, oil tempered steel, which prevents any strain upon the bolster stakes. They are complete as sold and require no alteration of the wagon in applying them to bolsters. Give them a trial, they will prove to be the best investment you ever made. Springs warranted to carry their full capacity.
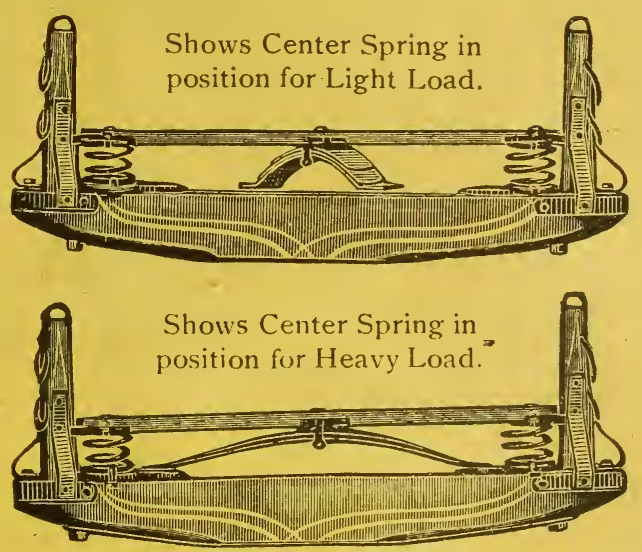

\section{PIICE IIST.}

To carry 6000 lbs., \$1 \$2.00

$\begin{array}{rrrr}\text { “ } & 5000 & \text { “ } & 11.00 \\ \text { “ } & 4000 & \text { 6 } & 10.00 \\ & 3000 & 6 & 9.00\end{array}$

To carry 2500 llos., \$8.51) -

$\begin{array}{llll}“ & 2000 & \cdots & 8.00 \\ \because \quad 1.500 & 6 & 7.00\end{array}$

\section{Dutton Mower Knife Grinder.}

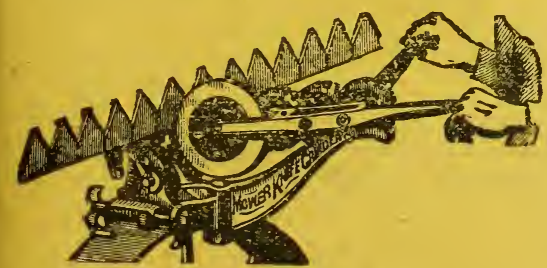

The Wheel is made of corundun and is hollow. Fill the Wheel with water before using. When in motion the water is forced ont through the wheel, which is porous. This keeps the knife cool. No gumming; no loss of temper, either on the part of the knife or its owner. Price, \$6.00.

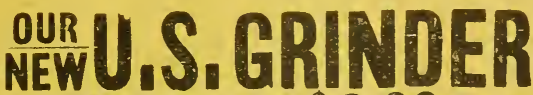

The Most Com-Price $\$ 6,00$ plete MOWING MACHINE KNIFE

S M A L L. L I G H T Weighs only 13 los. Can carried into the field and attached to Mowing Machine Wheel.

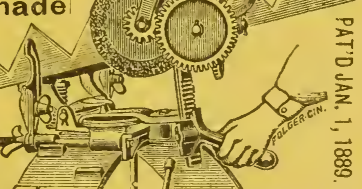
Send for New Circular, with full description FREE. 


\section{BODT CART, No. A $z$}

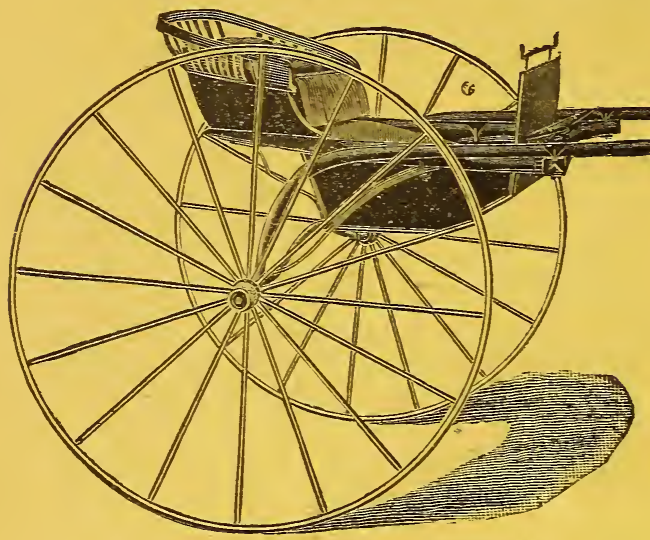

Is one of the handsomest vehicles of its kind ever put on the market, and is bound to sell on sight.

Has compartment under the seat for parcel stowage, and has a handsome, roomy body and wood dash with line rail. The body and dash are finished in the natural wood or painted black, and in contrast with the finished gear make a very handsome job. We furnish a cushion with this job. A very stylish and finely finished cart. Built for two passengers.

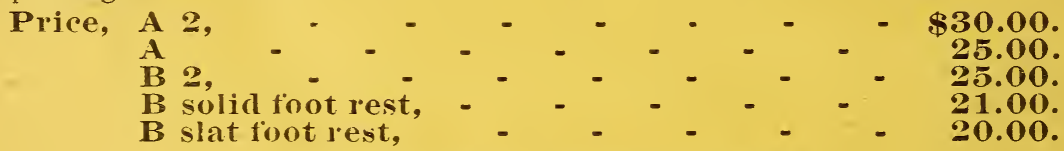

\section{FEARIV CARTS.}

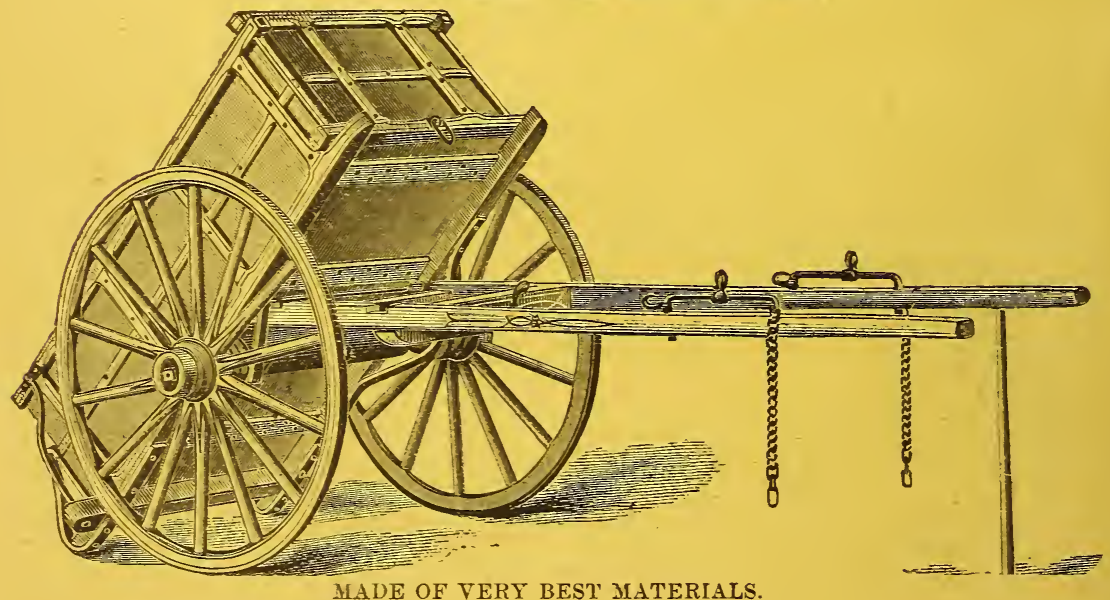

In use at Steelton Steel Works, Sparrow's Point, and by many farmers and contractors. Prices of different sizes and styles on application. 


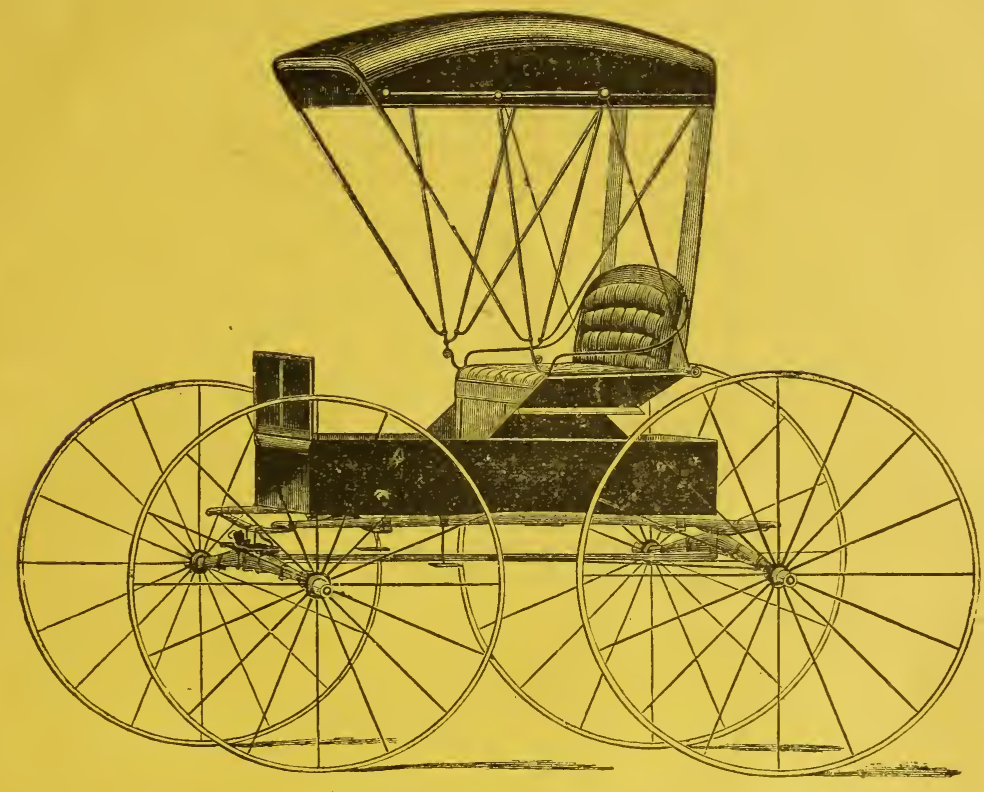

BREWSTER SIDE-BAR.

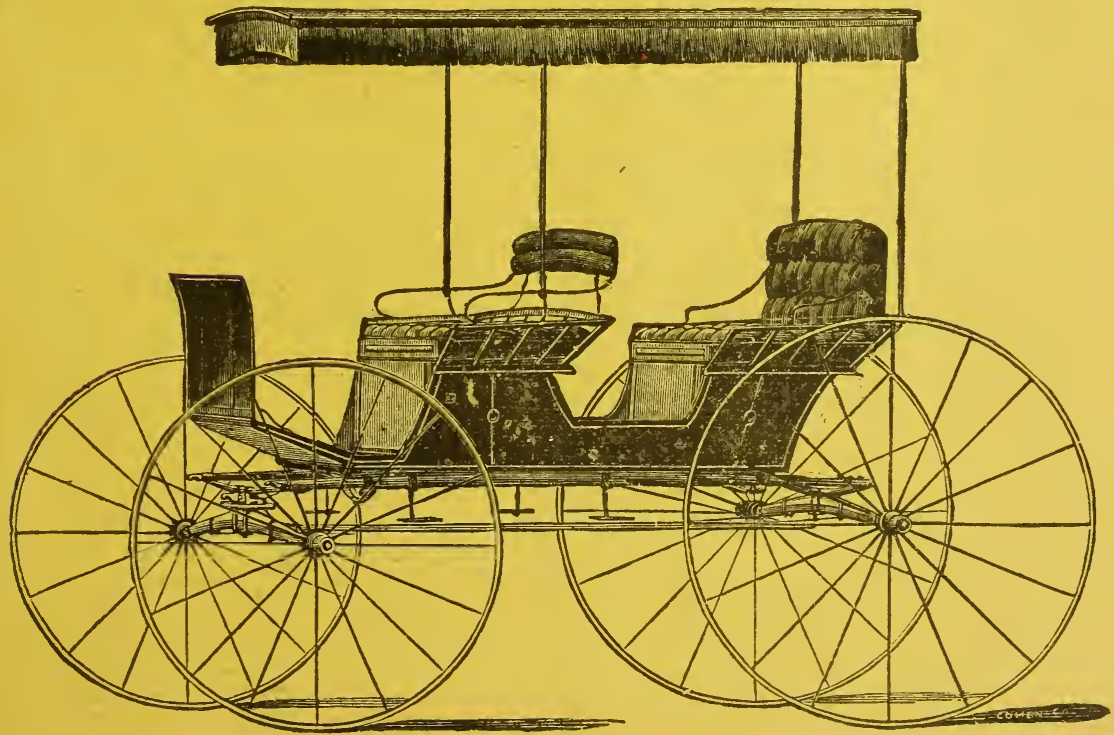

SIDE-BAR CANOPY SURREY. 


\section{One and Two Horse Union Ry. Horse Powers.}

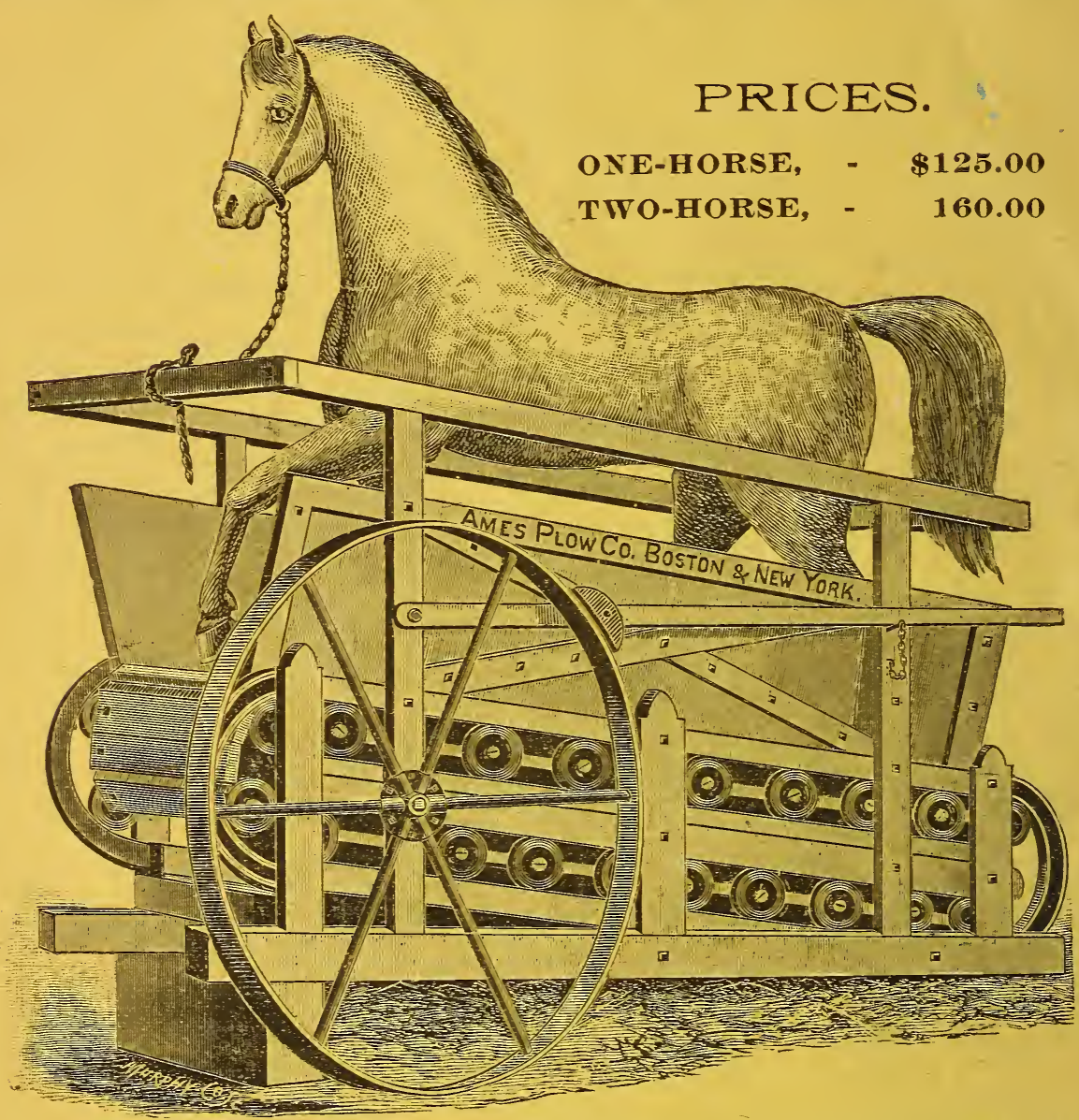

The wood frame work is constructed similar to most of the tread or endless chain powers in use but more durable in all its parts, and the arrangement of the running sear is rery much better. The band wheel is readily changed from one side of the machine to the other.

Their adrantages orer other horse powers give satisfactory results as follows :

1st. It is the most durable of any horse power made. 2nd. It requires the least elevation of anr to obtain a gifen amount of speed. 3rd. These Powers are wider and longer than any other, givany ing ample room for the horses to walk with ease and safety. and The platform chain mores with a perfectly smooth and free motion. 6th. All the pivots, boxes, wheels and axles are chill hardened and smooth, thus causing little friction and adding greatly to the durability. 7 th. The power is applied both at the top and bottom of driving gear; by greatly to the dinachine with great force. 8 th. There is no strain on the chain in passing the end tracks. 9th. There are no cross rods between the treads to get bent out of place and add to the weight of the moving platform.

In short. these are by far the most satisfactory machines for the purpose in the market, and they bave received first premiums at all the fairs where they have been exhibited. 


\section{SUPERIOR GRAIN DRILLS,}

THE IBFST PIAIN AND FERTILIZER DRIYLS IN THE WOKYD.

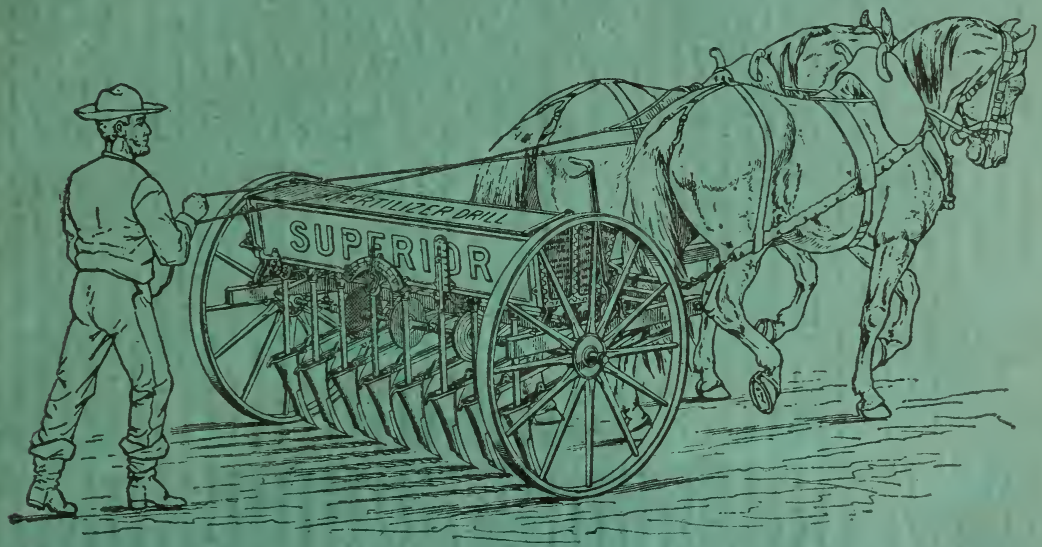

Made by the SUPERIOR DRILL CO, Springfield, Ohio,

\section{THE BEST}

\section{sipring Hoes.}

Hoe Pressure Attachment.

Grass Seed Sower.

Hoe Shifter.

\section{TEI BEST}

Hoe with Reversible Steel Point. Material used in its Manufacture. Finished Drill in the Market.

The Only Enam'ld Fert'lur Distribtrs.

Will sow Wheat, Rye, Oats, Coru, Beans, Peas, Buckwheat, Flaxseed and all kinds of Grass Seed better than any other Drill.

Have Force-Feed Distributors for sowing Grain, Fertilizer and Grass Seed.

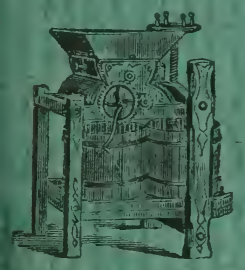

\section{IMPROVED BUCKEYE \& CHAMPION * Cider * Fills, *} THE BEST AND LIGHTEST-RUNNING MILLS IN THE MARKET.

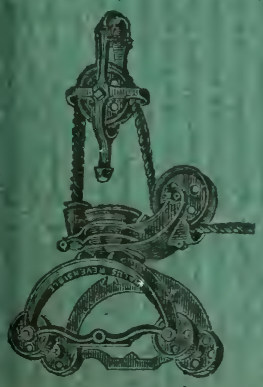

\section{HaLL'S REVERSBBLE HaY GaRliER.}

For Wood or Steel Tracks.

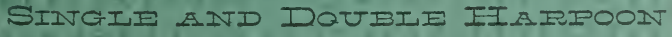 STIFELIS HAY FORKS}

Of Best Quality and Finish.

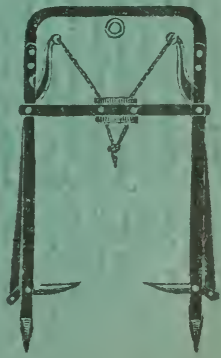




\section{THE BROWN WAGON.}

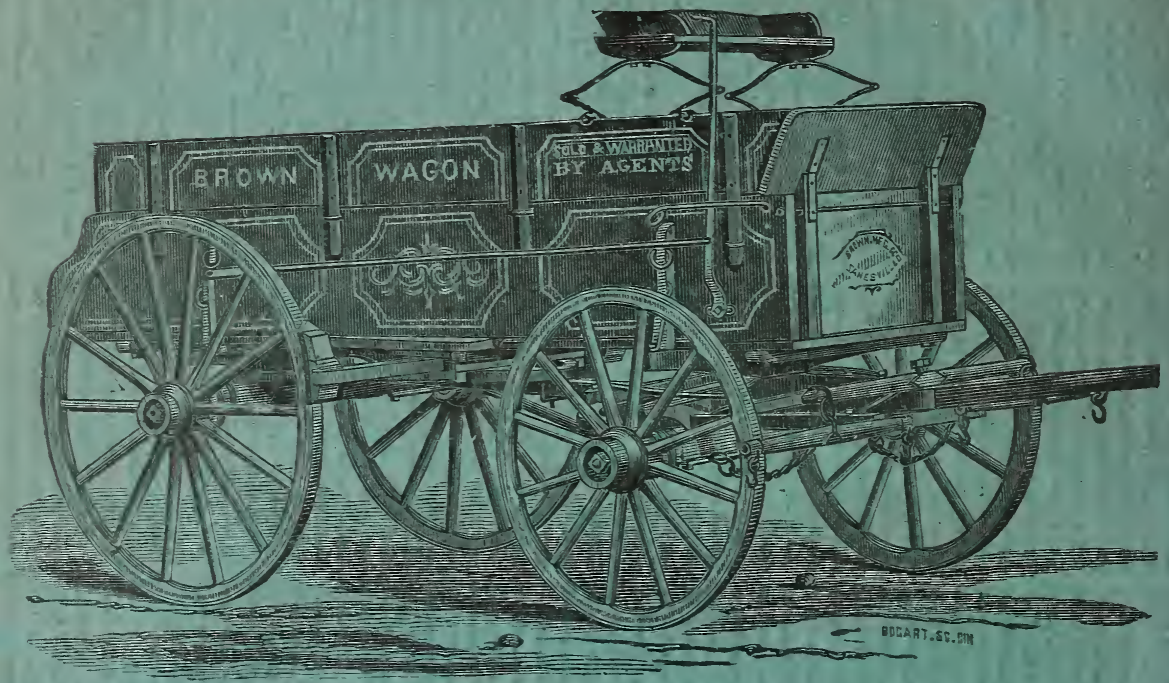

\section{REASONS FOR ITS SUPERIORITY :}

tight.

Oil Boiled Fellows-shutting out all moisture, preventing rot and keeping tires

Stay Chains, with springs to control the wheels, and destroys largely the switching of the tongue.

When either holding the wagon down grade, or backing a loaded wagon, the Tongue Chains are unyielding, stiff and damaging to both team and harness. While the Tongue Chains are too rigid, ENDWISE, they lack CONTROL from the side jerking of the tongue. This side jerking allows the tongue to whip the horses' legs, and the travel of the wagon is hindered by the unsteady motion of the tongue.

\section{A SUCCESSFUL REMEDY.}

To overcome the above objections in Tongue Chains, as commonly used, we have applied Coil Springs to ease the DRAFT on the team's neck, when the chains are forced to control the tongue or HOLD BACK.

We also add a Branch Chain to each Tongue Chain. The Branch Chain is to destroy, as far as possible, the side jerking, and to protect the horses from the whipPING motion of the tongue. The CoIL.SPRINGS yield to either the pull of the CHAIN, or BRANCH, saving the team at all times from the sudden jerking of the tongue; protecting both horses and harness. The BRANCH CHaINS have the tendency to prevent side motion of the tongue-same as neck yoke, but less cramping for the horseswhile the Coil Springs supply the place of the vibrating of the neck yoke to ease the team's necks. Only wagon with Yielding Tongue Chains with CHECK BRANCHES.

\section{STEIN AND AXLE DIFFERENT FROM ALL OTHERS.}

Our Extension Shoe Skein is one of the greatest improrements on wagons during the last fifty years; as it protects the axle as well as the skein, allowing the axle to be made of less material. The shoe of the skein supports the axle where it has the greatest load to bear, and is superior to the Steel Skein, as it allows a greater quantity of the axle to enter the shoe of the skein.

The Skein is so chilled on its face, and will wear longer than a steel skein. The steel skein has no temper in it, and is as soft as iron as it is required to be welded to
make it. 